\title{
BIBLIOGRAPHY OF REGIONAL AQUIFER-SYSTEM ANALYSIS PROGRAM OF THE U.S. GEOLOGICAL SURVEY, 1978-91
}

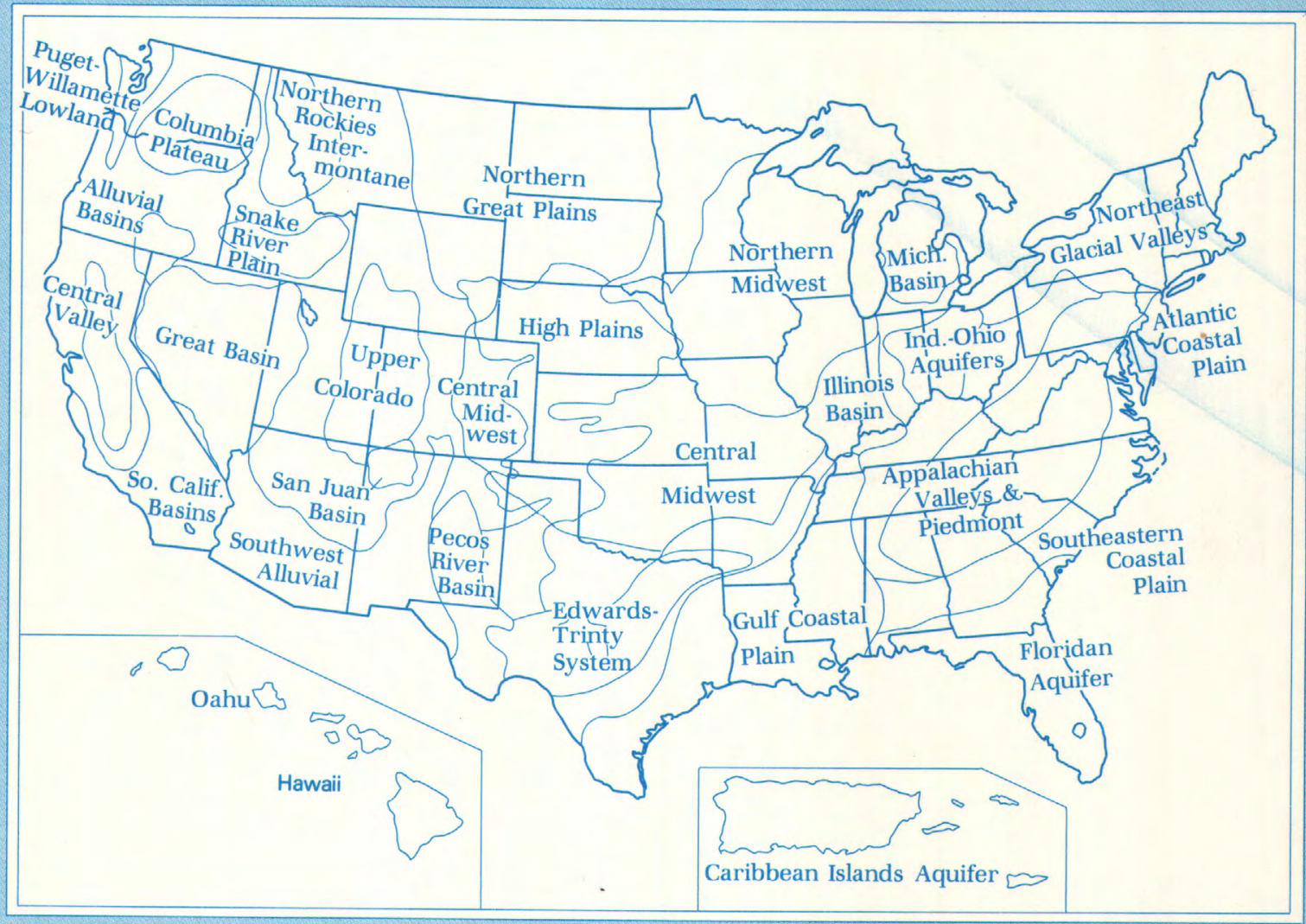

U.S. Geological Survey

Water-Resources Investigations Report 91-4122 

BILIOGRAPHY OF REGIONAL AQUIFER-SYSTEM ANALYSIS PROGRAM OF THE U.S. GEOLOGICAL SURVEY, 1978-91

By Ren Jen Sun and John B. Weeks

U.S. Geological Survey

Water-Resources Investigations Report 91-4122 
U.S. DEPARTMENT OF THE INTERIOR

MANUEL LUJAN, JR., Secretary

\section{U.S. GEOLOGICAL SURVEY}

Dallas L. Peck, Director

For additonal information write to:

RASA Program Coordinator

Water Resources Divison

U.S. Geological Survey

MS 411 National Center

12201 Sunrise Valley Drive

Reston, Virginia 22092
Copies of this report can be purchased from:

U.S. Geological Survey

Books and Open-File Reports Section Federal Center

Box 25425

Denver, Colorado 80225 


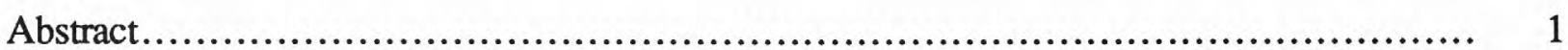

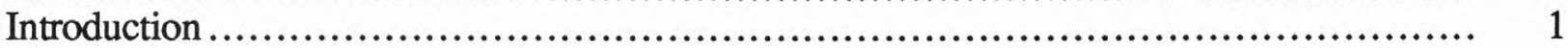

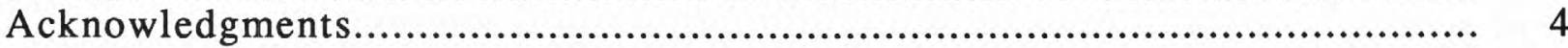

Fully completed regional aquifer-system analysis studies............................... 5

Floridan Aquifer System............................................................... 5

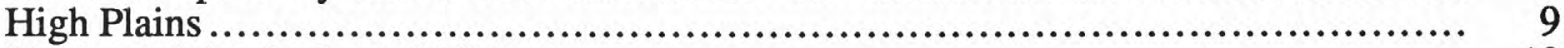

Northern Atlantic Coastal Plain ............................................................. 18

Northern Great Plains ................................................................ 21

Northern Midwest ..................................................................... 28

Southeastern Coastal Plain.................................................................... 31

Completed regional aquifer-system analysis studies for which additional reports are in preparation or in review

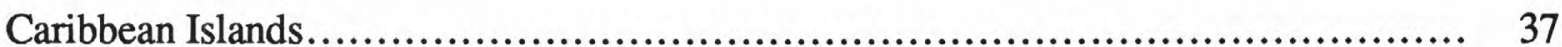

Central Valley, California......................................................... 39

Central Midwest............................................................................ 45

Columbia Plateau, Washington, Oregon, and Idaho ............................... 50

Great Basin, Nevada and Utah.................................................. 53

Northeast Glacial Aquifers............................................................... 57

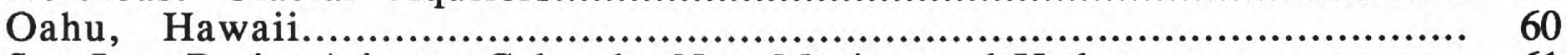

San Juan Basin, Arizona, Colorado, New Mexico, and Utah.................................... 61

Snake River Plain, Idaho ........................................................ 63

Southwest Alluvial Basins.................................................................... 67

Upper Colorado River Basin .................................................. 74

Ongoing regional aquifer-system analysis studies.............................................. 79

Appalachian Valleys and Piedmont ................................................ $\quad 79$

Edwards-Trinity Aquifer System, Arkansas, Oklahoma, and Texas .................... 80

Gulf Coastal Plain ................................................................... 82

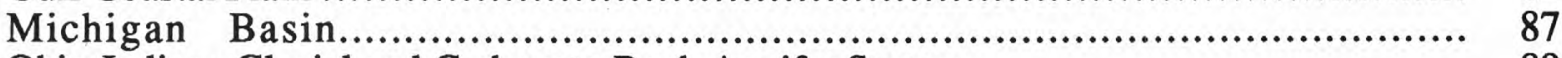

Ohio-Indiana Glacial and Carbonate-Rock Aquifer System .............................. 89

Puget-Willamette Lowland, Washington and Oregon .................................. 90

Southern California Basins .......................................................... 90

Ground Water Atlas of the United States ....................................... 91

\section{FIGURES}

1. Map showing locations of regional aquifer-system studies .......................... 2

2. Map showing States that are contained in each segment of the Ground Water Atlas of the United States. 


\section{CONVERSION FACTORS}

\section{Length}

inch (in)

foot $(\mathrm{ft})$

mile (mi)
25.4

0.3048

1.609

Area

square mile $\left(\mathrm{mi}^{2}\right)$

Volume

acre foot (acre-ft)

1,233

Flow

foot per year ( $\mathrm{ft} / \mathrm{yr})$

inch per year (in/yr)

cubic foot per second $\left(\mathrm{ft}^{3} / \mathrm{s}\right)$

gallon per minute (gal/min)

billion gallons per day (Bgal/d)

million gallons per day (Mgal/d)
0.3048

25.4

0.02832

0.063098

43.81

0.04381 millimeter (mm)

meter (m)

kilometer $(\mathrm{km})$ square kilometer $\left(\mathrm{km}^{2}\right)$

cubic meter $\left(\mathrm{m}^{3}\right)$

Sea level: In this report "sea level" refers to the National Geodetic Vertical Datum of 1929 (NGVD of 1929)--a geodetic datum derived from a general adjustment of the first-order level nets of both the United States and Canada, formerly called Sea Level Datum of 1929. 


\title{
Bibliography of Regional Aquifer-System Analysis Program of the U.S. Geological Survey, 1978-91
}

\author{
By Ren Jen Sun and John B. Weeks
}

\begin{abstract}
The Regional Aquifer-System Analysis (RASA) Program of the U.S. Geological Survey was initiated in 1978. The purpose of this program is to define the regional geohydrology and establish a framework of background information on geology, hydrology, and geochemistry of the Nation's important aquifer systems. This information is critically needed to develop an understanding of the Nation's major ground-water flow systems and to support better management of ground-water resources.

As of May 1991, 28 of the Nation's major aquifer systems have been identified for study under this program. Of these, 17 regional aquifer-system studies have been completed, and 8 studies are ongoing. Starting in 1988 , the program devoted part of its resources to compilation of a Nationwide ground-water atlas that presents a comprehensive summary of the Nation's major ground-water resources. The atlas, which is designed in a graphical format supported by descriptive text, will serve as a basic reference for the location, geography, geology, and hydrologic characteristics of the major aquifers in the Nation.
\end{abstract}

This bibliography lists the published 876 reports resulting from various studies of the program, from 1978 through May 1991. The list of reports for each study is placed after a brief description of that study.

\section{INTRODUCTION}

The U.S. Geological Survey initiated the Regional Aquifer-System Analysis (RASA) Program in 1978 in response to Federal and State needs for information to improve management of the Nation's ground-water resources. The objective of the RASA Program is to define the regional geohydrology and establish a framework of background information--geologic, hydrologic, and geochemical--that can be used for regional assessment of ground-water resources and in support of detailed local studies.

A total of 28 aquifer systems have been identified for study under the RASA Program (fig. 1). As of May 1991, studies of 25 aquifer systems are either ongoing or have been completed. Planned studies of three aquifer systems--the Pecos River Basin in New Mexico and Texas; the Alluvial Basins in Oregon, California, and Nevada; and the Illinois Basin in Illinois-have not yet begun. This report provides synopses of 24 regional aquifer systems and lists reports resulting from studies of each of these systems. The recently started Northern Rocky Mountains Intermontane Basins RASA study in Montana and Idaho has not reached the stage of report production as of May 1991, and therefore it is not included in this report.

Because of the critical need for a unified summary of ground-water information on a nationwide scale, compilation of a ground-water atlas of the United States was started in 1988 and is scheduled for completion by 1994. The compilation of the atlas uses RASA study results as the principal sources of information plus information obtained from other reports of the Geological Survey, various States and local agencies, and articles published in scientific journals. The atlas project is discussed in another section of this report.

The Geological Survey has a National Research Program (NRP) that conducts basic and problem-oriented research. Basic research explores the scientific processes that control the quantity and quality of the Nation's water resources. Problem-oriented research develops operational and interpretative methods useful for water-resources investigations inside and outside 


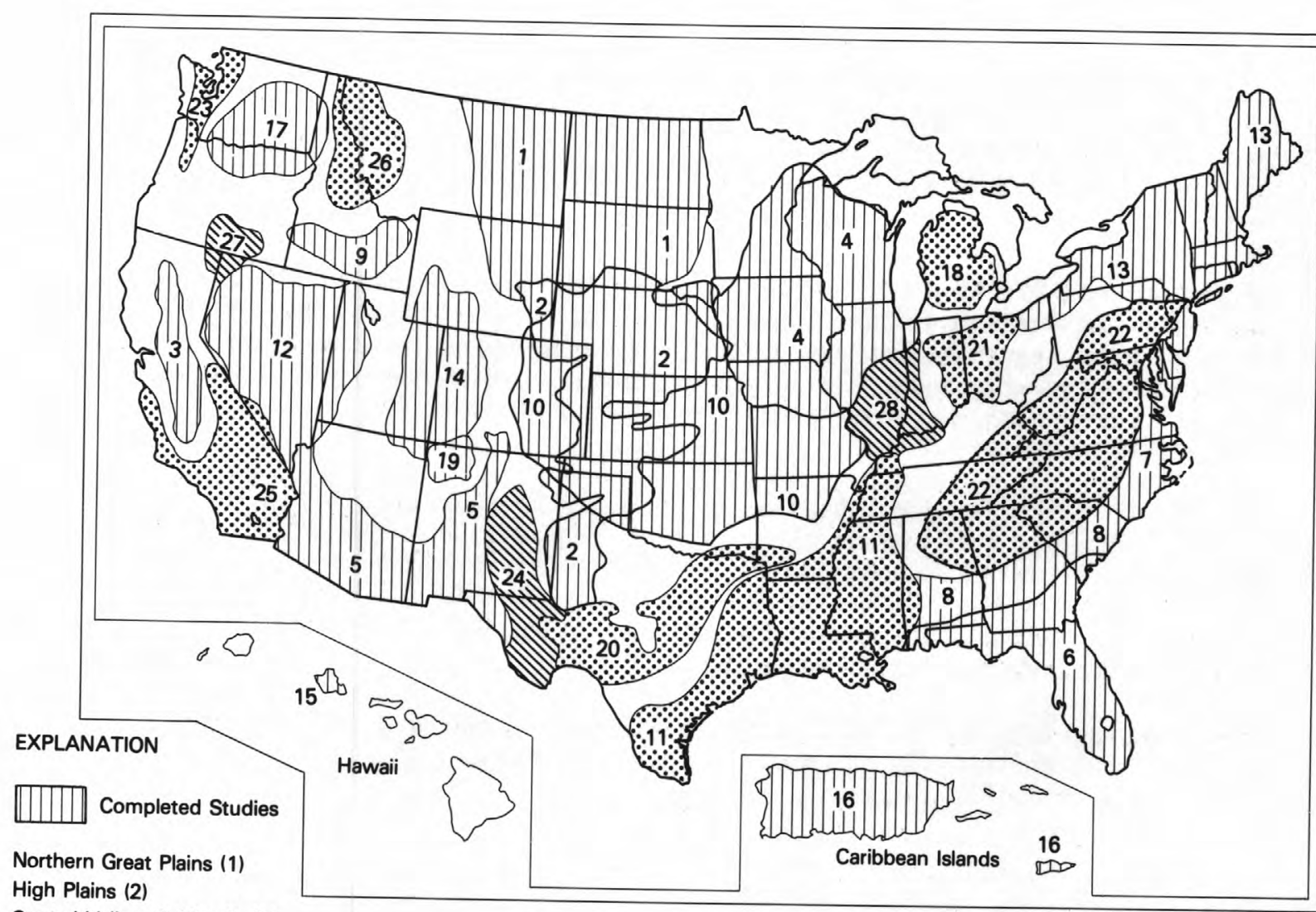

Central Valley, California (3)

Northern Midwest (4)

MAP NOT TO SCALE

Southwest alluvial basins (5)

Floridan Aquifer system (6)

Northern Atlantic Coastal Plain (7)

Southeastern Coastal Plain (8)

Snake River Plain (9)

Central Midwest (10)

Great Basin (12)

Northeast glacial aquifers (13)

Upper Colorado River Basin (14)

Oahu, Hawaii (15)

Caribbean Islands (16)

Columbia Plateau Basalt (17)

San Juan Basin (19)

\section{$\because \because 0^{\circ}$ Active Studies}

Gulf Coastal Plain (11)

Michigan Basin (18)

Edwards-Trinity aquifer system (20)

Ohio/Indiana carbonates and glacial deposits (21)

Appalachian Valleys and Piedmont (22)

Puget-Williamette Lowland (23)

Southern California basins (25)

Northern Rocky Mountains

Intermontane Basins (26)

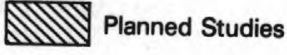

Pecos River Basin (24)

Alluvial basins, Oregon, Calif., Nev.(27) Illinois Basin (28)

Figure 1. Locations of regional aquifer-system studies 
of the Survey. The RASA Program has benefited from both the basic and problem-oriented research conducted through NRP; in return, the RASA Program has contributed funds to NRP each year. This contribution is used for research in all phases of the hydrologic cycle and is not limited to studies that are directly related to the RASA Program. For this reason, the reports resulting from the National Research Program funded by the RASA Program, are excluded from this report.

This bibliography contains three parts. The first part lists the studies that have been fully completed except for one or two studies that still have one or two reports in review. The second part lists those studies that the investigation efforts have been fully completed but the scheduled reports in addition to those listed in this report are still in preparation or in review. The third part lists currently (1991) ongoing studies.

Upon completion of each study, a series of U.S. Geological Survey Professional Papers are published to summarize and synthesize the results of that study. The Professional Papers associated with each RASA study have a unique number with a series of chapters designated by letters, the letter A is reserved for the chapter that summarizes the major findings of the particular aquifer system. All Professional Papers derived from the RASA Program are identified by a Professional Paper number between 1400 and 1427.

Book reports published by the U.S. Geological Survey can be purchased from:

U.S. Geological Survey

Books and Open-File Reports Section

Box 25425, Federal Center

Denver, CO 80225

Phone: (303) 236-7476

Hydrologic Investigations Atlases and maps can be purchased from:

U.S. Geological Survey
Map Distribution
Federal Center
Box 25286
Denver, CO 80225
Phone: (303) 236-7477

Scientific journal articles and symposium proceedings must be obtained from the journals or sponsoring organizations.

As of May 1991, the RASA Program has produced 876 reports. Three of these reports, listed below, explain and summarize the RASA Program. The other 873 reports are listed at the end of each section that briefly describes the study that produced the reports. The RASA Program has also produced many abstracts for presentations made at scientific meetings; these abstracts are not listed in this report.

1. Bennett, G.D., 1979, Regional ground-water systems analysis: U.S. Army Corps of Engineers Water Spectrum, v. 11, no. 4, p. 36-42.

2. Sun, R.J., ed., 1986, Regional Aquifer-System Analysis Program of the U.S. Geological Survey--summary of projects, 1978-84: U.S. Geological Survey Circular 1002, 264 p. (out of print). 
3. Weeks, J.B., and Sun, R.J., 1987, Regional Aquifer-System Analysis Program of the U.S. Geological Survey--bibliography, 1978-86: U.S. Geological Survey Water-Resources Investigations Report 87-4138, 81 p.

\section{ACKNOWLEDGMENTS}

The authors wish to thank the Regional Aquifer-System Analysis (RASA) Project Chiefs and their staffs, and the District Chiefs and their staffs who worked on the RASA studies and who reviewed the accuracy of this bibliography. Their assistance made possible that this compilation of the RASA reports was completed within a short period of time. 


\section{FULLY COMPLETED REGIONAL AQUIFER-SYSTEM ANALYSIS STUDIES}

\section{Floridan Aquifer System}

The Floridan aquifer system is one of the major sources of ground water in the United States. This highly productive aquifer system underlies all of Florida, southern Georgia, and small parts of adjacent Alabama and South Carolina; a total area of about 100,000 square miles.

The Floridan aquifer system includes several Tertiary carbonate formations that are hydraulically connected in various degrees to form a regional aquifer system. Locally there are significant differences in hydrologic properties, water chemistry, and flow. The aquifer system is a sequence of hydraulically connected carbonate rocks (principally limestone with some dolomite) that generally range in age from late Paleocene to early Miocene. The rocks range in thickness from a featheredge in outcrop areas to more than 3,500 feet in coastal areas. The aquifer system generally consists of an upper and lower aquifer separated by a less-permeable confining unit of highly variable properties. In parts of northern Florida and southwestern Georgia, there are only small permeability contrasts within the aquifer system. Thus, in these areas, the Floridan acts effectively as one continuous aquifer.

Development of the Floridan aquifer system has proceeded unevenly with large withdrawals concentrated in a few areas. A total of about 3 billion gallons per day is withdrawn from the aquifer system as of the early 1980's. In many areas, the aquifer system is the sole source of freshwater. A considerable area of the Floridan aquifer system remains highly favorable for development of large ground-water supplies. This favorable area is potential for largely inland from the coast and is characterized by high transmissivity as well as minimal development in 1985 . The major constraint on future development is potential for degradation of water quality. The possibility of saltwater encroachment in coastal areas and upconing of deep saltwater in some inland areas is an important factor to be considered for future development.

The objectives of the Floridan aquifer system study, which began in 1978, were to (1) describe the hydrogeologic framework and geochemistry of the Floridan aquifer system, (2) analyze the regional flow system, and (3) assess the effects of large withdrawals of ground water from the aquifer system. The study was conducted in two phases. During phase I (completed in 1984), the regional flow system was described and modeled using a regional flow model and four subregional flow models. The regional flow model was used to understand the major features of the flow system. The four subregional flow models were used to focus on the areas of greatest ground-water development. During phase II (completed in 1986), detailed investigations of local aspects of the aquifer system were conducted including a petrographic study of carbonate rocks comprising the Floridan aquifer system in central Florida and a study of saltwater movement at Hilton Head Island, South Carolina. The study has completed 45 reports as listed below.

1. Bush, P.W., 1982a, Predevelopment flow in the Tertiary limestone aquifer southeastern United States--a regional analysis from digital modeling: U.S. Geological Survey WaterResources Investigations Report 82-905, $41 \mathrm{p}$.

2. 1982b, Southeast Tertiary limestone aquifer flow system: American Society of Civil Engineers National Speciality Conference on Environmentally Sound Water and Soil Management, Proceedings, Orlando, Florida, p. 237-240. 
3. 1988, Simulation of saltwater movement in the Floridan aquifer system, Hilton Head Island, South Carolina: U.S. Geological Survey Water-Supply Paper 2331, 19 p.

4. Bush, P.W., Barr, G.L., Clarke, J.S., and Johnston, R.H., 1987, Potentiometric surface of the Upper Floridan aquifer in Florida and in parts of Georgia, South Carolina, and Alabama, May 1985: U.S. Geological Survey Water-Resources Investigations Report 86-4316, scale $1: 1,000,000$.

5. Bush, P.W., and Johnston, R.H., 1986, Floridan regional aquifer-system study, in Sun, R.J., ed., Regional Aquifer-System Analysis Program of the U.S. Geological Survey--summary of projects, 1978-84: U.S. Geological Survey Circular 1002, p. 17-29.

6. 1988, Ground-water hydraulics, regional flow, and ground-water development of the Floridan aquifer system in Florida and in parts of Georgia, South Carolina, and Alabama: U.S. Geological Survey Professional Paper 1403-C, 80 p.

7. Bush, P.W., Miller, J.A., and Maslia, M.L., 1986, Floridan regional aquifer system, phase II study, in Sun, R.J., ed., Regional Aquifer-System Analysis Program of the U.S. Geological Survey--summary of projects, 1978-84: U.S. Geological Survey Circular 1002, p. 249-254.

8. Chapelle, F.H., Morris, J.T., McMahon, P.B., and Zelibor, J.L., Jr., 1988, Bacterial metabolism and the del-13C composition of ground water in Floridan aquifer system, South Carolina: Geology, v. 16, p. 117-121.

9. Johnston, R.H., 1978, Planning report for the Southeastern Limestone regional aquifersystem analysis: U.S. Geological Survey Open-File Report 78-516, 26 p.

10. 1983, The saltwater-freshwater interface in the Tertiary limestone aquifer, southeast Atlantic outer-continental shelf of the USA: Journal of Hydrology, v. 61, p. 239-249.

11. 1989, The hydrologic responses to development in regional sedimentary aquifers: Ground Water, v. 27, no. 3, p. 316-322.

12. Johnston, R.H., and Bush, P.W., 1988, Summary of the hydrology of the Floridan aquifer system in Florida and in parts of Georgia, South Carolina, and Alabama: U.S. Geological Survey Professional Paper 1403-A, 24 p.

13. Johnston, R.H., Bush, P.W., Krause, R.E., Miller, J.A., and Sprinkle, C.L., 1982, Summary of hydrologic testing in Tertiary limestone aquifer, Tenneco offshore exploratory well-Atlantic OCS, lease-block 427 (Jacksonville NH 17-5): U.S. Geological Survey Water-Supply Paper 2180, $15 \mathrm{p}$.

14. Johnston, R.H., Bush, P.W., and Miller, J.A., 1987, Hydrology of the Floridan aquifer system, in Vecchioli, John, and Johnson, A.I., eds., Regional Aquifer Systems of the United States, Aquifers of the Atlantic and Gulf Coastal Plain: American Water Resources Association Monograph Series, no. 9, p. 153-166.

15. Johnston, R.H., Healy, H.G., and Hayes, L.R., 1981, Potentiometric surface of the Tertiary limestone aquifer system, southeastern United States, May 1980: U.S. Geological Survey OpenFile Report 81-486, scale 1:1,000,000.

16. Johnston, R.H., Krause, R.E., Meyer, F.W., Ryder, P.D., Tibbals, C.H., and Hunn, J.D., 1980, Estimated potentiometric surface for the Tertiary limestone aquifer system, southeastern 
United States, prior to development: U.S. Geological Survey Open-File Report 80-406, scale $1: 1,000,000$.

17. Johnston, R.H., and Miller, J.A., 1988, Region 24, Southeastern United States, in Back, William, Rosenshein, J.S., and Seaber, P.R., eds, Hydrogeology: Boulder, Colorado, Geological Society of America, Geology of North America, v. O-2, p. 229-236.

18. Krause, R.E., 1982, Digital model evaluation of the predevelopment flow system of the Tertiary limestone aquifer system, southeast Georgia, northeast Florida, and southern South Carolina: U.S. Geological Survey Water-Resources Investigations Report 82-173, 27 p.

19. Krause, R.E., and Randolph, R.B., 1989, Hydrology of the Floridan aquifer system in southeast Georgia and adjacent parts of Florida and South Carolina: U.S. Geological Survey Professional Paper 1403-D, 65 p.

20. Maslia, M.L., and Hayes, L.R., 1988, Hydrogeology and simulated effects of ground-water development of the Floridan aquifer system, southwest Georgia, northwest Florida, and southern most Alabama: U.S. Geological Survey Professional Paper 1403-H, 71 p.

21. Matthews, S.E., and Krause, R.E., 1984, Hydrogeologic data from the U.S. Geological Survey test wells near Waycross, Ware County, Georgia: U.S. Geological Survey WaterResources Investigations Report 83-4204, 29 p.

22. Meyer, F.W., 1984, Disposal of liquid wastes in cavernous dolostones beneath southeastern Florida, in Hydrogeology of Karstic Terrains: International Association of Hydrogeologists, v. 1, p. 211-216.

23. 1988, Summary of well construction, testing, and preliminary findings from the Alligator Alley test well, Broward County, Florida: U.S. Geological Survey Open-File Report $87-551,68 \mathrm{p}$.

24. 1989a, Hydrogeology, ground-water movement, and subsurface storage in the Floridan aquifer system in southern Florida: U.S. Geological Survey Professional Paper 1403-G, 59 p.

25. 1989b, Subsurface storage of liquids in the Floridan aquifer system in south Florida: U.S. Geological Survey Open-File Report 88-477, 25 p.

26. Miller, J.A., 1982a, Configuration of the base of the upper permeable zone of the Tertiary limestone aquifer system, southeastern United States: U.S. Geological Survey Water-Resources Investigations Report 81-1177, scale 1:1,000,000.

27. 1982b, Geology and configuration of the base of the Tertiary limestone aquifer system, southeastern United States: U.S. Geological Survey Open-File Report 81-1176, scale $1: 1,000,000$.

28. $1982 \mathrm{c}$, Geology and configuration of the top of the Tertiary limestone aquifer system, southeastern United States: U.S. Geological Survey Open-File Report 81-1178, scale $1: 1,000,000$.

29. 1982d, Thickness of the Tertiary limestone aquifer system, southeastern United States: U.S. Geological Survey Open-File Report 81-1124, scale 1:1,000,000. 
30. 1982e, Thickness of the upper permeable zone of the Tertiary limestone aquifer system, southeastern United States: U.S. Geological Survey Water-Resources Investigations Report 81-1179, scale 1:1,000,000.

31. 1986, Hydrogeologic framework of the Floridan aquifer system in Florida and in parts of Georgia, South Carolina, and Alabama: U.S. Geological Survey Professional Paper 1403-B, 91 p.

32. Navoy, A.S., 1986, Hydrogeologic data from a 2,000-foot deep core hole at Polk City, Green Swamp area, central Florida: U.S. Geological Survey Water-Resources Investigations Report 84-4257, 89 p.

33. Rutledge, A.T., 1989, A computer program for converting rectangular coordinates to latitude-longitude coordinates: U.S. Geological Survey Water-Resources Investigations Report $89-4070,16 \mathrm{p}$.

34. Ryder, P.D., 1982, Digital model of predevelopment flow in the Tertiary limestone (Floridan) aquifer system in west-central Florida: U.S. Geological Survey Water-Resources Investigations Report 81-54, $61 \mathrm{p}$.

35. 1985, Hydrology of the Floridan aquifer system in west-central Florida: U.S. Geological Survey Professional Paper 1403-F, 63 p.

36. Smith, C.A., Lidz, Lauralee, and Meyer, F.W., 1982, Data on selected deep wells in south Florida: U.S. Geological Survey Open-File Report 82-348, 144 p.

37. Sprinkle, C.L., 1982a, Chloride concentration in water from the upper permeable zone of the Tertiary limestone aquifer system, southeastern United States: U.S. Geological Survey WaterResources Investigations Report 81-1103, scale 1:1,000,000.

38. $1982 \mathrm{~b}$, Dissolved-solids concentration in water from the upper permeable zone of the Tertiary limestone aquifer system, southeastern United States: U.S. Geological Survey WaterResources Investigations Report 82-94, scale 1:1,000,000.

39. 1982c, Sulfate concentration in water from the upper permeable zone of the Tertiary limestone aquifer system, southeastern United States: U.S. Geological Survey Water-Resources Investigations Report 81-1101, scale 1:1,000,000.

40. 1982d, Total hardness of water from the upper permeable zone of the Tertiary limestone aquifer system, southeastern United States: U.S. Geological Survey Water-Resources Investigations Report 81-1102, scale 1:1,000,000.

41. 1989, Geochemistry of the Floridan aquifer system in Florida and in parts of Georgia, South Carolina, and Alabama: U.S. Geological Survey Professional Paper 1403-I, 105 p.

42. Thayer, P.A., and Miller, J.A., 1984, Petrology of lower and middle Eocene carbonate rocks, Floridan aquifer, central Florida: Gulf Coast Association of Geological Societies Transactions, v. XXXIV, p. 421-434.

43. Tibbals, C.H., 1981, Computer simulation of the steady-state flow system of the Tertiary limestone (Floridan) aquifer system in east-central Florida: U.S. Geological Survey WaterResources Investigations Report 81-681, 31 p. 
44. 1990, Hydrology of the Floridan aquifer system in east-central Florida: U.S. Geological Survey Professional Paper 1403-E, 98 p.

45. Tibbals, C.H., and Grubb, H.F., 1982, Aquifer test results, Green Swamp area, Florida: U.S. Geological Survey Water-Resources Investigations Report 82-35, 29 p.

\section{High Plains}

The area of the High Plains regional aquifer-system analysis study is 174,000 square miles of flat to gently rolling terrain in parts of Colorado, Kansas, Nebraska, New Mexico, Oklahoma, South Dakota, Texas, and Wyoming. Ground water from the High Plains aquifer is the primary source of water supply in this area with few perennial streams. More than 90 percent of water used in the High Plains is obtained from the High Plains aquifer. About 95 percent of water used for irrigation is from the aquifer. Because of a plentiful supply of suitable-quality ground water, irrigation has transformed the High Plains into one of the Nation's major agricultural areas.

The High Plains aquifer consists mainly of near-surface sand and gravel deposits. The Tertiary Ogallala Formation, which underlies about 80 percent of the High Plains, is the principal geologic unit of the aquifer. The saturated thickness of the High Plains aquifer averages about 200 feet, and the maximum thickness is about 1,000 feet in central Nebraska. Ground water generally flows from west to east and discharges naturally to streams and springs and by evapotranspiration in areas where the water table is near land surface. Infiltration of precipitation and seepage from streams are the principal sources of recharge to the aquifer.

Because the High Plains are located in a semi-arid region, recharge to the aquifer is small. This small recharge coupled with large pumpage in parts of Texas, New Mexico, and Kansas have caused severe depletion of water in aquifer storage and declining water levels in these areas.

National concern about the economic effect of declining water supplies in the High Plains led to the beginning of a regional study of the High Plains aquifer in 1978. The objectives of the study were to provide (1) hydrologic data needed to evaluate the effects of continued ground-water development, and (2) computer models for evaluating aquifer response to pumping of ground water. The study was conducted in two phases. During phase I (completed in 1982), the geohydrologic framework of the aquifer system was evaluated, and computer models of groundwater flow were developed. During phase II (completed in 1986), irrigation return flow was evaluated, 1980-to-2020 pumpage was estimated using irrigated acreage and water use projection made by the U.S. Department of Commerce, and aquifer response to future pumpage was evaluated using computer models. The study has completed 122 reports as listed below.

1. Alley, W.M., and Emery, P.A., 1986, Groundwater model of the Blue River Basin, Nebraska--twenty years later: Journal of Hydrology, v. 85, p. 225-249.

2. Alley, W.M., and Schefter, J.E., 1987, External effects of irrigators' pumping decisions, High Plains aquifer: Water Resources Research, v. 23, no. 7, p. 1123-1130.

3. Ashworth, J.B., 1980, Results of test hole drilling: Texas Department of Water Resources Report LP-129, 41 p.

4. 1984, Hydraulic characteristics of the High Plains aquifer as determined from core analysis, in Whetstone, G.A., ed., Proceedings of the Ogallala Aquifer Symposium II: Texas Tech University, Lubbock, Texas, June 1984, p. 278-291. 
5. Avery, Charles, 1983, Pumpage data from irrigation wells in eastern Laramie County, Wyoming, and Kimball County, Nebraska: U.S. Geological Survey Open-File Report $83-29,23$ p.

6. Avery, Charles, and Pettijohn, R.A., 1984, Generalized potentiometric-surface map of the High Plains aquifer system in Wyoming, 1981: U.S. Geological Survey Water-Resources Investigations Report 84-4033, scale 1:250,000.

7. Borman, R.G., 1983, Predevelopment and 1980 water table in the northern High Plains of Colorado; and water-level changes, predevelopment to 1980, and 1975 to 1980: U.S. Geological Survey Hydrologic Investigations Atlas HA-670, scale 1:500,000 and 1:1,000,000.

8. Borman, R.G., and Gaggiani, N.G., 1983, Generalized altitude and configuration of the water table in parts of Larimer, Logan, Sedgwick, and Weld Counties, Colorado: U.S. Geological Survey Water-Resources Investigations Report 82-4055, scale 1:250,000.

9. Borman, R.G., Lindner, J.B., Bryn, S.M., and Rutledge, John, 1983, The Ogallala aquifer in the northern High Plains of Colorado--saturated thickness in 1980; saturated-thickness changes, predevelopment to 1980; hydraulic conductivity; specific yield; and predevelopment and 1980 probable well yields: U.S. Geological Survey Hydrologic Investigations Atlas HA-671, scale $1: 500,000$ and $1: 1,000,000$.

10. Borman, R.G., and Meredith, T.S., 1983, Geology, altitude, and depth of the bedrock surface beneath the Ogallala Formation in the northern High Plains of Colorado: U.S. Geological Survey Hydrologic Investigations Atlas HA-669, scale 1:500,000.

11. Borman, R.G., Meredith, T.S., and Bryn, S.M., 1984, Geology, altitude, and depth of the bedrock surface; altitude of the water table in 1980; and saturated thickness of the Ogallala aquifer in 1980 in the southern High Plains of Colorado: U.S. Geological Survey Hydrologic Investigations Atlas HA-673, scale 1:500,000.

12. Borman, R.G., and Reed, R.L., 1984, Location of irrigation wells and application rates for irrigated cropland during 1980 in the northern High Plains of Colorado: U.S. Geological Survey Hydrologic Investigations Atlas HA-675, scale 1:500,000.

13. Cobb, P.M., Colarullo, S.J., and Manoutchehr, Heidari, 1983, A ground-water flow model for the Great Bend aquifer, south-central Kansas: Kansas State Geological Survey Open-File Report 83-20, 220 p.

14. Cooley, M.E., 1984a, Linear features determined from Landsat imagery in the Texas and Oklahoma Panhandles: U.S. Geological Survey Open-File Report 84-589, scale 1:500,000.

15. 1984b, Linear features determined from Landsat imagery in western Kansas: U.S. Geological Survey Open-File Report 84-241, scale 1:500,000.

16. 1986, Divisions of potential fracture permeability, based on distribution of structures and lineaments, in sedimentary rocks of the Rocky Mountains-High Plains region, western United States: U.S. Geological Survey Water-Resources Investigations Report 85-4091, scale $1: 2,500,000$.

17. DeAngelis, Robert, 1980, Irrigated cropland, 1978, Hockley and Lamb Counties, Texas: U.S. Geological Survey Open-File Report 80-168, scale 1:250,000. 
18. Dugan, J.T., 1984, Hydrologic characteristics of Nebraska soils: U.S. Geological Survey Water-Supply Paper 2222, 19 p.

19. Dugan, J.T., Hobbs, R.D., and Ihm, L.A., 1990, Hydrologic characteristics of soils in the High Plains, Northern Great Plains, and Texas carbonates regional aquifer systems: U.S. Geological Survey Hydrologic Atlas HA-714, scale 1:3,168,000.

20. Feder, G.L., and Krothe, N.C., 1981, Results of a reconnaissance water-quality sampling program of the Ogallala aquifer in Colorado, Kansas, Nebraska, Oklahoma, South Dakota, and Texas: U.S. Geological Survey Water-Resources Investigations Report 81-65, 7 p.

21. Ferrigno, C.F., 1986a, Machine-readable files developed for the High Plains regional aquifer-system analysis in parts of Colorado, Kansas, Nebraska, New Mexico, Oklahoma, South Dakota, Texas, and Wyoming: U.S. Geological Survey Water-Resources Investigations Report 86-4063, 23 p.

22. 1986b, A data-management system for detailed areal interpretive data: U.S. Geological Survey Water-Resources Investigation Report 86-4091, 103 p.

23. Gutentag, E.D., Heimes, F.J., Krothe, N.C., Luckey, R.R., and Weeks, J.B., 1984, Geohydrology of the High Plains aquifer in parts of Colorado, Kansas, Nebraska, New Mexico, Oklahoma, South Dakota, Texas, and Wyoming: U.S. Geological Survey Professional Paper 1400-B, 63 p.

24. Gutentag, E.D., and Weeks, J.B., 1980, Water table in the High Plains aquifer in 1978 in parts of Colorado, Kansas, Nebraska, New Mexico, Oklahoma, South Dakota, Texas, and Wyoming: U.S. Geological Survey Hydrologic Investigations Atlas HA-642, scale 1:2,500,000.

25. Hart, D.L., Jr., and McAda, D.P., 1985, Geohydrology of the southern High Plains of New Mexico: U.S. Geological Survey Hydrologic Investigations Atlas HA-679, scale 1:500,000.

26. Havens, J.S., 1982a, Generalized altitude and configuration of the base of the High Plains regional aquifer, northwestern Oklahoma: U.S. Geological Survey Water-Resources Investigations Report 81-1117, scale 1:250,000, 2 sheets.

27. 1982b, Altitude and configuration of the 1980 water table in the High Plains regional aquifer, northwestern Oklahoma: U.S. Geological Survey Water-Resources Investigations Report $82-100$, scale $1: 250,000,2$ sheets.

28. 1982c, Altitude and configuration of the predevelopment water table in the High Plains regional aquifer, northwestern Oklahoma: U.S. Geological Survey Water-Resources Investigations Report 82-275, scale 1:250,000, 2 sheets.

29. 1982d, Saturated thickness of the High Plains regional aquifer in 1980, northwestern Oklahoma: U.S. Geological Survey Water-Resources Investigations Report 82-760, scale $1: 250,000,2$ sheets.

30. 1983, Predevelopment to 1980 water-level changes in the High Plains regional aquifer, northwestern Oklahoma: U.S. Geological Survey Water-Resources Investigations Report $83-4073$, scale $1: 500,000$.

31. 1985, Water-level changes in the Ogallala aquifer, northwestern Oklahoma: Oklahoma State Geological Survey, Geology Notes, v. 45, no. 5, p. 205-210. 
32. Havens, J.S., and Christenson, S.C., 1984, Numerical simulation of the High Plains regional aquifer, northwestern Oklahoma: U.S. Geological Survey Water-Resources Investigations Report $83-4269,27 \mathrm{p}$.

33. Heimes, F.J., 1984, The High Plains regional aquifer--estimating 1980 ground-water pumpage for irrigation, in Whetstone, G.A., ed., Proceedings of the Ogallala Aquifer Symposium II: Texas Tech University, Lubbock, Texas, June 1984, p. 26-39.

34. 1989, The High Plains regional aquifer-estimating 1980 ground-water pumpage for irrigation, in Swain, L.A. and Johnson. A.I., eds, Regional Aquifer Systems of the United States, Aquifers of the Midwestern Area: American Water Resources Association Monograph Series, no. 13 , p. $207-218$.

35. Heimes, F.J., Ferrigno, D.F., Gutentag, E.D., Luckey, R.R., Stephens, D.M., and Weeks, J.B., 1987, Comparison of irrigation pumpage with change in ground-water storage in the High Plains aquifer in Chase, Dundy, and Perkins Counties, Nebraska, 1975-83: U.S. Geological Survey Water-Resources Investigations Report 87-4404, 34 p.

36. Heimes, F.J., and Luckey, R.R., 1980, Evaluating methods for determining water use in the High Plains in parts of Colorado, Kansas, Nebraska, New Mexico, Oklahoma, South Dakota, Texas, and Wyoming, 1979: U.S. Geological Survey Water-Resources Investigations Report 80-111, 118 p.

37. 1982 , Method for estimating historical irrigation requirements from ground water in the High Plains aquifer in parts of Colorado, Kansas, Nebraska, New Mexico, Oklahoma, South Dakota, Texas, and Wyoming: U.S. Geological Survey Water-Resources Investigations Report $82-40,64 \mathrm{p}$.

38. 1983, Estimating 1980 ground-water pumpage for irrigation on the High Plains in parts of Colorado, Kansas, Nebraska, New Mexico, Oklahoma, South Dakota, Texas, and Wyoming: U.S. Geological Survey Water-Resources Investigations Report 83-4123, 36 p.

39. Heimes, F.J., Luckey, R.R., and Stephens, D.M., 1986, Evaluation of sampling methods used to estimate irrigation pumpage in Chase, Dundy, and Perkins Counties, Nebraska: U.S. Geological Survey Water-Resources Investigations Report 86-4092, 27 p.

40. Johnson, Robert, 1980a, Irrigated cropland, 1978, Chase, Dundy, and Perkins Counties, Nebraska: U.S. Geological Survey Open-File Report 80-641, scale 1:250,000.

41. 1980b, Irrigated cropland, 1978, Cheyenne and Sherman Counties, Kansas: U.S. Geological Survey Open-File Report 80-640, scale 1:250,000.

42. Johnson, Thomas, 1980a, Irrigated cropland, 1978, Kit, Carson, Phillips, and Yuma Counties, Colorado: U.S. Geological Survey Open-File Report 80-639, scale 1:250,000.

43. 1980b, Irrigated cropland, 1978, Laramie County, Wyoming: U.S. Geological Survey Open-File Report 80-638, scale 1:250,000.

44. Jonas, Peter, and Wright, Bruce, 1979a, Irrigated cropland, 1978, Cherry County, Nebraska: U.S. Geological Survey Open-File Report 79-1629, scale 1:250,000.

45. 1979b, Irrigated cropland, 1978, Todd County, South Dakota: U.S. Geological Survey Open-File Report 79-1627, scale 1:250,000. 
46. Klemt, W.B., 1981, Neutron-probe measurements of deep soil moisture as an indication of aquifer recharge rates: Texas Department of Water Resources Report LP-142, 31 p.

47. Knowles, Tommy, 1981, GWSIM-III, ground-water simulation program documentation and user's manual: Texas Department of Water Resources Report UM-36, 84 p.

48. 1984, Assessment of the ground-water resources of the Texas High Plains, in Whetstone, G.A., ed., Proceedings of the Ogallala Aquifer Symposium II: Texas Tech University, Lubbock, Texas, June 1984, p. 217-237.

49. Knowles, Tommy, Nordstrom, Phillip, and Klemt, W.B., 1981a, Evaluating the groundwater resources of the High Plains of Texas, basic data for middle third of region: Texas Department of Water Resources Final Report LP-173, v. 3, 477 p.

50 . 1981b, Evaluating the ground-water resources of the High Plains of Texas, basic data for southern third of region: Texas Department of Water Resources Final Report LP-173, v. 4,389 p.

51. 1982a, Evaluating the ground-water resources of the High Plains of Texas, basic data for northern third of region: Texas Department of Water Resources Final Report LP-173, v. $2,451 \mathrm{p}$.

52. $1982 \mathrm{~b}$, Evaluating the ground-water resources of the High Plains of Texas: Texas Department of Water Resources Final Report LP-173, v. 1, 174 p.

53. Kolm, K.E., and Case, H.L., III, 1983, A two-dimensional, finite-difference model of the High Plains aquifer in South Dakota: U.S. Geological Survey Water-Resources Investigations Report 83-4175, 34 p.

54. 1984, Evaluation of techniques for identifying irrigated crop types and estimating acreages from Landsat imagery in the High Plains of South Dakota: Journal of Photogrammetric Engineering and Remote Sensing, v. 50, no. 10, p. 1479-1490.

55. Krothe, N.C., and Oliver, J.W., 1982, Sulphur isotopic composition and water chemistry in water from the High Plains aquifer, Oklahoma Panhandle and southwestern Kansas: U.S. Geological Survey Water-Resources Investigations Report 82-12, 28 p.

56. Krothe, N.C., Oliver, J.W., and Weeks, J.B., 1982, Dissolved solids and sodium in water from the High Plains aquifer in parts of Colorado, Kansas, Nebraska, New Mexico, Oklahoma, South Dakota, Texas, and Wyoming: U.S. Geological Survey Hydrologic Investigations Atlas HA-658, scale 1:2,500,000, 2 sheets.

57. Lindner-Lunsford, J.B., and Borman, R.G., 1985, Potential well yields from the Ogallala aquifer in the northern High Plains of Colorado: U.S. Geological Survey Hydrologic Investigations Atlas HA-685, scale 1:1,000,000.

58. Loskot, C.L., Case, H.L., III, and Hern, D.G., 1984, Geologic and hydraulic data from a test-drilling program in the High Plains area of South Dakota, 1979-80: U.S. Geological Survey Open-File Report 84-148, 31 p.

59. Luckey, R.R., 1984a, Projected effects of ground-water development in the southern High Plains of Texas and New Mexico: American Water Works Association, Dallas, Texas, June 10-14, 1984, Proceedings, p. 1345-1362. 
60. 1984b, The High Plains regional aquifer--flow system simulation of the central and northern High Plains, in Whetstone, G.A., ed., Proceedings of the Ogallala Aquifer Symposium II: Texas Tech University, Lubbock, Texas, June 1984, p. 48-66.

61. Luckey, R.R., and Ferrigno, C.F., 1982, A data-management system for areal interpretive data for the High Plains in parts of Colorado, Kansas, Nebraska, New Mexico, Oklahoma, South Dakota, Texas, and Wyoming: U.S. Geological Survey Water-Resources Investigations Report $82-4072,112 \mathrm{p}$.

62. Luckey, R.R., Gutentag, E.D., Heimes, F.J., and Weeks, J.B., 1986, Digital simulation of ground-water flow in the High Plains aquifer in parts of Colorado, Kansas, Nebraska, New Mexico, Oklahoma, South Dakota, Texas, and Wyoming: U.S. Geological Survey Professional Paper 1400-D, 57 p.

63. 1988, Effects of future ground-water pumpage on the High Plains aquifer in parts of Colorado, Kansas, Nebraska, New Mexico, Oklahoma, South Dakota, Texas, and Wyoming: U.S. Geological Survey Professional Paper 1400-E, 44 p.

64. Luckey, R.R., Gutentag, E.D., and Weeks, J.B., 1981, Water-level and saturated-thickness changes, predevelopment to 1980 , in the High Plains aquifer in parts of Colorado, Kansas, Nebraska, New Mexico, Oklahoma, South Dakota, Texas, and Wyoming: U.S. Geological Survey Hydrologic Investigations Atlas HA-652, scale 1:2,500,000, 2 sheets.

65. Luckey, R.R., Heimes, F.J., and Gaggiani, N.G., 1980, Calibration and testing of selected portable flow meters for use on large irrigation systems: U.S. Geological Survey WaterResources Investigations Report 80-72, 21 p.

66. Luckey, R. R., and Stephens, D. M., 1987, Effect of grid size on digital simulation of ground-water flow in the southern High Plains of Texas and New Mexico: U.S. Geological Survey Water-Resources Investigations Report 87-4085, 32 p.

67. Mackey, G.W., 1987, Comparison of irrigation pumpage and changes in water storage in the High Plins aquifer in Castro and Parmer Counties, Texas 1975-83: U.S. Geological Survey Water-Resources Investigations Report 87-4032, 48 p.

68. Martinko, E.A., Poracsky, J., Kipp, E.R., Krieger, H., and Gunn, K., 1981, Crop phenology and Landsat-based irrigated lands inventory in the High Plains: Lawrence, Kansas, University of Kansas, Applied Remote Sensing Program Final Report NAG 2-57, 129 p.

69. McAda, D.P., 1984, Projected water-level declines in the Ogallala aquifer in Lea County, New Mexico: U.S. Geological Survey Water-Resources Investigations Report 84-4062, 84 p.

70. Muller, D.A., 1980, Results of surface electrical resistivity surveys: Texas Department of Water Resources Report LP-130, 27 p.

71. Nordstrom, P.L., 1984, Estimation of specific yield using drillers' lithologic descriptions, in Whetstone, G.A., ed., Proceedings of the Ogallala Aquifer Symposium II: Texas Tech University, Lubbock, Texas, June 1984, p. 265-277.

72. Pabst, M.E., and Stullken, L.E.,1982a, Altitude and configuration of the water table in the High Plains aquifer of Kansas, 1960: U.S. Geological Survey Open-File Report 82-429, scale 1:500,000. 
73. $1982 \mathrm{~b}$, Altitude and configuration of the water table in the High Plains aquifer of Kansas, 1965: U.S. Geological Survey Open-File Report 82-449, scale 1:500,000.

74. 1982c, Altitude and configuration of the water table in the High Plains aquifer of Kansas, 1970: U.S. Geological Survey Open-File Report 82-448, scale 1:500,000.

75. 1984, Altitude and configuration of the water table in the High Plains aquifer of Kansas, 1980: U.S. Geological Survey Open-File Report 81-1004, scale 1:500,000.

76. Pettijohn, R.A., and Chen, H.H., 1983a, Geohydrology of the High Plains aquifer system in Nebraska: U.S. Geological Survey Water-Resources Investigations Report 82-502, scale $1: 175,000,3$ sheets.

77. 1983b, Hydraulic conductivity, specific yield, and pumpage--High Plains aquifer system, Nebraska: U.S. Geological Survey Water-Resources Investigations Report 82-4014, scale $1: 175,000,3$ sheets.

78. 1984a, Hydrologic analysis of the High Plains aquifer system in Box Butte County, Nebraska: U.S. Geological Survey Water-Resources Investigations Report 84-4046, 54 p.

79. 1984b, Hydrologic characteristics and ground-water availability in the High Plains aquifer system in Nebraska, in Whetstone, G.A., ed., Proceedings of the Ogallala Aquifer Symposium II: Texas Tech University, Lubbock, Texas, June 1984, p. 238-264.

80. Rettman, P.L., and McAdoo, G.D., 1986, Irrigation data from Castro and Parmer Counties, Texas, 1983-84: U.S. Geological Survey Open-File Report 85-699, 36 p.

81. Stephens, D.M., Heimes, F.J., and Luckey, R.R., 1984, Irrigation data from Chase, Dundy, and Perkins Counties, southwestern Nebraska, 1983: U.S. Geological Survey Open-File Report 84-471, $31 \mathrm{p}$.

82. 1985, Irrigation data from Chase, Dundy, and Perkins Counties, southwestern Nebraska, 1984: U.S. Geological Survey Open-File Report 85-164, 32 p.

83. Stullken, L.E., and Pabst, M.E., 1981, Altitude and configuration of the water table in the High Plains aquifer of Kansas, 1975: U.S. Geological Survey Water-Resources Investigations Report 81-144, scale 1:500,000.

84. 1985, Altitude and configuration of the water table in the High Plains aquifer of Kansas, pre-1950: U.S. Geological Survey Open-File Report 82-117, scale 1:500,000.

85. Stullken, L.E., Watts, K.R., and Lindgren, R.J., 1985, Geohydrology of the High Plains aquifer, western Kansas: U.S. Geological Survey Water-Resources Investigations Report $85-4198,86 \mathrm{p}$.

86. Thelin, G.P., 1984, The High Plains aquifer--mapping irrigated agriculture using Landsat data, in Whetstone, G.A., ed., Proceedings of the Ogallala Aquifer Symposium II: Texas Tech University, Lubbock, Texas, June 1984, p. 40-47.

87. 1988, The High Plains regional aquifer--mapping irrigated agriculture using Landsat data, in Swain, L.A. and Johnson, A.I., eds, Regional Aquifer Systems of the United States, Aquifers of the Midwestern Area: American Water Resources Association Monograph Series no. 13 , p. 219-223. 
88. Thelin, G.P., and Heimes, F.J., 1987, Mapping irrigated cropland from Landsat data for determination of water-use from the High Plains aquifer in parts of Colorado, Kansas, Nebraska, New Mexico, Oklahoma, South Dakota, Texas, and Wyoming: U.S. Geological Survey Professional Paper 1400-C, 39 p.

89. Thelin, G.P., Johnson, T.L, and Johnson, R.A., 1979, Mapping irrigated cropland on the High Plains using Landsat, in Deutsch, M., Wiesnet, D.R., and Rango, A., eds., Satellite Hydrology: American Water Resources Association Pecora Symposium, 5th, Sioux Falls, South Dakota, 1979, Proceedings, p. 715-721.

90. Watts, K.R., and Stullken, L.E., 1985, Generalized configuration of the base of the High Plains regional aquifer in Kansas: U.S. Geological Survey Open-File Report 81-344, scale 1:500,000.

91. Weeks, J.B., 1978a, High Plains regional aquifer-system analysis, in Baird, F.L., ed., The Multi-Faceted Water Crisis of West Texas: Symposium, Texas Tech University, Lubbock, Texas, November 8-9, 1978, Proceedings, p. 195-201.

92. 1978b, High Plains regional aquifer-system analysis: Groundwater Management Districts Association Conference, 5th: Amarillo, Texas, 1978, Proceedings, p. 13-16.

93. 1978c, Plan of study for the High Plains regional aquifer-system analysis in parts of Colorado, Kansas, Nebraska, New Mexico, Oklahoma, South Dakota, Texas, and Wyoming: U.S. Geological Survey Water-Resources Investigations Report 78-70, 28 p.

94. 1979, High Plains regional aquifer-system analysis--progress report: Groundwater Management Districts Association Conference, 6th, Colorado Springs, Colorado, 1979, Proceedings, p. 10-13.

95. 1981, Effects of pumpage on the High Plains aquifer: Groundwater Management Districts Association Conference, 8th, Lubbock, Texas, 1981, Proceedings, p. 97-108.

96. 1985, A bibliography of the High Plains regional aquifer-system analysis: Groundwater Management Districts Association Conference, 12th, Reno, Nevada, 1985, Proceedings, p. 4-18.

97. 1986a, High Plains regional aquifer-system study, in Sun, R.J., ed., Regional Aquifer-System Analysis Program of the U.S. Geological Survey--summary of projects, 1978-84: U.S. Geological Survey Circular 1002, p. 30-49.

98. 1986b, High Plains regional aquifer system, phase II study, in Sun, R.J., ed., The Regional Aquifer-System Analysis Program of the U.S. Geological Survey--summary of projects, 1978-84: U.S. Geological Survey Circular 1002, p. 255-258.

99. Weeks, J.B., and Gutentag, E.D., 1981, Bedrock geology, altitude of base, and 1980 saturated thickness of the High Plains aquifer in parts of Colorado, Kansas, Nebraska, New Mexico, Oklahoma, South Dakota, Texas, and Wyoming: U.S. Geological Survey Hydrologic Investigations Atlas HA-648, scale 1:2,500,000, 2 sheets.

100. 1984, The High Plains regional aquifer--geohydrology, in Whetstone, G.A., ed., Proceedings of the Ogallala Aquifer Symposium II: Texas Tech University, Lubbock, Texas, June 1984, p. 6-25. 
101. 1988a, Region 17, High Plains, in Back, William, Rosenshein, J.S., and Seaber, P.R., eds., Hydrogeology: Boulder, Colorado, Geological Society of America, Geology of North America, v. O-2, p. 157-164.

102. 1988b, The High Plains regional aquifer--geohydrology, in Swain, L.A., and Johnson, A.I., eds, Regional Aquifer Systems of the United States, Aquifers of the Midwestern Area: American Water Resources Associations Monograph Series, no. 13, p. 191-206.

103. Weeks, J.B., Gutentag, E.D., Heimes, F.J., and Luckey, R.R., 1988, Summary of the High Plains regional aquifer-system analysis in parts of Colorado, Kansas, Nebraska, New Mexico, Oklahoma, South Dakota, Texas, and Wyoming: U.S. Geological Survey Professional Paper 1400-A, 30 p.

104. Weeks, J.B., and Luckey, R.R., 1987, Simulated effects of future pumpage on the High Plains aquifer, west-central United States: International Groundwater Conference, University of Kebangsaan Malaysia, Kuala Lumpur, Malaysia, June 22-26, 1987, Proceedings, p. G79-G87.

105. 1988, Simulated effects of future pumpage on the High Plains aquifer, west-central United States, in Swain, L.A., and Johnson, A.I., eds; Regional Aquifer Systems of the United States, Aquifers of the Midwestern Area: American Water Resources Association Monograph Series, no. 13, p. 225 - 235.

106. Wright, Bruce, 1980a, Irrigated cropland, 1978, Curry County, New Mexico: U.S. Geological Survey Open-File Report 80-169, scale 1:250,000.

107. 1980b, Irrigated cropland, 1978, Texas County, Oklahoma: U.S. Geological Survey Open-File Report 80-170, scale 1:250,000.

108. Wyatt, A.W., Smith, D.D., and McReynolds, Don, 1981a, Hydrologic atlas for Armstrong County, Texas: High Plains Underground Water Conservation District No.1, Lubbock, Texas, scale $1: 126,720,4$ sheets.

109. 1981b, Hydrologic atlas for Bailey County, Texas: High Plains Underground Water Conservation District No.1, Lubbock, Texas, scale 1:126,720, 4 sheets.

110. 1981c, Hydrologic atlas for Castro County, Texas: High Plains Underground Water Conservation District No.1, Lubbock, Texas, scale 1:126,720, 4 sheets.

111. 1981d, Hydrologic atlas for Cochran County, Texas: High Plains Underground Water Conservation District No.1, Lubbock, Texas, scale 1:126,720, 4 sheets.

112. 1981e, Hydrologic atlas for Crosby County, Texas: High Plains Underground Water Conservation District No.1, Lubbock, Texas, scale 1:126,720, 4 sheets.

113. 1981f, Hydrologic atlas for Deaf Smith County, Texas: High Plains Underground Water Conservation District No.1, Lubbock, Texas, scale 1:126,720, 4 sheets.

114. 1981g, Hydrologic atlas for Floyd County, Texas: High Plains Underground Water Conservation District No.1, Lubbock, Texas, scale 1:126,720, 4 sheets.

115. 1981h, Hydrologic atlas for Hale County, Texas: High Plains Underground Water Conservation District No.1, Lubbock, Texas, scale 1:126,720, 4 sheets. 
116. 1981i, Hydrologic atlas for Hockley County, Texas: High Plains Underground Water Conservation District No.1, Lubbock, Texas, scale 1:126,720, 4 sheets.

117. 1981j, Hydrologic atlas for Lamb County, Texas: High Plains Underground Water Conservation District No.1, Lubbock, Texas, scale 1:126,720, 4 sheets.

118. 1981k, Hydrologic atlas for Lubbock County, Texas: High Plains Underground Water Conservation District No.1, Lubbock, Texas, scale 1:126,720, 4 sheets.

119. 19811, Hydrologic atlas for Lynn County, Texas: High Plains Underground Water Conservation District No.1, Lubbock, Texas, scale 1:126,720, 4 sheets.

120. 1981m, Hydrologic atlas for Parmer County, Texas: High Plains Underground Water Conservation District No.1, Lubbock, Texas, scale 1:126,720, 4 sheets.

121. 1981n, Hydrologic atlas for Potter County, Texas: High Plains Underground Water Conservation District No.1, Lubbock, Texas, scale 1:126,720, 4 sheets.

122. 1981o, Hydrologic atlas for Randall County, Texas: High Plains Underground Water Conservation District No.1, Lubbock, Texas, scale 1:126,720, 4 sheets.

\section{Northern Atlantic Coastal Plain}

The Northern Atlantic Coastal Plain is a gently rolling to flat region of about 50,000 square miles that extends along the coast from Long Island, New York, to the North Carolina-South Carolina State boundary. It is underlain by a seaward thickening wedge of predominantly unconsolidated sediments that thickens from a featheredge at the Fall Line in the west to more than 8,000 feet along the Coast of Maryland and 10,000 feet at Cape Hatteras, North Carolina. The sediments consist mostly of gravel, sand, silt, and clay of Jurassic to Holocene age. Limestone occurs principally in North Carolina.

This sedimentary wedge forms a complex aquifer system in which the sand, gravel, and limestone function as aquifers, and the clay and silt function as confining units. The sediments can be divided into a number of aquifers and confining units based on the predominant lithologies, depositional environment, and hydraulic relations between the sediments. Lateral facies shifts that were caused by marine transgressions and regressions determine the areal distribution of the aquifers and confining units.

Ground-water recharge to the Northern Atlantic Coastal Plain aquifer system is derived from precipitation and occurs chiefly in upland and interfluvial areas. The recharge rate ranges from 10 to 25 inches per year, and most of the recharge flows through shallow unconfined parts of the system and discharges to local streams that dissect the Coastal Plain. A small amount of the recharge water, generally less than 1 inch per year, replenishes the deeper confined part of the aquifers. Under natural conditions, discharge from the confined aquifers is primarily upward across the confining units into shallower aquifers and ultimately into major rivers, the sea, or coastal estuaries, sounds, and bays. Saltwater underlies freshwater in the seaward part of the Coastal Plain. Areas of shallow saltwater generally coincide with areas of natural ground-water discharge.

Withdrawal of water from the confined part of this aquifer system, principally for municipal and industrial use, has grown from about 100 million gallons per day in 1900 to about 1,200 million gallons per day in 1980. Pumping from the confined aquifer system has caused 
widespread potentiometric head declines that have significantly altered ground-water recharge, discharge, and flow patterns.

The Northern Atlantic Coastal Plain regional aquifer-system analysis study was started in 1979 and completed in 1987, and resulted in a computer model to simulate the ground-water flow throughout the region. The model includes ten aquifers and nine confining units. Four subregional models were also developed to provide better spatial resolutions. These subregional models were used to aid in understanding of the aquifer system, its response to pumping, and the relations between freshwater and saltwater within the aquifer system. As of May 1991, the study has completed 35 reports as listed below. One report, describing regional ground-water quality and its chemical evolution in the entire Northern Atlantic Coastal Plain aquifer system by Knobel, L.L., and Chapelle, F.H., is in review.

1. Chapelle, F.H., and Knobel, L.L., 1983, Aqueous geochemistry and the exchangeable cation composition of glauconite in the Aquia aquifer, Maryland: Ground Water, v. 21, no. 3, p. 343-352.

2. 1985, Stable carbon isotopes of bicarbonate in the Aquia aquifer, Maryland--evidence for an isotopically heavy source of carbon dioxide: Ground Water, v. 23, no. 5, p. 592-599.

3. Chapelle, F.H., and Loveley, D.R., 1990, Rates of microbial metabolism in deep coastal plain aquifers: Applied and Environmental Microbiology, v. 56, no. 6, p. 1865-1874.

4. Chapelle, F.H., Zelibor, J.L., Jr., Grimes, D.J., and Knobel, L.L., 1987, Bacteria in deep coastal plain sediments of Maryland--a possible source of $\mathrm{CO}_{2}$ to ground water: Water Resources Research, v. 23, no. 8.

5. Fleck, W.B., and Vroblesky, D.A., in press, Simulation of ground-water flow of the coastal plain aquifers in parts of Maryland, Delaware, and District of Columbia: U.S. Geological Survey Professional Paper 1404-J.

6. Coble, R.W., Giese, G.L., and Winner, M.D., Jr., 1987, Application of regional aquifersystem analysis study results to ground-water management in North Carolina, in Vecchioli, John, and Johnson, A.I., eds., Regional Aquifer Systems of the United States, Aquifers of the Atlantic and Gulf Coastal Plain: American Water Resources Association Monograph Series, no. 9 , p. 39-49.

7. Garber, Murray, 1986, Geohydrology of the Lloyd aquifer, Long Island, New York: U.S. Geological Survey Water-Resources Investigations Report 85-4159, 36 p.

8. Giese, B.L., Eimers, J.L., and Coble, R.W., 1991, Simulation of ground-water flow in the coastal plain aquifer system of North Carolina: U.S. Geological Survey Open-File Report 90-372, 178 p., pending publication as Professional Paper 1404-M.

9. Harsh, J.F., and Laczniak, R.J., 1990, Conceptualization and analysis of the ground-water flow system in the coastal plain aquifers of Virginia and adjacent parts of Maryland and North Carolina: U.S. Geological Survey Professional Paper 1404-F, 100 p.

10. Knobel, L.L., 1985, Ground-water-quality data for the Atlantic Coastal Plain, New Jersey, Delaware, Maryland, Virginia, and North Carolina: U.S. Geological Survey Open-File Report $85-154,84 \mathrm{p}$. 
11. Knobel, L.L., Chapelle, F.H., and Phillips, S.W., 1987, Overview of geochemical processes controlling the chemistry of ground water in the Aquia and Magothy aquifers, Northern Atlantic Coastal Plain, Maryland, in Vecchioli, John, and Johnson, A.I., eds., Regional Aquifer Systems of the United States, Aquifers of the Atlantic and Gulf Coastal Plain: American Water Resources Association Monograph Series, no. 9, p. 25-37.

12. Knobel, L.L., Leahy, P.P., 1981, DUROV, a FORTRAN program for plotting chemical parameters on a hydrochemical facies diagram: U.S. Geological Survey Water Resources Bulletin, October-December 1981, p. 34-41.

13. Knobel, L.L., and Phillips, Scott, 1988, Aqueous geochemistry of the Magothy aquifer, Maryland: U.S. Geological Survey Water-Supply Paper 2323, 28 p.

14. Kull, T.K., and Laczniak. R.J., 1987, Ground-water withdrawals from the confined aquifers of the Coastal Plain of Virginia, 1891-1983: U.S. Geological Survey Water Resources Investigations Report 87-4049, $37 \mathrm{p}$.

15. Leahy, P.P., 1982, A three-dimensional ground-water flow model modified to reduce computer-memory requirements and better simulate confining-bed and aquifer pinchouts: U.S. Geological Survey Water-Resources Investigations Report 82-4023, 60 p.

16. Leahy, P.P., and Martin, Mary, in press, Geohydrology and simulation of ground-water flow in the Northern Atlantic Coastal Plain aquifer system: U.S. Geological Survey Professional Paper 1404-K.

17. Leahy, P.P., Martin, Mary, and Meisler, Harold, 1987, Hydrologic definition of the Northern Atlantic Coastal Plain aquifer system based on regional simulation in Vecchioli, John, and Johnson, A.I., eds., Regional Aquifer Systems of the United States, Aquifers of the Atlantic and Gulf Coastal Plain: American Water Resources Association Monograph Series, no. 9, p. 7-24.

18. Martin, Mary, 1987, Methodology and use of interfacing regional and subregional groundwater flow models: National Water Well Association Solving Ground Water Problems with Models, Conference and Exposition, February 10-12, 1987, Denver, Colorado, Proceedings, v. 2, p. $1022-1036$.

19. 1990, Ground-water flow in the New Jersey Coastal Plain: U.S. Geological Survey Open-File Report 87-528, 182 p., pending publications as Professional paper 1404-H.

20. Meisler, Harold, 1980a, Plan of study for the Northern Atlantic Coastal Plain regional aquifersystem analysis: U.S. Geological Survey Water-Resources Investigations Report 80-16, 27 p.

21. 1980b, Preliminary delineation of salty ground water in the Northern Atlantic Coastal Plain: U.S. Geological Survey Open-File Report 81-71, 37 p.

22. 1989, The occurrence and geochemistry of salty ground water in the Northern Atlantic Coastal Plain: U.S. Geological Survey Professional Paper 1404-D, 51 p.

23. Meisler, Harold, Trapp, Henry, Jr., Leahy, P.P., Martin, Mary, Knobel, L.L., and Chapelle, F.H., 1986, Northern Atlantic Coastal Plain regional aquifer-system study, in Sun, R.J., ed., Regional Aquifer-System Analysis Program of the U.S. Geological Survey--summary of projects, 1978-84: U.S. Geological Survey Circular 1002, p. 168-194. 
24. Meisler, Harold, Leahy, P.P., and Knobel, L.L., 1984, Effect of eustatic sea-level changes on saltwater-freshwater relations in the Northern Atlantic Coastal Plain: U.S. Geological Survey Water-Supply Paper 2255, 28 p.

25. Meisler, Harold, Miller, J.A., Knobel, L.L., and Wait, R.L., 1988, Region 22, Atlantic and Eastern Gulf Coastal Plain, in Back, William, Rosenshein, J.S., and Seaber, P.R., eds., Hydrogeology: Boulder, Colorado, Geological Society of America, Geology of North America, v. O-2, p. 209-218.

26. Meng, A.A., III, and Harsh, J.F., 1988, Hydrogeologic framework of the Virginia Coastal Plain: U.S. Geological Survey Professional Paper 1404-C, 82 p.

27. Trapp, Henry, Jr., Knobel, L.L., Meisler, Harold, and Leahy, P.P., 1984, Test well DO-CE 88 at Cambridge, Dorchester County, Maryland: U.S. Geological Survey Water-Supply Paper 2229, 48 p.

28. Trapp, Henry, Jr., in press, Hydrogeological framework of the Northern Atlantic Coastal Plain, in parts of North Carolina, Virginia, Maryland, Delaware, New Jersey, and New York: U.S. Geological Survey Professional Paper 1404-G.

29. Trapp, Henry, Jr., and Meisler, Harold, in press, The regional aquifer system underlying the Northern Atlantic Coastal Plain, in parts of North Carolina, Virginia, Maryland, Delaware, New Jersey, and New York: U.S. Geological Survey Professional Paper 1404-A.

30. Vroblesky, D.A., and Fleck, W.B., in press, Hydrogeologic framework of the Coastal Plain of Maryland, Delaware, and District of Columbia: U.S. Geological Survey Professional Paper 1404-E.

31. Wheeler, J.C., and Wilde, F.D., 1989, Ground-water use in the Coastal Plain of Maryland, 1900-80: U.S. Geological Survey Open-File Report 87-540, 173 p.

32. Winner, M.D., Jr., and Coble, R.W., 1989, Hydrogeologic framework of the North Carolina Coastal Plain aquifer system: U.S. Geological Survey Open-file Report 87-690, 155 p., pending publication as Professional Paper 1404-I.

33. Zapecza, O.S., 1989, Hydrogeologic framework of the New Jersey Coastal Plain: U.S. Geological Survey Professional Paper 1404-B, 49 p.

34. , in press, Hydrogeologic units in the Coastal Plain of New Jersey and their delineation by borehole geophysical methods, in Gohn, G.S., ed., Proceedings of the 1988 U.S. Geological Survey Workshop on the Geology and Geohydrology of the Atlantic Coastal Plain: U.S. Geological Survey Circular 1059.

35. Zapecza, O.S., Voronin, Lois, and Martin, Mary, 1987, Ground-water withdrawals and water-level data used to simulate regional flow in the major coastal plain aquifers in New Jersey: U.S. Water Resources Investigations Report 87-4038, 120 p.

\section{Northern Great Plains}

The area of the Northern Great Plains regional aquifer-system study is about 300,000 square miles and includes North Dakota and parts of South Dakota, Montana, Wyoming, and Nebraska. The Northern Great Plains mostly is underlain by sandstone, limestone, shale, and 
some evaporite deposits. Ground water generally flows northeastward across the area. The source of recharge is precipitation in topographically high areas. Ground water generally travels hundreds of miles and discharges into topographically low areas of eastern North Dakota and South Dakota and occurs as subsurface outflow into Canada. Some ground-water discharge also occurs as diffuse upward leakage into overlying shallower aquifers.

Flow characteristics vary significantly between the predominantly carbonate aquifers in Paleozoic rocks (such as the Madison Limestone) and the predominantly clastic aquifers in Mesozoic rocks (such as the Dakota Sandstone). Potential for flow between aquifers exists near recharge and discharge areas and in the interior part of the study area, where hydraulic heads differ significantly between aquifers.

Development of ground-water supplies in the Northern Great Plains will be needed for the growth of energy resources, power generation, industrial expansion, increasing irrigation, and domestic and municipal water use. Historically, streamflow has satisfied most of the water needs; however, surface water is fully appropriated in much of the area, and it is not always a dependable source because streamflows are extremely variable within a year and from year to year. Longterm, large-scale water needs require the development of ground-water resources.

A study of the Madison aquifer was initiated in 1975 to address the problems of water supplies associated with development of coal resources and the proposed coal-slurry pipelines in the Fort Union coal region. The Northern Great Plains regional aquifer-system study was started in 1978 to extend the study of the Madison aquifer and was completed in 1982. As of May 1991, the study has completed 75 reports as listed below, of which 9 reports were completed by the study of the Madison aquifer.

1. Anna, L.O., 1986, Geologic framework of the ground-water system in Jurassic and Cretaceous rocks in the Northern Great Plains in parts of Montana, North Dakota, South Dakota, and Wyoming: U.S. Geological Survey Professional Paper 1402-B, 36 p.

2. Blankennagel, R.K., Miller, W.R., Brown, D.L., and Cushing, E.M., 1977, Report on preliminary data for Madison Limestone test well no. 1, NE1/4SE1/4 sec. 15, T.57 N., R.65 W., Crook County, Wyoming: U.S. Geological Survey Open-File Report 77-164, 110 p.

3. Brown, D.L., Blankennagel, R.K., MacCary, L.M., and Peterson, J.A., 1984, Correlation of Paleostructure and sediment deposition in the Madison Limestone and associated rocks in parts of Montana, Nort Dakota, South Dakota, Wyoming, and Nebraska: U.S. Geological Survey Professional paper 1273-B, $24 \mathrm{p}$.

4. Busby, J.F., Kimball, B.A., Downey, J.S., and Peter, K.D., in press, Geochemistry of ground water in aquifers and confining units of the Northern Great Plains in parts of Montana, North Dakota, South Dakota, and Wyoming: U.S. Geological Survey Professional Paper 1402-F.

5. Busby, J.F., Plummer, L.N., Lee, R.W., and Hanshaw, B.B., 1991, Geochemical evolution of water in the Madison aquifer in parts of Montana, South Dakota, and Wyoming: U.S. Geological Survey Professional Paper 1273-F, 89 p.

6. Butler, R.D., 1984, Hydrogeology of the Dakota aquifer system, Williston Basin, North Dakota, in Jorgensen, D.G., and Signor, D.C., eds., Geohydrology of the Dakota Aquifer: National Water Well Association C.V. Theis Conferences on Geohydrology, 1st, Lincoln, Nebraska, October 5-6, 1982, Proceedings, p. 99-108. 
7. Case, H.L., III, 1984, Hydrology of Inyan Kara and Dakota-Newcastle aquifer system, South Dakota, in Jorgensen, D.G., and Signor, D.C., eds., Geohydrology of the Dakota Aquifer: National Water Well Association C.V. Theis Conferences on Geohydrology, 1st, Lincoln, Nebraska, October 5-6, 1982, Proceedings, p. 147-165.

8. Cooley, M.E., 1983a, Linear features determined from Landsat imagery in Montana: U.S. Geological Survey Open-File Report 83-936, scale 1:500,000, 2 sheets.

9. 1983b, Linear features determined from Landsat imagery in North Dakota: U.S. Geological Survey Open-File Report 83-937, scale 1:500,000.

10. 1983c, Linear features determined from Landsat imagery in South Dakota and parts of adjacent States: U.S. Geological Survey Open-File Report 83-548, scale 1:500,000.

11. 1983d, Linear features determined from Landsat imagery in Wyoming: U.S. Geological Survey Open-File Report 83-935, scale 1:500,000, 2 sheets.

12. 1986, Divisions of potential fracture permeability based on distribution of structures and linear features in sedimentary rocks, Northern Great Plains--Rocky Mountains region of Montana, North Dakota, South Dakota, Wyoming, and northern Nebraska: U.S. Geological Survey Miscellaneous Investigations Map I-1687, scale 1:1,335,000.

13. Dinwiddie, G.A., and Downey, J.S., 1986, Northern Great Plains regional aquifer-system study, in Sun, R.J., ed., Regional Aquifer-System Analysis Program of the U.S. Geological Survey--summary of projects, 1978-84: U.S. Geological Survey Circular 1002, p. 50-71.

14. Dodge, K.A., and Levings, G.W., 1980, Measurements of discharge, gain or loss in flow, and chemical quality of the Poplar and Redwater Rivers, northeastern Montana, October 24-25, 1979: U.S. Geological Survey Open-File Report 80-1210, 16 p.

15. Downey, J.S., 1982a, Geohydrology of the Madison and associated aquifers in parts of Montana, North Dakota, South Dakota, and Wyoming: U.S. Geological Survey Open-File Report 82-914, 130 p.

16. 1982b, Machine-readable data files from the Madison Limestone and Northern Great Plains regional aquifer-system analysis project, Montana, Nebraska, North Dakota, South Dakota, and Wyoming: U.S. Geological Survey Water-Resources Investigations Report 82-4107, 26 p.

17. 1983, Bedrock aquifers of the Northern Great Plains: American Society of Civil Engineers Specialty Conference, Jackson, Wyoming, July 1983, Proceedings, p. 29-35.

18. 1984a, Geohydrology of the Madison and associated aquifers in parts of Montana, North Dakota, South Dakota, and Wyoming: U.S. Geological Survey Professional Paper 1273-G, $47 \mathrm{p}$.

19. 1984b, Hydrodynamics of the Williston Basin in the Northern Great Plains, in Jorgensen, D.G., and Signor, D.C., eds., Geohydrology of the Dakota Aquifer: National Water Well Association C.V. Theis Conferences on Geohydrology, 1st, Lincoln, Nebraska, October 5-6, 1982, Proceedings, p. 92-98.

20. 1986, Geohydrology of bedrock aquifers in the Northern Great Plains in parts of Montana, North Dakota, South Dakota, and Wyoming: U.S. Geological Survey Professional Paper 1402-E, 87 p. 
21. 1988, Regional bedrock aquifers of the Northern Great Plains, north-central United

States, in McLean, J.S., and Johnson, A.I., eds, Regional Aquifer Systems of the United States, Aquifers of the Western Mountain Area: American Water Resources Association Monograph Series, no. 14 , p. 5-13.

22. Downey, J.S., and Dinwiddie, G.A., 1988, The regional aquifer system underlying the Northern Great Plains in parts of Montana, North Dakota, South Dakota, and Wyoming-summary: U.S. Geological Survey Professional Paper 1402-A, 64 p.

23. Downey, J.S., and Weiss, E.J., 1980, Preliminary data set for three-dimensional digital model of the Red River and Madison aquifers: U.S. Geological Survey Open-File Report 80-746, $8 \mathrm{p}$.

24. Druse, S.A., Dodge, K.A., and Hotchkiss, W.R., 1981, Base flow and chemical quality of streams in the Northern Great Plains area, Montana and Wyoming, 1977-78: U.S. Geological Survey Water-Resources Investigations Report 81-692, 60 p.

25. Feltis, R.D., 1982a, Map showing altitude of the top of the Judith River Formation, Montana: U.S. Geological Survey Water-Resources Investigations Report 82-4027, scale 1:1,000,000.

26. 1982b, Map showing total thickness of the Judith River Formation, Montana: U.S. Geological Survey Water-Resources Investigations Report 82-4028, scale 1:1,000,000.

27. 1982c, Map showing cumulative thickness of sandstone in the Judith River Formation, Montana: U.S. Geological Survey Water-Resources Investigations Report 82-4038, scale $1: 1,000,000$.

28. 1982d, Map showing altitude of the top of the Swift Formation, Montana: U.S. Geological Survey Water-Resources Investigations Report 82-4029, scale 1:1,000,000.

29. 1982e, Map showing total thickness of the Swift Formation, Montana: U.S. Geological Survey Water-Resources Investigations Report 82-4031, scale 1:1,000,000.

30. ___ 1982f, Map showing cumulative thickness of sandstone in the Swift Formation, Montana: U.S. Geological Survey Water-Resources Investigations Report 82-4030, scale $1: 1,000,000$.

31. 1982g, Map showing altitude of the top of the Eagle Sandstone, Montana: U.S. Geological Survey Water-Resources Investigations Report 82-4034, scale 1:1,000,000.

32. 1982h, Map showing total thickness of the Eagle Sandstone and Telegraph Creek Formation, Montana: U.S. Geological Survey Water-Resources Investigations Report 82-4033, scale $1: 1,000,000$.

33. 1982i, Map showing cumulative thickness of sandstone in the Eagle Sandstone and Telegraph Creek Formation, Montana: U.S. Geological Survey Water-Resources Investigations Report 82-4032, scale 1:1,000,000.

34. 1982j, Map showing altitude of the top of the "Dakota Sandstone," Montana: U.S. Geological Survey Water-Resources Investigations Report 82-4036, scale 1:1,000,000.

35. 1982k, Map showing total thickness of the "Dakota Sandstone," Montana: U.S. Geological Survey Water-Resources Investigations Report 82-4037, scale 1:1,000,000. 
36. 19821, Map showing cumulative thickness of sandstone in the "Dakota Sandstone," Montana: U.S. Geological Survey Water-Resources Investigations Report 82-4035, scale $1: 1,000,000$.

37. 1982m, Map showing altitude of the top of the Lakota Formation and equivalent rocks, Montana: U.S. Geological Survey Water-Resources Investigations Report 82-4039, scale $1: 1,000,000$.

38. 1982n, Map showing total thickness of the Lakota Formation and equivalent rocks, Montana: U.S. Geological Survey Water-Resources Investigations Report 82-4026, scale $1: 1,000,000$.

39. 1982o, Map showing cumulative thickness of sandstone in the Lakota Formation and equivalent rocks, Montana: U.S. Geological Survey Water-Resources Investigations Report 82-4040, scale 1:1,000,000.

40. 1982p, Map showing altitude of the top of the Fox Hills-Lower Hell Creek aquifer, Montana: U.S. Geological Survey Water-Resources Investigations Report 82-4041, scale $1: 1,000,000$.

41. 1982q, Map showing total thickness of the Fox Hills-Lower Hell Creek aquifer, Montana: U.S. Geological Survey Water-Resources Investigations Report 82-4042, scale $1: 1,000,000$.

42. 1982r, Map showing cumulative thickness of sandstone in the Fox Hills-Lower Hell Creek aquifer, Montana: U.S. Geological Survey Water-Resources Investigations Report $82-4043$, scale $1: 1,000,000$.

43. Feltis, R.D., Lewis, B.D., Frasure, R.L., Rioux, R.P., Jauhola, C.A., and Hotchkiss, W.R., 1981, Selected geologic data from the Northern Great Plains area of Montana: U.S. Geological Survey Water-Resources Investigations Report 81-415, 66 p.

44. Henderson, Thomas, 1985 , Geochemistry of ground water in two sandstone aquifer systems in the Northern Great Plains in parts of Montana, North Dakota, South Dakota, and Wyoming: U.S. Geological Survey Professional Paper 1402-C, 84 p.

45. Hotchkiss, W.R., 1982, The ground water resource in Montana: Montana Environmental Quality Council Ground Water Conference [Planning a Ground-water Strategy], Helena, Montana, 1982, Summary Proceedings, p. 5-8.

46. Kolm, K.E., and Peter, K.D., 1984, A possible relation between lineaments and leakage through confining layers in South Dakota in Jorgensen, D.G., and Signor, D.C., eds., Geohydrology of the Dakota Aquifer: National Water Well Association C.V. Theis Conferences on Geohydrology, 1st, Lincoln, Nebraska, October 5-6, 1982, Proceedings, p. 121-134.

47. Larson, L.R., and Daddow, R.L., 1984, Ground-water quality data from the Powder River structural basin and adjacent areas, northeastern Wyoming: U.S. Geological Survey Open-File Report 83-939, 56 p.

48. Lenfest, L.W., Jr., 1987, Evapotranspiration rates at selected sites in the Powder River basin, Wyoming and Montana: U.S. Geological Survey Water-Resources Investigations Report $82-4105,23 \mathrm{p}$. 
49. Levings, G.W., 1981a, Selected drill-stem-test data from the Northern Great Plains area of Montana: U.S. Geological Survey Water-Resources Investigations Report 81-326, 20 p.

50. U.S. Geological Survey Open-File Report 81-534, 241 p.

51. 1982a, Potentiometric-surface map of water in the Eagle Sandstone and equivalent units in the Northern Great Plains of Montana: U.S. Geological Survey Open-File Report 82-565, scale $1: 1,000,000$.

52. 1982b, Potentiometric-surface map of water in the Fox Hills-Lower Hills Creek aquifer in the Northern Great Plains of Montana: U.S. Geological Survey Open-File Report 82-564, scale $1: 1,000,000$.

53. 1982c, Potentiometric-surface map of water in the Judith River Formation in the Northern Great Plains area of Montana: U.S. Geological Survey Open-File Report 82-562, scale $1: 1,000,000$.

54. 1982d, Potentiometric-surface map of water in the Lakota Formation and equivalent units in the Northern Great Plains of Montana: U.S. Geological Survey Open-File Report 82-563, scale $1: 1,000,000$.

55. Levings, J.F., 1983, Hydrogeology and simulation of water flow in the Kootenai aquifer of the Judith basin, central Montana: U.S. Geological Survey Water-Resources Investigations Report 83-4146, $39 \mathrm{p}$.

56. Levings, J.F., and Dodge, K.A., 1981, Selected hydrogeologic data from the Judith basin, central Montana: U.S. Geological Survey Open-File Report 81-1015, 98 p.

57. Levings, J.F., Levings, G.W., Feltis, R.D., Hotchkiss, W.R., and Lee, R.E., 1981, Selective annotated bibliography of geology and ground-water resources for the Montana part of the Northern Great Plains regional aquifer-system analysis: U.S. Geological Survey WaterResources Investigations Report 81-401, 91 p.

58. Lewis, B.D., and Hotchkiss, W.R., 1981, Thickness, percent sand, and configuration of shallow hydrogeologic units in the Powder River basin, Montana and Wyoming: U.S. Geological Survey Miscellaneous Investigations Map I-1317, scale 1:1,000,000, 6 sheets.

59. Lobmeyer, D.H., 1980, Preliminary potentiometric-surface map showing freshwater heads for the Lower Cretaceous rocks in the Northern Great Plains of Montana, North Dakota, South Dakota, and Wyoming: U.S. Geological Survey Open-File Report 80-757, scale 1:1,000,000.

60 . 1985, Freshwater heads and ground-water temperatures in aquifers of the Northern Great Plains in parts of Montana, North Dakota, South Dakota, and Wyoming: U.S. Geological Survey Professional Paper 1402-D, 11 p.

61. Lobmeyer, D.H., Anna, L.O., and Busby, J.F., 1982, Preliminary data for Northern Great Plains test well 1, NW1/4NE1/4 sec. 11, T.55N., R.77W., Sheridan County, Wyoming: U.S. Geological Survey Open-File Report 82-446, 72 p.

62. MacCary, L.M, 1984, Apparent water resistivity, porosity, and water temperature of the Madison Limestone and underlying rocks in parts of Montana, Nebraska, North Dakota, South Dakota, and Wyoming: U.S. Geological Survey Professional Paper 1273-D, 14 p. 
63. MacCary, L.M., Cushing, E.M., and Brown, D.L., 1983, Potentially favorable areas for large-yield wells in the Red River Formation and Madison Limestone in parts of Montana, North Dakota, South Dakota, and Wyoming: U.S. Geological Survey Professional Paper 1273-E, 13 p.

64. Peter, K.D., 1984, Hydrochemistry of Lower Cretaceous sandstone aquifers, Northern Great Plains, in Jorgenson, D.G., and Signor, D.C., eds. Geohydrology of the Dakota Aquifer: National Water Well Association C.V. Theis Conferences on Geohydrology, 1st, Lincoln, Nebraska, October 5-6, 1982, Proceedings, p. 197-208.

65. Peter, K.D., Kolm, K.E., Downey, J.S., and Nichols, T.C., 1988, Lineaments:

Significance criteria for determination and varied effects on ground-water system--a case history in the use of remote sensing: American Society of Testing Material Specific Technical Publication 1967, p. 46-68.

66. Peterson, J.A., 1978, Subsurface geology and porosity distribution, Madison Limestone and underlying formations, Powder River Basin, northeastern Wyoming and southeastern Montana, and adjacent areas: U.S. Geological Survey Open-File Report 78-783, 9 p.

67. 1984, Stratigraphy and sedimentary facies of the Madison Limestone and associated rocks in parts of Montana, Nebraska, North Dakota, South Dakota, and Wyoming: U.S. Geological Survey Professional Paper 1273-A, 34 p.

68. Plummer, L.N., Busby, J.F., Lee, R.W., and Hanshaw, B.B., 1990, Geochemical modeling of the Madison aquifer in parts of Montana, Wyoming, and South Dakota: Water Resources Research, v. 26, no. 9, p. 1981-2014.

69. Rioux, R.P., and Dodge, K.A., 1980, Hydrologic data from the Bull Mountains area, southcentral Montana: U.S. Bureau of Land Management Report, 146 p.

70. Stenzil, Sheila, Buss, Rebecca, and Busby, J.F., 1980, Maps showing dissolved-solids concentration of waters in the Red River Formation and Mission Canyon Limestone in North Dakota, South Dakota, and parts of Wyoming and Montana: U.S. Geological Survey Open-File Report 80-748, scale 1:1,000,000, 2 sheets.

71. Thayer, P.A., 1983, Relationship of porosity and permeability to petrology of the Madison Limestone in rock cores from three test wells in Montana and Wyoming: U.S. Geological Survey Professional Paper 1273-C, 29 p.

72. U.S. Geological Survey, 1979, Plan of study for the Northern Great Plains regional aquifersystem analysis in parts of Montana, North Dakota, South Dakota, and Wyoming: U.S. Geological Survey Water-Resources Investigations Report 79-34, 20 p.

73. Weimer, R.J., Emme, J.J., Farmer, C.L., Anna, L.O., Davis, T.L., and Kidney, R.L., 1982, Tectonic influences of sedimentation, early Cretaceous, east flank of the Powder River basin, Wyoming and South Dakota: Colorado School of Mines Quarterly, v. 77, no. 4, 61 p.

74. Weiss, Emanuel, 1982a, A computer program for calculating relative transmissivity input arrays to aid model calibration: U.S. Geological Survey Open-File Report 82-447, 18 p.

75. $1982 \mathrm{~b}$, A model for the simulation of flow of variable density ground water in three dimensions under steady-state conditions: U.S. Geological Survey Open-File Report $82-352,66$ p. 


\section{Northern Midwest}

The objectives of the Northern Midwest regional aquifer-system analysis study were to investigate the hydrogeology, ground-water availability, and chemical quality of water in an aquifer system consisting of rocks of Cambrian and Ordovician age in parts of Illinois, Indiana, Iowa, Minnesota, Missouri, and Wisconsin. Thereafter, this regional aquifer system is termed the Cambrian-Ordovician aquifer system. The study area is about 161,000 square miles.

The Cambrian-Ordovician aquifer system contains three major aquifers--the St. PeterPrairie du Chien-Jordan aquifer, the Ironton-Galesville aquifer, and the Mount Simon aquifer. The aquifers consist primarily of sandstone separated by low permeability shale, shaly dolomite, or siltstone. Where the Maquoketa Shale is present, the shale and the underlying dolomite and shale strata of the Galena Dolomite and Decorah, Platteville, and Glenwood Formations form a major regional confining unit that overlies the three aquifers.

The Cambrian-Ordovician aquifer system is a leaky-artesian system. Movement of ground water is partly controlled by low permeability confining units of shale, shaly dolomite, or siltstone. In the upland and outcrop areas where the system is thin, water-table conditions exist. Much of the recharge occurs in those areas. Most of the recharge water flows locally, less than a few miles, and discharges into nearby streams. The remainder of the recharge moves slowly downward to deeper formations which are part of the regional confined ground-water flow system.

The Cambrian-Ordovician aquifer system supplies a major part of the water needs in the study area. The aquifer system is used extensively for industrial, municipal, and rural water supplies in the six States. Many metropolitan areas depend on the aquifer system for all or part of their water supplies. Hydraulic heads in the aquifer system in the heavily pumped ChicagoMilwaukee area have declined hundreds of feet since the late 1800's and to a lesser extent in other major metropolitan areas. Projections of future water needs indicate continuing or increasing demands and, therefore, continuing water-level declines in the heavily pumped areas are expected.

The study was started in 1978 and completed in 1984. As of May 1991, the study has completed 31 reports as listed below. One report describing the simulation results of the groundwater conditions in the Chicago-Milwaukee area due to development is in review.

1. Balding, G.O., in press, Changes in chloride concentration in water from municipal wells that tap aquifers in rocks of Cambrian and Ordovician age in northeastern Illinois, 1915-84: U.S. Geological Survey Water-Resources Investigations Report 90-4116.

2. Barnes, M.J., 1985, The extent and behavior of the mineralized water in the Mt. Simon Formation, northeastern Illinois: DeKalb, Illinois, Northern Illinois University, Master of Science Thesis, $127 \mathrm{p}$.

3. Bennett, G.D., Kontis, A.L., and Larson, S.P., 1982, Representation of multiaquifer well effects in three-dimensional ground-water flow simulation: Ground Water, v. 20, no. 3, p. 334-341.

4. Burkart, M.R., and Buchmiller, R.C., 1990, Regional evaluation of hydrologic factors and effects of pumping, St. Peter-Jordan aquifer, Iowa: U.S. Geological Survey Water-Resources Investigations Report 90-4009, 44 p. 
5. Delin, G.N., and Woodward, D.G., 1984, Hydrogeologic setting and potentiometric surfaces of regional aquifers in the Hollandale Embayment, southeastern Minnesota, 1970-80: U.S. Geological Survey Water-Supply Paper 2219, 56 p.

6. Emmons, P.J., 1987, An evaluation of the bedrock aquifer system in northeastern Wisconsin: U.S. Geological Survey Water-Resources Investigations Report 85-4199, 48 p.

7. Fassnacht, T.L., 1982, A seismic reflection study of the Precambrian basement along the Illinois-Wisconsin State line: DeKalb, Illinois, Northern Illinois University, Master of Science Thesis, $103 \mathrm{p}$.

8. Franz, K.E., 1985, Geochemistry of the sandstone and Silurian aquifers in eastern Wisconsin: Syracuse, New York, Syracuse University, Master of Science Thesis, 103 p.

9. Horn, M.A., 1983, Ground-water-use trends in the Twin Cities metropolitan area, Minnesota, 1880-1980: U.S. Geological Survey Water-Resources Investigations Report 83-4033, 37 p.

10. Imes, J.L., 1985, The ground-water flow system in northern Missouri, with emphasis on the Cambrian-Ordovician aquifer: U.S. Geological Survey Professional Paper 1305, 61 p.

11. Kontis, A.L., and Mandle, R.J., 1980, Data-base system for Northern Midwest regional aquifer-system analysis: U.S. Geological Survey Water-Resources Investigations Report $80-104,23$ p.

12. 1988, Modifications of a three-dimensional ground-water flow model to account for variable water density and effects of multiaquifer wells: U.S. Geological Survey Water Resources Investigations Report 87-4265, 78 p.

13. Mandle, R.J., and Kontis, A.L., in press, Simulation of regional ground-water flow in the Cambrian-Ordovician aquifer system in the Northern Midwest, United States: U.S. Geological Survey Professional Paper 1405-C.

14. Mossler, J.H., 1983a, Bedrock topography and isopachs of Cretaceous and Quaternary strata, east-central and southeastern Minnesota: Minnesota State Geological Survey Miscellaneous Map Series M-52, scale 1:500,000, 2 sheets.

15. 1983b, Paleozoic lithostratigraphy of southeastern Minnesota: Minnesota State Geological Survey Miscellaneous Map Series M-51, scale 1:500,000, 8 sheets.

16. Nicholas, J.R., Sherrill, M.G., and Young, H.L., 1987, Hydrogeology of the CambrianOrdovician aquifer system at a test well in northeastern Illinois: U.S. Geological Survey WaterResources Investigations Report 84-4165, 30 p.

17. Siegel, D.I., 1989, Geochemistry of the Cambrian-Ordovician aquifer system in the Northern Midwest: U.S. Geological Survey Professional Paper 1405-D, 76 p.

18. 1990, Sulfur isotope evidence for regional recharge of saline water during continental glaciation, north-central United States: Geology, v. 18, p. 1054-1056.

19. 1991, Evidence for dilution of deep, confined ground water by vertical recharge of isotopically heavy Pleistocene water: Geology, v. 19, p. 433-436. 
20. Siegel, D.I., and Begor, K.F., 1989, The geochemistry of the sandstone aquifer, southern Wisconsin, in Swain, L.A. and Johnson, A.I., eds; Regional Aquifer Systems of the United States, Aquifers of the Midwestern area: American Water Resources Association Monograph series, no. 13, p. $73-82$.

21. Siegel, D.I., and Mandle R.J., 1984, Isotopic evidence for glacial meltwater recharge to the Cambrian-Ordovician aquifer, north-central United States: Journal of Quaternary Research, v. 22 , p. $328-335$.

22. Steinhilber, W.L., and Young, H.L., 1979, Plan of study for the Northern Midwest regional aquifer-system analysis: U.S. Geological Survey Water-Resources Investigations Report 79-44, 20 p.

23. Visocky, A.P., Sherrill, M.G., and Cartwright, Keros, 1985, Geology, hydrology, and water quality of the Cambrian and Ordovician systems in northern Illinois: Illinois State Geological Survey and Illinois State Water Survey Cooperative Groundwater Report 10, $136 \mathrm{p}$.

24. Woodward, D.G., 1984, Areal lithologic changes in aquifers in southeastern Minnesota as determined from natural-gamma borehole logs: National Water Well Association Conference on Surface and Borehole Geophysical Methods in Ground Water Investigations, San Antonio, Texas, February 7-9, 1984, Proceedings, p. 788-800.

25. 1985, Trends in municipal-well installations and aquifer utilization in southeastern Minnesota, 1880-1980: U.S. Geological Survey Water-Resources Investigations Report $83-4222,99 \mathrm{p}$.

26. 1986, Hydrogeologic framework and properties of regional aquifers in the Hollandale embayment, southeastern Minnesota: U.S. Geological Survey Hydrologic Investigations Atlas HA-677, scale 1:1,000,000, 2 sheets.

27. Young, H.L., in press, Summary of ground-water hydrology of the Cambrian-Ordovician aquifer system in the Northern Midwest: U.S. Geological Survey Professional Paper 1405-A.

28. in press, Hydrogeology of the Cambrian-Ordovician aquifer system in the Northern Midwest: U.S. Geological Survey Professional Paper 1405-B.

29. Young, H.L., Mackenzie, A.J., and Mandle, R.J., 1989, Simulation of ground-water flow in the Cambrian-Ordovician aquifer system in the Chicago-Milwaukee area of the Northern Midwest, in Swain, L.A. and Johnson, A.I., eds; Regional Aquifer Systems of the United States, Aquifers of the Midwestern Area: American Water Resources Association Monograph Series, no. 13 , p. $39-72$.

30. Young, H.L., Mandle, R.J., Kontis, A.L., and Siegel, D.I., 1989, The Cambrian-Ordovician regional aquifer system in the Northern Midwest - a summary, in Swain, L.A., and Johnson, A.I., eds., Regional Aquifer Systems of the United States, Aquifers of the Midwestern Area: American Water Resources Association Monograph Series, no. 13, p. 5-37.

31. Young, H.L., Siegel, D.I., Mandle, R.J., and Kontis, A.L., 1986, Northern Midwest regional aquifer-system study, in Sun, R.J., ed., Regional Aquifer-System Analysis Program of the U.S. Geological Survey--summary of projects, 1978-84: U.S. Geological Survey Circular 1002, p. 72-87. 


\section{Southeastern Coastal Plain}

The Southeastern Coastal Plain aquifer system underlies an area of about 130,000 square miles in parts of South Carolina, Georgia, Alabama, Mississippi, and adjacent areas of northern Florida and southwestern North Carolina. The Southeastern Coastal Plain aquifer system is located among the three adjacent studied regional aquifer systems: the Northern Atlantic Coastal Plain to the northeast, the Floridan to the south and southeast, and the Gulf Coastal Plain to the west.

The Southeastern Coastal Plain aquifer system consists of a thick wedge of unconsolidated to consolidated clastic and carbonate rocks of Cretaceous to Holocene age. These rocks extend and thicken seaward from the inner Coastal Plain margin to the Atlantic Ocean, Gulf of Mexico, or Florida peninsula. Except where they are covered by younger strata, the aquifers and confining units that comprise the Southeastern Coastal Plain regional aquifer system crop out in adjacent bands from Mississippi to South Carolina. In outcrop areas, most of the water that enters the aquifer system discharges to nearby streams, the remainder of the recharge moves downgradient and enters the deeper, confined aquifer system. In gulfward areas, deeply buried clastic and carbonate rocks of Jurassic and Early Cretaceous age contain saline water and were not considered part of the studied aquifer system. In landward areas, the aquifer system is underlain by metamorphic, sedimentary and igneous rocks of Palezoic and early Mesozoic age having very low permeability and also were not considered part of the aquifer system. In summary, the lower limit of the Southeastern Coastal Plain aquifer system is delineated at the freshwater-saltwater interface in the gulfward areas, or overlies the very low permeability rocks of Palezoic and early Mesozoic age in landward areas.

The sediments of the Southeastern Coastal Plain are the product of cyclical advance and retreat of ancient seas. The fluctuating depositional conditions, resulting from regional uplift, subsidence, and sea-level changes caused the lithology and hydraulic properties of these sediments to differ greatly from place to place. These variations significantly affect the occurrence and flow of ground water.

Pumping from the Southeastern Coastal Plain aquifer system has caused only local waterlevel declines, and degradation of ground-water quality due to upconing or saltwater encroachment occurs only in restricted areas. The clastic sediments that comprise the Southeastern Coastal Plain regional aquifer system have been grouped into seven major hydrogeologic units. Regional and subregional computer models of the aquifer system were used to simulate ground-water flow, to help estimate predevelopment potentiometric surfaces and hydraulic properties of the aquifers and confining units, to assist in describing chemical evolution and quality of ground water and to test the validity of the conceptual hydrogeologic framework. The study was started in 1979 and completed in 1988, and has completed 61 reports as listed below.

1. Aucott, W.R., 1988, The predevelopment ground-water flow system and hydrologic characteristics of the Coastal Plain aquifers of South Carolina: U.S. Geological Survey WaterResources Investigations Report 86-4347, 66 p.

2. Aucott, W.R., Davis, M.E., and Speiran, G.K., 1987, Geohydrologic framework of the Coastal Plain aquifers of South Carolina: U.S. Geological Survey Water-Resources Investigations Report 85-4271, scale 1:1,000,000, 7 sheets.

3. Aucott, W.R., Meadows, R.S., and Patterson, G.G., 1987, Regional ground-water discharge to large streams in upper Coastal Plain of South Carolina and parts of North Carolina and Georgia: U.S. Geological Survey Water-Resources Investigations Report 86-4332, 28 p. 
4. Aucott, W.R., and Newcome, Roy, Jr., 1986, Selected aquifer-test information for the Coastal Plain aquifers of South Carolina: U.S. Geological Survey Water-Resources Investigations Report 86-4159, 30 p.

5. Aucott, W.R., and Speiran, G.K., 1984, Water-level measurements for the Coastal Plain aquifers of South Carolina prior to development: U.S. Geological Survey Open-File Report $84-803,5$ p.

6. 1985a, Potentiometric surfaces of the Coastal Plain aquifers of South Carolina prior to development: U.S. Geological Survey Water-Resources Investigations Report 84-4208, scale $1: 1,000,000,5$ sheets.

7. 1984b, Potentiometric surfaces of November 1982 and declines in the potentiometric surfaces between the period prior to development and November 1982 for the Coastal Plain aquifers of South Carolina: U.S. Geological Survey Water-Resources Investigations Report $84-4215$, scale $1: 1,000,000,7$ sheets.

8. 1985c, Ground water flow in the Coastal Plain aquifers of South Carolina: Ground Water, v. 23, no. 6, p. 736-745.

9. 1985d, Geohydrology and water quality of the Coastal Plain aquifers of South Carolina, in McGill, H.J., and Stone, P.A., eds., Symposium on Ground Water and Environmental Hydrogeology in South Carolina: South Carolina State Department of Health and Environmental Control, Columbia, South Carolina, October 1-2, 1985, Proceedings, p. 26-50.

10. Barker, R.A., 1986, Preliminary results of a steady-state ground-water flow model of the Southeastern Coastal Plain regional aquifer system: National Water Well Association Southern Regional Ground Water Conference, San Antonio, Texas, September 18-19, 1985, Proceedings, p. 315-338.

11. Barker, R.A., and Pernik, Maribeth, in press, Regional hydrogeology and simulation of deep ground-water flow in the Southeastern Coastal Plain aquifer system in parts of Mississippi, Alabama, Georgia, and South Carolina: U.S. Geological Survey Professional Paper 1410-C.

12. Crownover, J.E., 1987, Compilation and estimation of pumpage for the major groundwater users in the Coastal Plain of Alabama, 1960-85: U.S. Geological Survey Open-File Report $86-547,35 \mathrm{p}$.

13. Davis, M.E., 1988, Stratigraphic and hydrogeologic framework of the Alabama Coastal Plain: U.S. Geological Survey Water-Resources Investigations Report 87-4112, 39 p.

14. Davis, M.E., Sparkes, A.K., and Peacock, B.S., 1983, Results of a test well in the Nanafalia Formation near Melvin, Choctaw County, Alabama: U.S. Geological Survey Water-Resources Investigations Report 82-4108, 17 p.

15. Darden, Daphne, 1984, Potentiometric map of the Gordo aquifer in northeastern Mississippi, November and December 1982: U.S. Geological Survey Water-Resources Investigations Report $83-4254,1$ over-size sheet.

16. 1985a, Potentiometric map of the Eutaw-McShan aquifer in northeastern Mississippi, fall 1982: U.S. Geological Survey Water-Resources Investigations Report 85-4042, 1 oversize sheet. 
17. 1985b, Potentiometric map of the Ripley aquifer in northeastern Mississippi, fall 1982: U.S. Geological Survey Water-Resources Investigations Report 85-4041, 1 over-size sheet.

18. 1986, Potentiometric map of the lower Wilcox aquifer in Mississippi, fall 1982: U.S. Geological Survey Water-Resources Investigations Report 85-4059, 1 over-size sheet.

19. Faye, R.E., and Mayer, G.C., 1990, Ground-water flow and stream-aquifer relations in the northern Coastal Plain of Georgia and adjacent parts of Alabama and South Carolina: U.S. Geological Survey Water-Resources Investigations Report 88-4143, 83 p.

20. in press, Simulation of ground-water flow in Southeastern Coastal Plain clastic aquifers in Georgia and adjacent parts of Alabama and South Carolina: U.S. Geological Survey Professional Paper 1410-F.

21. Faye, R.E., and McFadden, K.W., 1986, Hydraulic characteristics of Upper Cretaceous and Lower Tertiary clastic aquifers--eastern Alabama, Georgia, and western South Carolina: U.S. Geological Survey Water-Resources Investigations Report 86-4210, 22 p.

22. Faye, R.E., and Prowell, D.C., 1982, Effects of late Cretaceous and Cenozoic faulting on the geology and hydrology of the Coastal Plain near the Savannah River, Georgia and South Carolina: U.S. Geological Survey Open-File Report 82-156, 73 p.

23. Feder, G.L., and Lee, R.W., 1981, Water-quality reconnaissance of Cretaceous aquifers in the Southeastern Coastal Plain: U.S. Geological Survey Open-File Report 81-696, 10 p.

24. Habib, Daniel, and Miller, J.A., 1989, Dinoflagellate species and organic facies evidence of marine transgression and regression in the Atlantic Coastal Plain: Palaeogeography, Palaeoclimatology, Palaeoecology, v. 74, p. 23-47.

25. Lee, R.W., 1984, Ground-water quality data from the Southeastern Coastal Plain, Mississippi, Alabama, Georgia, South Carolina and North Carolina: U.S. Geological Survey Open-File Report 84-237, 20 p.

26. 1985a, Geochemistry of groundwater in Cretaceous sediments of the Southeastern Coastal Plain of eastern Mississippi and western Alabama: Water Resources Research, v. 21, no. 10 , p. 1545-1556.

27. 1985b, Water-quality maps for selected Upper Cretaceous water-bearing zones in the Southeastern Coastal Plain: U.S. Geological Survey Water-Resources Investigations Report $85-4193$, scale 1:2,000,000, 2 sheets.

28.

1988a, Water-quality maps for the Upper Cretaceous and Lower Tertiary aquifer in the Southeastern Coastal Plain of Mississippi, Alabama, Georgia, South Carolina and southeastern North Carolina: U.S. Geological Survey Water-Resources Investigations Report 86-4116, scale $1: 2,000,000,2$ sheets.

29. 1988b, Water-quality maps for the Middle Tertiary aquifer in the Southeastern Coastal Plain of Mississippi, Alabama, Georgia, and South Carolina: U.S. Geological Survey WaterResources Investigations Report 86-4117, scale 1:2,000,000, 2 sheets.

30. in press, Geochemistry of ground water in the Southeastern Coastal Plain aquifer system in parts of Mississippi, Alabama, Georgia, and South Carolina: U.S. Geological Survey Professional Paper 1410-D. 
31. Lee, R.W., DeJarnette, S.S., and Barker, R.A., 1986, Distribution and altitude of the top of saline ground water in the Southeastern Coastal Plain: U.S. Geological Survey Water-Resources Investigations Report 85-4109, scale 1:2,000,000.

32. Lee, R.W., and Strickland, D.J., 1988, Geochemistry of groundwater in Tertiary and Cretaceous sediments of the Southeastern Coastal Plain in eastern Georgia, South Carolina, and southeastern North Carolina: Water Resources Research, v. 24, no. 12, p. 291-303.

33. Mallory, M.J., 1985, A new conceptual model of the flow system in the Cretaceous sand aquifers of Mississippi: Mississippi Water Resources Research Institute Mississippi Water Resources Conference, 5th, Proceedings, p. 19-22.

34. 1987, A proposed alternative hypothesis of unstressed flow in the Cretaceous sand aquifers of Alabama and Mississippi: American Institute of Hydrology, Hydrological Science and Technology, Short Papers in Hydrology, v. 3, no. 1-2, p. 61-66.

35. in press, Hydrogeology of the Southeastern Coastal Plain aquifer system in parts of eastern Mississippi and western Alabama: U.S. Geological Survey Professional Paper 1410-G.

36. Miller, J.A., 1988, Hydrogeology of Coastal Plain rocks, in Back, William, Rosenshein, J.S., and Seaber, P.R., eds, Hydrogeology: Boulder, Colorado, Geological Society of America, Geology of North America, v. O-2, p. 315-322.

37. in press, Summary of the hydrology of the Southeastern Coastal Plain aquifer system in Mississippi, Alabama, Georgia, and South Carolina: U.S. Geological Survey Professional Paper 1410-A.

38. Miller, J.A., Barker, R.A., and Renken, R.A., 1987, Hydrogeology of the Southeastern Coastal Plain aquifer system--an overview: in Vecchioli, John, and Johnson, A.I., eds., Regional Aquifer Systems of the United States, Aquifers of the Atlantic and Gulf Coastal Plain: American Water Resources Association Monograph Series, no. 9, p. 53-77.

39. Miller, J.A., and Renken, R.A., 1988, Nomenclature of regional hydrogeologic units of the Southeastern Coastal Plain aquifer system: U.S. Geological Survey Water-Resources Investigations Report 87-4202, 21 p.

40. Pernik, Maribeth, 1987, Sensitivity analysis of a multilayer, finite-difference model of the Southeastern Coastal Plain aquifer system--Mississippi, Alabama, Georgia, and South Carolina: U.S. Geological Survey Water-Resources Investigations Report 87-4108, 53 p.

41. Planert, Michael, and Sparkes, S.L., 1985, Estimation of vertical hydraulic conductivity of the clay layer between the Eutaw and Gordo aquifers in the vicinity of Faunsdale and Marengo Counties, Alabama: U.S. Geological Survey Water-Resources Investigations Report $85-4083,23 \mathrm{p}$.

42. Reid, M.S., Aucott, W.R., Lee, R.W., and Renken, R.A., 1986, Hydrologic and geologic analysis of a well in Dorchester County, South Carolina: U.S. Geological Survey WaterResources Investigations Report 86-4161, 23 p.

43. Reid, M.S., Renken, R.A., Wait, R.L., Aucott, W.R., and Lee, R.W., 1986, Hydrologic and geologic analysis of two wells in Marion County, South Carolina: U.S. Geological Survey Water-Resources Investigations Report 86-4102, 20 p. 
44. Renken, R.A., 1984, The hydrogeologic framework for the Southeastern Coastal Plain aquifer system of the United States: U.S. Geological Survey Water-Resources Investigations Report 84-4243, 26 p.

45. __ in press, Hydrogeology of the Southeastern Coastal Plain aquifer system in Mississippi, Alabama, Georgia, and South Carolina: U.S. Geological Survey Professional Paper 1410-B.

46. Renken, R.A., Barker, R.A., and Gomez-Gomez, Fernando, in press, Basin analysis, paleoenvironment reconstruction and tectonic structures--application of geologic interpretations to groundwater assessment in large sedimentary basins: International Association of Hydrogeologists International Conference on Groundwater in Large Sedimentary Basins, July 9-13, 1990, Perth, Australia.

47. Renken, R.A., Mahon, G.L., and Davis, M.E., 1989, Hydrogeology of clastic Tertiary and Cretaceous regional aquifers and confining units in the Southeastern Coastal Plain aquifer system of the United States: U.S. Geological Survey Hydrologic Investigations Atlas HA-701, scale $1: 250,000,3$ sheets.

48. Speiran, G.K., 1987, Relation of aqueous geochemistry to sediment depositional environment, Middendorf aquifer, South Carolina: in Vecchioli, John, and Johnson, A.I., eds., Regional Aquifer Systems of the United States, Aquifers of the Atlantic and Gulf Coastal Plain: American Water Resources Association Monograph Series, no. 9, p. 79-96.

49. Speiran, G.K., and Aucott, W.R., 1991, Effects of sediment depositional environment and ground-water flow on the quality and geochemistry of water in aquifers in sediments of Cretaceous age in the Coastal Plain of South Carolina: U.S. Geological Survey Open-File Report 91-202, 80 p.

50. Stricker, V.A., 1983, Base flow of streams in the outcrop area of the Southeastern sand aquifer--South Carolina, Georgia, Alabama, and Mississippi: U.S. Geological Survey WaterResources Investigations Report 83-4106, 17 p.

51. Stricker, V.A., Aucott, W.R., Faye, R.E., Williams, J.S., and Mallory, M.J., 1985a, Approximate potentiometric surface for the aquifer unit A2, Southeastern Coastal Plain aquifer system of the United States, prior to development: U.S. Geological Survey Water-Resources Investigations Report 85-4019, scale 1:2,000,000.

52. 1985b, Approximate potentiometric surface for the aquifer unit A3, Southeastern Coastal Plain aquifer system of the United States, prior to development: U.S. Geological Survey Water-Resources Investigations Report 85-4031, scale 1:2,000,000.

53. 1985c, Approximate potentiometric surface for the aquifer unit A4, Southeastern Coastal Plain aquifer system of the United States, prior to development: U.S. Geological Survey Water-Resources Investigations Report 84-4364, scale 1:2,000,000.

54. Strickland, D.J., and Mahon, G.L., 1986, Altitude of the freshwater-saltwater interface in a regionally extensive Coastal Plain aquifer of Mississippi, Alabama, and Georgia: U.S. Geological Survey Water-Resources Investigations Report 86-4058, scale 1:2,000,000.

55. Wait, R.L., and Davis, M.E., 1986, Configuration and hydrology of the pre-Cretaceous rocks underlying the Southeastern Coastal Plain aquifer system: U.S. Geological Survey WaterResources Investigations Report 86-4010, scale 1:2,000,000. 
56. Wait, R.L., Renken, R.A., Barker, R.A., Lee, R.W., and Stricker, V.A., 1986, Southeastern Coastal Plain regional aquifer-system study, in Sun, R.J., ed., Regional AquiferSystem Analysis Program of the U.S. Geological Survey--summary of projects, 1978-84: U.S. Geological Survey Circular 1002, p. 205-222.

57. Williams, J.S., DeJarnette, S.S., and Planert, Michael, 1986, Potentiometric surface and water use map of the Tuscaloosa aquifer in Alabama, fall 1982: U.S. Geological Survey WaterResources Investigations Report 85-4174, scale 1:1,000,000.

58. Williams, J.S., Planert, Michael, and DeJarnette, S.S., 1986a, Potentiometric surface, ground-water withdrawals, and recharge area for the Eutaw aquifer in Alabama, fall 1982:

U.S. Geological Survey Water-Resources Investigations Report 86-4121, scale 1:1,000,000.

59. 1986b, Potentiometric surface, ground-water withdrawals, and recharge area for the Providence-Ripley aquifer in Alabama, fall 1982: U.S. Geological Survey Water-Resources Investigations Report 86-4118, scale 1:1,000,000.

60 . $1986 \mathrm{c}$, Potentiometric surface, ground-water withdrawals, and recharge area for the Nanafalia-Clayton aquifer in Alabama, fall 1982: U.S. Geological Survey Water-Resources Investigations Report 86-4119, scale 1:1,000,000.

61. 1986d, Potentiometric surface, ground-water withdrawals, and recharge area for the Lisbon aquifer in Alabama, fall 1982: U.S. Geological Survey Water-Resources Investigations Report 86-412, scale 1:1,000,000. 


\section{COMPLETED REGIONAL AQUIFER-SYSTEM ANALYSIS STUDIES FOR \\ WHICH ADDITIONAL REPORTS ARE IN PREPARATION OR IN REVIEW}

\section{Caribbean Islands}

The study area of the Caribbean Islands regional aquifer-system analysis covers Puerto Rico, its adjacent islands (Vieques, Culebra, and Mona), and the U.S. Virgin Islands (St. Croix, St. Thomas, and St. John). The most important ground-water areas in Puerto Rico are the limestone aquifers of the north coast and the alluvial/fan delta aquifers of the south coast. The Kingshill aquifer of St. Croix is the only aquifer of significant extent in the U.S. Virgin Islands and is comprised of the Kingshill Limestone and unnamed limestone of Pliocene age. The investigation of the Caribbean Islands regional aquifer-system analysis study therefore was concentrated on these aquifers.

The Island of Puerto Rico has an area of about 3,300 square miles, flanked by foothills and east-to-west mountain ranges. The mountain ranges have a maximum altitude of about 4,400 feet and separate the northern and southern sides of the island. Extensive coastal plains as much as 8 miles wide are present along the north and south coasts. Rainfall ranges from 200 inches in the rain forests of the northeast to 35 inches in the lowlands of the southwest. The annual average rainfall on the island is about 75 inches.

The geology of Puerto Rico is complex and varied. The central core of the island consists largely of volcanic and intrusive rocks of Cretaceous and early Tertiary age. Limestones, minor dolomite and clastic sediments of Oligocene to Pliocene age were deposited to the north and south of the central mountain core. The clastic sediments consist of poorly sorted mixtures of gravel, sand, and fine-grained materials. On the north coast, minor clastic sediments grade upward into thick beds of relatively pure limestone. Ground water moving through joints and fractures in the limestone has formed solution and cavities. In outcrop areas along the north coast, a mature karst topography has developed. Along the south coast, conglomeratic gravel, sand, mudstone and limestone beds of Oligocene to Pliocene age do not represent an important source of ground water. Calcareous cement has effectively reduced the porosity of clastic strata and limestone beds have not undergone extensive solution diagenesis. Overlying gravel, sand and silt fan delta (coastal alluvial fan) deposits and river alluvium of Pleistocene to Holocene age represent the principal aquifer. Permeability of the aquifer is related to the depositional pattern of sand and gravel.

The Island of St. Croix, with an area of 82 square miles, is bordered to the northwest and east by low mountains and hills underlain by Cretaceous volcanic clastic and minor igneous rocks. The northwestern and eastern parts of the island are separated by a central graben ( 30 square miles) filled with deep-water marl and limestone of Miocene age. Shallow-water limestone occurs in a restricted area north of Kraus Lagoon. Alluvial deposits of Pliestocene to Holocene age blanket many parts of the central graben. The alluvial deposits are less than 20 feet, except where they infill over-deepened stream courses locally exceeding 100 feet. Alluviums are only local aquifers, but serve as temporary storage for rainfall recharge, and slowly release water to the Kingshill aquifer.

The Caribbean Islands regional aquifer-system analysis study was started in 1984 and completed in 1990 . The objectives of the study were to understand the hydrogeologic framework and geochemistry of the ground-water flow system, the potential for seawater encroachment near coastal areas, and the effects of changes in irrigation in the south coast of Puerto Rico. The study has completed 22 reports as listed below. However, as of May 1991, additional reports are still in preparation or in review. 
1. Dacosta, Rafael, and Gomez-Gomez, Fernando, 1987, Potentiometric surface of the alluvial aquifer and hydrologic conditions in the Guayama quadrangle, Puerto Rico, March 1987: U.S. Geological Survey Water Resources Investigations Report 87-4162, scale 1:20,000.

2. Gill, Ivan, in press, Geochemical controls on porosity in the St. Croix carbonate aquifer system, in Gomez-Gomez, Fernando, Quinones-Aponte, Vicente, and Johnson, A.I., eds, Regional Aquifer Systems of the United States, Aquifers of the Caribbean Islands: American Water Resources Association Monograph Series, no. 15.

3. Gomez-Gomez, Fernando, 1986, Caribbean Islands regional aquifer-system study, in Sun, R.J., ed., Regional Aquifer-System Analysis Program of the U.S. Geological Survey--summary of projects, 1978-84: U.S. Geological Survey Circular 1002, p. 234-241.

4. U.S. Geological Survey Water-Resources Investigations Report 86-4074, 50 p.

5. in press, Hydrochemistry of the south coastal plain aquifer system of Puerto Rico and its relation to surface water recharge, in Gomez-Gomez, Fernando, Quinones-Aponte, Vicente, and Johnson, A.I., eds, Regional Aquifer Systems of the United States, Aquifers of the Caribbean Islands: American Water Resources Association Monograph Series, no. 15.

6. Quinones-Aponte, Vicente, 1989, Horizontal anisotropy of the principal ground-water flow zone in the Salinas alluvial fan, Puerto Rico: Ground-Water, v. 27, no. 4, p. 491-500.

7. isotropic analytical models: American Institute of Hydrology Recent Advances in Ground-Water Hydrology, p. 349-357.

8. in press, Water resources development and its influence on the water budget for the aquifer system in the Salinas to Patillas area, Puerto Rico, in Gomez-Gomez, Fernando, QuinonesAponte, Vicente, and Johnson, A.I., eds, Regional Aquifer Systems of the United States, Aquifers of the Caribbean Islands: American Water Resources Association Monograph Series, no. 15.

9. Quinones-Aponte, Vicente, and Gomez-Gomez, Fernando, 1987, Potentiometric surface of the alluvial aquifer and hydrologic conditions in the Salinas quadrangle, Puerto Rico, March, 1986: U.S. Geological Survey Water Resources Investigations Report 87-4161, scale 1:20,000.

10. Renken, R.A., Barker, R.A., and Gomez-Gomez, Fernando, in press, Basin analysis, paleoenvironment reconstruction and tectonic structures--application of geologic interpretations to regional groundwater assessment in large sedimentary basins: International Association of Hydrogeologists International Conference on Groundwater in Large Sedimentary Basin, July 9-13, 1990, Perth, Australia.

11. Renken, R.A., Diaz, Pedro, Gomez-Gomez, Fernando, and Quinones-Aponte, Vicente, 1990, A hydrologic excursion to Puerto Rico's Southern Plain: U.S. Geological Survey OpenFile Report 90-365, 24 p.

12. Renken, R.A., Gomez-Gomez, Fernando, Quinones-Aponte, Vicente, and Dacosta, Rafael, in press, Structure and depositional patterns and their influence on the hydraulic conductivity of fan deltas in southern Puerto Rico; Houston, Texas, Earth Science Series, Circum-Pacific Council for Energy and Mineral Resources Conference on Energy and Mineral Potential of the Central America-Caribbean Region, March 6-9, 1989, San Jose, Costa Rica; reprinted in American Water Resources Association Monograph Series, no. 15. 
13. Rodriguez-del-Rio, Felix, and Gomez-Gomez, Fernando, 1989, Potentiometric surface of the aquifer and hydrologic conditions in the Santa Isabel-Juana Diaz area, Puerto Rico, March-April, 1987: U.S. Geological Survey Resources Investigations Report 89-4116, scale 1:20,000.

14. Rodriguez-del-Rio, Felix and Quinones-Aponte, Vicente, 1989, Potentiometric surface of the aquifer and hydrologic conditions in the Ponce-Juana Diaz area, Puerto Rico, April-May, 1987: U.S. Geological Survey Resources Investigations Report 89-4115, scale 1:20,000.

15. Rodriquez-Martinez, Jesus, in press, The hydrogeologic framework of the northern coastal province aquifer system of Puerto Rico, in Gomez-Gomez, Fernando, Quinones-Aponte, Vicente, and Johnson, A.I., eds, Regional Aquifer Systems of the United States, Aquifers of the Caribbean Islands: American Water Resources Association Monograph Series, no. 15.

16. Roman-Mas, Angel, and Ramos-Gines, Orlando, 1988, Compilation of water quality data for the North Coast Limestone aquifers, Puerto Rico, 1951-1987: U.S. Geological Survey Open-File Report 87-533, 133 p.

17. Roman-Mas, Angel, and Lee, R.W., 1987, Geochemical evolution of water within the North Coast Limestone aquifers of Puerto Rico--a conceptualization based on a sample flow path in the Barceloneta area: U.S. Geological Survey Water-Resources Investigations Report 86-4080, 28 p.

18. Torres-Gonzalez, Sigfredo, 1989, Compilation of ground-water level measurements obtained by the U.S. Geological Survey in Puerto Rico, 1958-1985: U.S. Geological Survey Open-File Report 88-701, 163 p.

19. in press, Steady-state simulation of ground-water flow conditions in the Kingshill aquifer, St. Croix, U.S. Virgin Islands, in Gomez-Gomez, Fernando, Quinones-Aponte, Vicente, and Johnson, A.I., eds., Regional Aquifer Systems of the United States, Aquifers of the Caribbean Islands: American Water Resources Association Monograph Series, no. 15.

20. Torres-Gonzalez, Sigfredo, and Gomez-Gomez, Fernando, 1987, Potentiometric surface of the alluvial aquifer and hydrologic conditions in the Central Aquirre quadrangle, Puerto Rico, March 1986: U.S. Geological Survey Water Resources Investigations Report 87-4160, scale $1: 20,000$.

21. Torres-Gonzalez, Sigfredo, and Rodriguez-Del-Rio, Felix, 1989, Potentiometric surface of the Kingshill aquifer and hydrologic conditions in St. Croix, U.S. Virgin Islands, July 1987: U.S. Geological Survey Water Resources Investigations Report 89-4085, scale 1:24,000.

22. Ward, W.C., Sharlach, R.A., and Hartley, J.R., in press, Controls on porosity and permeability in subsurface Tertiary carbonate rocks of northern Puerto Rico, in Gomez-Gomez, Fernando, Quinones-Aponte, Vicente, and Johnson, A.I., eds., Regional Aquifer Systems of the United States, Aquifer of the Caribbean Islands: American Water Resources Association Monograph Series, no. 15.

\section{Central Valley, California}

The Central Valley of California is approximately 20,000 square miles. The northern part is drained by the Sacramento River; and the southern part is drained partly by the San Joaquin River and also contains an internal drained basin - the Tulare Basin. The aquifer system of the Central Valley is composed of a heterogeneous mixture of continental alluvial materials derived 
from the surrounding mountains. Thickness of the sediments averages about 1,500 feet in the Sacramento Valley and 2,900 feet in the San Joaquin Valley.

The climate of the Central Valley is arid to semiarid, with average annual precipitation ranging from 14 to 20 inches in the Sacramento Valley, and 5 to 14 inches in the San Joaquin Valley. Under predevelopment conditions, potential evapotranspiration exceeded precipitation by as much as 40 inches per year. Consequently, large quantities of water are needed to support the valley's main industry and agricultural irrigation.

In addition to the agricultural use of ground water, nearly every city in the San Joaquin Valley uses ground water as the principal source for municipal and industrial supplies. Fortunately, ground water is available everywhere in the Central Valley, even where very little rain normally falls on the valley floor or little surface water exists. Annual pumpage in the Central Valley has increased from about 362,000 acre-feet during 1912-13 to about 15 million acre-feet during the drought in 1977. In parts of the Central Valley, pumping has caused water-level declines of nearly 400 feet.

About 50 percent of the thickness of continental sediments in the Central Valley is composed of clay and silt. As water levels decline in aquifers, water stored in the pores of the fine-grained confining layers start to drain into the adjacent aquifers where heads have been reduced by pumping. As a result, the land surface has subsided due to inelastic compaction of the fine-grained sediments. By 1970, subsidence exceeded 29 feet in one place in the San Joaquin Valley, and more than 5,000 square miles of land surface in the Central Valley had subsided more than 1 foot.

Because of these problems, water managers need accurate information on the behavior of the ground-water flow system in the Central Valley and on the potential effects of development on the aquifer system. To provide such needed information, the U.S. Geological Survey started a study of the regional aquifer-system of the Central Valley in 1978. The study was conducted in two phases. During phase I (completed in 1982), the geohydrologic framework of the aquifer system was defined and computer models of ground-water flow and land subsidence were developed and evaluated. All reports resulting from phase I are either published or in press. Phase II of the study was completed in 1990, and additional reports are still in preparation or in review. The principal objectives of phase II study were to conduct geochemical investigations and to evaluate the mobility of selenium in the San Joaquin Valley. As of May 1991, the Central Valley regional aquifer-system analysis study has completed 59 reports as listed below.

1. Beard, Sherrill, and Laudon, Julie, 1988, Data for ground-water test holes in Fresno County, western San Joaquin Valley, California, August to June 1985: U.S. Geological Survey Open-File Report 88-78, 39 p.

2. Belitz, Kenneth, and Heimes, F.J., 1990, Character and evolution of the ground-water flow system in the central part of the western San Joaquin Valley, California: U.S. Geological Survey Water-Supply Paper 2348, 28 p.

3. Berkstresser, C.F., Jr., French, J.J., and Schaal, M.E., 1985, Data for four geologic test holes in the Sacramento Valley, California: U.S. Geological Survey Open-File Report $85-488,110 \mathrm{p}$.

4. Bertoldi, G.L., 1979, A plan to study the aquifer system of the Central Valley of California: U.S. Geological Survey Open-File Report 79-1480, 48 p. Reprinted in Pacific Ground Water Digest, July-August 1980. 
1981: American Society of Civil Engineers Specialty Conference, San Francisco, California, August 10-14, 1981, Proceedings, v. 2, p. 1120-1128.

6. Survey Open-File Report 89-251, 2 p.

7. Bertoldi, G.L., Johnston, R.H., and Evenson, K.D., 1991, Ground water in the Central Valley, California--A summary report: U.S. Geological Survey Professional Paper 1401-A, 44 p.

8. Bertoldi, G.L., and Sun, R.J., 1986, Central Valley regional aquifer-system study, California, in Sun, R.J., ed., Regional Aquifer-System Analysis Program of the U.S. Geological Survey-summary of projects, 1978-84: U.S. Geological Survey Circular 1002, p. 9-16.

9. Burkham, D.E., and Guay, Richard, 1981, Development of curves that represent trends in selected hydraulic variables for the Sacramento River at Butte City, California: U.S. Geological Survey Open-File Report 81-693, 22 p.

10. Deverel, S.J., 1988, Hydrologic processes affecting the distribution and mobility of salinity and selenium in shallow ground water, western San Joaquin Valley, California: American Society of Agronomy California Plant and Soil Conference, Fresno, California,1988, proceedings, p. 1-3.

11. 1988, Geohydrologic aspects of water-quality problems of the San Joaquin Valley, California: American Society of Civil Engineers National Irrigation and Drainage Division Conference on Planning Now for Irrigation and Drainage, Lincoln, Nebraska, July 18-21, 1991, Proceedings, p. 694-699.

12. 1989, Geostatistical and principal-component analyses of groundwater chemistry and soil-salinity data, San Joaquin Valley, California, in Stephen Ragone, ed., Regional Characterization of Water Quality: International Association of Hydrologic Science Publication no. 182, p. 11-18.

13. Deverel, S.J., and Fio, J.L., 1990, Ground-water flow and solute movement to drain laterals, western San Joaquin Valley, California. I. Geochemical assessment: U.S. Geological Survey Open-File Report 90-136, 23 p.

14. Deverel, S.J., and Fujii, Roger, 1988, Processes affecting the distribution of selenium in shallow groundwater of agricultural areas, western San Joaquin Valley, California: Water Resources Research, v. 24, no. 4, p. 516-524.

15. 1990, Chemistry of trace elements in soils and ground water, Chap. 4 in Tanji, K.K., ed., Agricultural Salinity Assessment and Management: American Society of Civil Engineers Manuals and Reports in Engineering Practice, no. 71, p. 64-90.

16. Deverel, S.J., and Gallanthine, S.K., 1989, Relation of salinity and selenium in shallow groundwater to hydrologic and geochemical processes, western San Joaquin Valley, California: Journal of Hydrology, v. 109, p. 125-149.

17. Deverel, S.J., and Millard, S.P., 1988, Distribution and mobility of selenium and other trace elements in shallow groundwater of the western San Joaquin Valley, California: Environmental Science and Technology, v. 22, no. 6, p. 697-702. 
18. Diamond, Jonathan, and Williamson, A.K., 1983, A summary of ground-water pumpage in the Central Valley, California, 1961-77: U.S. Geological Survey Water-Resources Investigations Report 83-4037, 70 p.

19. Dubrovsky, N.M., Neil, J.M., Fujii, Roger, Oremland, R.S., and Hollibaugh, J.T., 1990, Influence of redox potential on selenium distribution in ground water, Mendota, western San Joaquin Valley, California: U.S. Geological Survey Open-File Report 90-138, 24 p.

20. Dubrovksy, N.M., Neil, J.M., Welker, M.C., and Evenson, K.D., 1991, Geochemical relations and distribution of selected trace elements in ground water of the northern part of the western San Joaquin Valley, California: U.S. Geological Survey Open-File Report 90-108, 55 p.

21. Evenson, K.D., and Neil, J.M., 1986, Map of California showing distribution of selenium concentrations in wells sampled by the U.S. Geological Survey, 1975-85: U.S. Geological Survey Open-File Report 86-72, scale 1:1,000,000.

22. Farrar, C.D., and Bertoldi, G.L., 1988, Region 4, Central Valley and Pacific Coast Ranges, in Back, William, Rosenshein, J.S., and Seaber, P. R., eds, Hydrogeology: Boulder, Colorado, Geological Society of America, Geology of North America, v. O-2, p. 59-67.

23. Fio, J.L., and Deverel, S.J., 1990, Ground-water flow and solute movement to drain laterals, western San Joaquin Valley, California. II. Quantitative hydrologic assessment: U.S. Geological Survey Open-File Report 90-137, 15 p.

24. Fio, J.L., and Fujii, Roger, 1990, Selenium speciation methods and application to soil saturation extracts from San Joaquin Valley, California: Soil Science Society of America Journal, v. 54, no. 2, p. 363-369.

25. Fio, J.L., Fujii, Roger, and Deverel, S.J., 1990, Evaluation of selenium mobility in soil using sorption experiments and a numerical model, western San Joaquin Valley, California: U.S. Geological Survey Open-File Report 90-135, 13 p.

26. Fogelman, R.P., 1982a, Compilation of selected ground-water-quality data from the San Joaquin Valley, California: U.S. Geological Survey Open-File Report 82-335, 276 p.

27. 1982b, Dissolved-solids concentrations of ground water in the Sacramento Valley, California: U.S. Geological Survey Hydrologic Investigations Atlas HA-645, scale 1:250,000.

28. 1983, Ground-water quality in the Sacramento Valley, California--water types and potential nitrate and boron problem areas: U.S. Geological Survey Hydrologic Investigations Atlas HA-651, scale 1:250,000.

29. French, J.J., Page, R.W., and Bertoldi, G.L., 1982, Data for ground-water test hole near Zamora, Central Valley Aquifer Project, California: U.S. Geological Survey Open-File Report $82-510,72 \mathrm{p}$.

30. 1983, Data for ground-water test hole near Nicolaus, Central Valley Aquifer Project, California: U.S. Geological Survey Open-File Report 83-273, 60 p.

31. French, J.J., Page, R.W., Bertoldi, G.L., and Fogelman, R.P., 1983, Data for groundwater test hole near Butte City, Central Valley Aquifer Project, California: U.S. Geological Survey Open-File Report 83-697, 54 p. 
32. Fujii, Roger, and Deverel, S.J., 1989, Mobility and distribution of selenium and salinity in groundwater and soil of drained agricultural fields, western San Joaquin Valley of California, in Jacobs, L.W., and others, eds., Selenium in Agriculture and the Environment: Soil Science Society of America Special Publication no. 23, p. 195-212.

33. Fujii, Roger, Deverel, S.J., and Hatfield, D.B., 1988 Distribution of selenium in soils of agricultural fields, western San Joaquin Valley, California: Soil Science Society of America Journal, v. 52, no. 5, p. 1274-1283.

34. Gilliom, R.J., 1986, Central Valley regional aquifer system, California, phase II study, in Sun, R.J., ed., Regional Aquifer-System Analysis Program of the U.S. Geological Survey-summary of projects, 1978-84: U.S. Geological Survey Circular 1002, p. 248.

35 . 1987, Selenium in agricultural drainage water, San Joaquin Valley, California: U.S. Geological Survey Yearbook, Fiscal Year 1986, p. 29-32.

36. 1989, Selenium in the San Joaquin Valley--sources, distribution, and mobility: U.S. Geological Survey Yearbook, Fiscal Year 1988, p. 30-34.

37. Gilliom, R.J., Belitz, Kenneth, Deverel, S.J., Dubrovsky, N.M., and Fujii, Roger, 1989 , Preliminary assessment of sources, distribution, and mobility of selenium in the San Joaquin Valley, California: U.S. Geological Survey Water-Resources Investigations Report 88-4186, 129 p.

38. Gronberg, J.M., Belitz, Kenneth, and Phillips, S.P., 1990, Distribution of wells in the central part of the western San Joaquin Valley, California: U.S. Geological Survey WaterResources Investigations Report 89-4158, 51 p.

39. Hull, L.C., 1984, Geochemistry of ground water in the Sacramento Valley, California: U.S. Geological Survey Professional Paper 1401-B, 36 p.

40. Laudon, Julie, and Belitz, Kenneth, 1991, Texture and depositional history of Late Pleistocene-Holocene alluvium in the central part of the western San Joaquin Valley, California: Bulletin of the Association of Engineering Geologists, v. 28, no. 1, p. 73-88.

41. Mandle, R.J., and Kontis, A.L., 1986, Directions and rates of ground-water movement in the vicinity of Kesterson Reservoir, San Joaquin Valley, California: U.S. Geological Survey Water-Resources Investigations Report 86-4196, 57 p.

42. Mullen, J.R., and Nady, Paul, 1985, Water budgets for major streams in the Central Valley, California, 1961-77: U.S. Geological Survey Open-File Report 85-401, 87 p.

43. Nady, Paul, and Larragueta, L.L., 1983a, Development of irrigation in the Central Valley of California: U.S. Geological Survey Hydrologic Investigations Atlas HA-649, scale $1: 500,000,2$ sheets.

44. 1983b, Estimated average annual streamflow into the Central Valley of California: U.S. Geological Survey Hydrologic Investigations Atlas HA-657, scale 1:500,000.

45. Neil, J.M., 1986, Dissolved-selenium data for wells in the western San Joaquin Valley, California, February to July 1985: U.S. Geological Survey Open-File Report 86-73, 10 p. 
46. 1987, Data for selected pesticides and volatile organic compounds for wells in the western San Joaquin Valley, California, February to July 1985: U.S. Geological Survey OpenFile Report 87-48, 10 p.

47. Page, R.W., 1981, Data on depths to the upper Mya zone of the San Joaquin Formation in the Kettleman City area, San Joaquin Valley, California: U.S. Geological Survey Open-File Report 81-699, 12 p.

48. 1982, Texture maps, a guide to deep ground-water basins, Central Valley, California, in Water Forum 1981: American Society of Civil Engineers Specialty Conference, San Francisco, California, August 10-14, 1981, Proceedings, v. 2, p. 1114-1119.

49. 1983, Geology of the Tulare Formation and other continental deposits, Kettleman City area, San Joaquin Valley, California--with a section on ground-water management considerations and use of texture maps: U.S. Geological Survey Water-Resources Investigations Report $83-4000,24 \mathrm{p}$.

50. 1986, Geology of the fresh ground-water basin of the Central Valley, California, with texture maps and sections: U.S. Geological Survey Professional Paper 1401-C, 54 p.

51. Page, R.W., and Bertoldi, G.L., 1983, A Pleistocene diatomaceous clay and a pumiceous ash: California Geology, v. 36, no. 1, p. 14-20.

52. Phillips, S.P., and Belitz, Kenneth, 1990, Calibration of a textured-based model of a groundwater flow system, western San Joaquin Valley, California: U.S. Geological Survey Open-File Report 90-573, 30 p.

53. Prudic, D.E., and Williamson, A.K., 1986, Evaluation of a technique for simulating a compacting aquifer system in the Central Valley of California, U.S.A., in Johnson, A.I., Carbognin, Laura, and Ubertini, L., eds., Land Subsidence: International Symposium on Land Subsidence, 3rd, Venice, Italy, March 1984, Proceedings, International Association of Hydrological Sciences Publication 151, p. 53-63.

54. Shelton, L.R., and Miller, L.K., 1988, Water-quality data, San Joaquin Valley, California, March 1985 to March 1987: U.S. Geological Survey Open-File Report 88-479, 210 p.

55 . 1991, Water-quality data, San Joaquin Valley, California, April 1987 to September 1988: U.S. Geological Survey Open-File Report 91-74, 189 p.

56. Swain, L.A., 1982, Ground-water models of the Central Valley, in Water Forum 1981: American Society of Civil Engineers Specialty Conference, San Francisco, California, August 10-14, 1981, Proceedings, v. 2, p. 1129-1133.

57. Williamson, A.K., 1982, Evapotranspiration of applied water, Central Valley, California, 1957-78: U.S. Geological Survey Water-Resources Investigations Report 81-45, 56 p.

58. Williamson, A.K., and Prudic, D.E., 1986, Simulation of flow and compaction in the regional aquifer system of the Central Valley of California, U.S.A., in Johnson, A.I., Carbognin, Laura, and Ubertini, L., eds., Land Subsidence: International Symposium on Land Subsidence, 3rd, Venice, Italy, March 1984, Proceedings, International Association of Hydrological Sciences Publication 151, p. 271-280. 
59. Williamson, A.K., Prudic, D.E., and Swain, L.A., 1989, Ground-water flow in the Central Valley, California: U.S. Geological Survey Professional Paper 1401-D, 127 p.

\section{Central Midwest}

The Central Midwest regional aquifer-system analysis study covers an area of 370,000 square miles in parts of Arkansas, Colorado, Kansas, Missouri, Nebraska, New Mexico, Oklahoma, and Texas. Except in parts of Missouri, the sedimentary rocks underlying the study area are generally water-yielding formations that range in thickness from a featheredge in Missouri to more than 40,000 feet in central Oklahoma. The igneous and metamorphic basement rocks that underlie the water-yielding formations generally do not yield significant quantities of water to wells. Therefore, the surface of the basement rock forms the lower limit of the ground-water flow system in the study area.

Hydraulic properties of the various rocks in the study area differ greatly. In most of the study area, the water-yielding rocks are deeply buried, and ground-water related data are scarce except for data collected incidentally by the petroleum industry. Because the cost of collecting additional hydrologic data from the deep subsurface is prohibitive, special efforts and techniques were used to evaluate and analyze existing data.

The purpose of the Central Midwest regional aquifer-system analysis study is to provide hydrologic information needed for planning and managing development of the system and to evaluate the effects of development on the system. Potential development of the aquifer system include fresh-water supply, waste disposal, and geothermal potential. Potential effects of development on the system include decreasing water supply and deterioration of water quality. Although interpretation of regional hydraulics have potential implications regarding oil and gas occurrence and development, the oil and gas resource itself is not being appraised. The investigations of the Central Midwest regional aquifer-system analysis study was started in 1980 and completed in 1989. The study has completed 63 reports as listed below. As of May 1991, additional reports are still in preparation or in review.

1. Banta, E.R., 1985, The Dakota aquifer near Pueblo, Colorado--faults and flow patterns: U.S. Geological Survey Water-Resources Investigations Report 85-4186, 23 p.

2. Case, H.L., III, 1984, Aquifer utilization, in Jorgensen, D.G., and Signor, D.C., eds., Geohydrology of the Dakota Aquifer: National Water Well Association C.V. Theis Conferences on Geohydrology, 1st, Lincoln, Nebraska, October 5-6, 1982, Proceedings, p. 243-245.

3. Christenson, S.C., Morton, R.B., Havens, J.S., and Fairchild, R.W., 1988, Geologic logs for selected deep wells in parts of Oklahoma, Texas, and New Mexico: U.S. Geological Survey Open-File Report 86-541, 161 p.

4. Combs, L.J., Hansen, C.V., and Wolf, R.J., in press, Geohydrologic systems in Kansas-geohydrology of the lower aquifer unit in the Western Interior Plains Aquifer system: U.S. Geological Survey Hydrologic Investigations Atlas HA-722-I, scale 1:1,500,000, 3 sheets.

5. Dealy, M.T., Kume, Jack, and Jenkins, E.D., 1984, Hydrogeology and development of the Dakota aquifer in southwest Kansas, in Jorgensen, D.G., and Signor, D.C., eds., Geohydrology of the Dakota Aquifer: National Water Well Association C.V. Theis Conferences on Geohydrology, 1st, Lincoln, Nebraska, October 5-6, 1982, Proceedings, p. 209-220. 
6. Dugan, J.T., 1986, Hydrologic properties of soils in parts of Arkansas, Colorado, Kansas, Missouri, Nebraska, New Mexico, Oklahoma, South Dakota, and Texas: U.S. Geological Survey Hydrologic Investigations Atlas HA-678, scale 1:1,500,000.

7. Dugan, J.T., and Peckenpaugh, J.M., 1985, Effects of climate, vegetation, and soils on consumptive water use and ground-water recharge to the Central Midwest regional aquifer system, mid-continent United States: U.S. Geological Survey Water-Resources Investigations Report 85-4236, 78 p.

8. Ellis, M.J., 1984, Overview of the Dakota aquifer system in Nebraska, in Jorgensen, D.G., and Signor, D.C., eds., Geohydrology of the Dakota Aquifer: National Water Well Association C.V. Theis Conferences on Geohydrology, 1st, Lincoln, Nebraska, October 5-6, 1982, Proceedings, p. 48-55.

9. 1986, Hydrogeologic data for the Dakota aquifer system in Nebraska: U.S. Geological Survey Open-File Report 86-526, 100 p.

10. Freiwald, D.A., 1985, Average annual precipitation and runoff for Arkansas, 1951-80: U.S. Geological Survey Water-Resources Investigations Report 84-4363, scale 1:1,000,000.

11. 1987, Streamflow gain and loss of selected streams in northern Arkansas: U.S. Geological Survey Water-Resources Investigations Report 86-4185, scale 1:125,000, 4 sheets.

12. Hansen, C.V., Spinazola, J.M., and Wolf, R.J., in press, Geohydrologic systems in Kansas--physical framework of the lower aquifer unit in the Western Interior Plains aquifer system: U.S. Geological Survey Hydrologic Investigations Atlas HA-722-F, scale $1: 1,000,000,2$ sheets.

13. Hansen, C.V., Underwood, E.J., Wolf, R.J., and Spinazola, J.M., in press, Geohydrologic systems in Kansas--physical framework of the upper aquifer unit in the Western Interior Plains aquifer system: U.S. Geological Survey Hydrologic Investigations Atlas HA-722-D, scale $1: 1,000,000,2$ sheets.

14. Hansen, C.V., Wolf, R.J., and Spinazola, J.M., in press, Geohydrologic systems in Kansas--physical framework of the confining unit in the Western Interior Plains aquifer system: U.S. Geological Survey Hydrologic Investigations Atlas HA-722-E, scale 1:1,000,000, 2 sheets.

15. Hedman, E.R., and Engel, G.B., 1989, Flow characteristics for selected streams in the Great Plains subregion of the Central Midwest aquifer system and selected adjacent areas--Kansas and Nebraska, and parts of Colorado, Iowa, Missouri, New Mexico, Oklahoma, South Dakota, Texas, and Wyoming: U.S. Geological Survey Hydrologic Investigations Atlas HA-708, scale $1: 1,000,000,3$ sheets.

16. Hedman, E.R., and Jorgensen, D.G., 1990, Surface- and ground-water interaction and hydrologic budget of the Missouri River Valley aquifer between Yankton, South Dakota, and St. Louis, Missouri: U.S. Geological Survey Hydrologic Investigations Atlas HA-721, scale $1: 1,500,000$.

17. Hedman, E.R., Skelton, John, and Freiwald, D.A., 1987, Flow characteristics for selected springs and streams in the Ozark subregion, Arkansas, Kansas, Missouri, and Oklahoma:

U.S. Geological Survey Hydrologic Investigations Atlas HA-688, scale 1: 750,000, 4 sheets. 
18. Helgesen, J.O., and Hansen, C.V., 1989, Description of data files compiled for the Central Midwest regional aquifer-system analysis: U.S. Geological Survey Open-File Report 89-42, 37 p.

19. Helgesen, J.O., Jorgensen, D.G., Leonard, R.B., and Signor, D.C., 1982, Regional study of the Dakota aquifer (Darton's Dakota revisited): Ground Water, v. 20, no. 4, p. 410-414.

20. Helgesen, J.O., and Leonard, R.B., 1989, Geohydrology of the Great Plains aquifer system, central United States, in Swain, L.A., and Johnson, A.I., eds., Regional Aquifer Systems of the United States, Aquifers of the Midwestern Area: American Water Resources Association Monograph Series, no. 13, p. 179-190.

21. Helgesen, J.O., Leonard, R.B., and Wolf, R.J., in press, Hydrology of the Great Plains aquifer system in Nebraska, Colorado, Kansas, and adjacent areas: U.S. Geological Survey Professional Paper 1414-E.

22. Imes, J.L., 1989a, Major geohydrologic units in and adjacent to the Ozark Plateaus Province, Missouri, Arkansas, Kansas, and Oklahoma--basement confining unit: U.S. Geological Survey Hydrologic Investigations Atlas HA-711-B, scale 1:750,000.

23. 1989b, Geohydrology and hydrochemistry of the Ozark Plateaus aquifer system, in Swain, L.A., and Johnson, A.I., eds., Regional Aquifer Systems of the United States, Aquifers of the Midwestern Area: American Water Resources Association Monograph Series, no. 13 , p. $165-178$.

24. 1990a, Major geohydrologic units in and adjacent to the Ozark Plateaus Province, Missouri, Arkansas, Kansas, and Oklahoma: U.S. Geological Survey Hydrologic Investigations Atlas HA-711-A, scale 1:750,000.

25. 1990b, Major geohydrologic units in and adjacent to the Ozark Plateaus Province, Missouri, Arkansas, Kansas, and Oklahoma--St. Francois aquifer: U.S. Geological Survey Hydrologic Investigations Atlas HA-711-C, scale 1:750,000, 2 sheets.

26. 1990c, Major geohydrologic units in and adjacent to the Ozark Plateaus Province, Missouri, Arkansas, Kansas, and Oklahoma--St. Francois confining layer: U.S. Geological Survey Hydrologic Investigations Atlas HA-711-D, scale 1:750,000, 3 sheets.

27. 1990d, Major geohydrologic units in and adjacent to the Ozark Plateaus Province, Missouri, Arkansas, Kansas, and Oklahoma--Ozark aquifer: U.S. Geological Survey Hydrologic Investigations Atlas HA-711-E, scale 1:750,000, 3 sheets.

28. 1990e, Major geohydrologic units in and adjacent to the Ozark Plateaus Province, Missouri, Arkansas, Kansas, and Oklahoma--Ozark confining unit: U.S. Geological Survey Hydrologic Investigations Atlas HA-711-F, scale 1:750,000, 3 sheets.

29. 1990f, Major geohydrologic units in and adjacent to the Ozark Plateaus Province, Missouri, Arkansas, Kansas, and Oklahoma--Springfield Plateau aquifer: U.S. Geological Survey Hydrologic Investigations Atlas HA-711-G, scale 1:750,000, 3 sheets.

30. 1990g, Major geohydrologic units in and adjacent to the Ozark Plateaus Province, Missouri, Arkansas, Kansas, and Oklahoma--Western Interior Plains confining system: U.S. Geological Survey Hydrologic Investigations Atlas HA-711-H, scale 1:750,000, 3 sheets. 
31. Imes, J.L, and Davis, J.V., 1990a, Water type and concentration of dissolved solids, chloride, and sulfate in ground water from the St. Francois aquifer in Missouri: U.S.

Geological Survey Hydrologic Investigations Atlas HA-711-J, scale 1:750,000.

32. 1990b, Water type and concentration of dissolved solids, chloride, and sulfate in ground water from the Springfield Plateau aquifer in Missouri, Arkansas, Kansas, and Oklahoma: U.S. Geological Survey Hydrologic Investigations Atlas HA-711-L, scale 1:750,000, 2 sheets.

33. 1991, Water type and concentration of dissolved solids, chloride, and sulfate in ground water from the Ozark aquifer in Missouri, Arkansas, Kansas, and Oklahoma: U.S. Geological Survey Hydrologic Investigations Atlas HA-711-K, scale 1:750,000, 4 sheets.

34. Imes, J.L., and Emmett, L.F., in press, Geohydrology and modeling analysis of the Ozark Plateaus aquifer system in parts of Missouri, Arkansas, Oklahoma, and Kansas: U.S. Geological Survey Professional Paper 1414-F.

35. Imes, J.L., Smith, B.J., 1990, Areal extent, stratigraphic relation, and geohydrologic properties of regional geohydrologic units in southern Missouri: U.S. Geological Survey Hydrologic Investigations Atlas HA-711-I, scale 1:750,000, 3 sheets.

36. Jorgensen, D.G., 1984, Aquifer names, in Jorgensen, D.G., and Signor, D.C., eds., Geohydrology of the Dakota Aquifer: National Water Well Association C.V. Theis Conferences on Geohydrology, 1st, Lincoln, Nebraska, October 5-6, 1982, Proceedings, p. 4-7.

37. 1988a, Estimating permeability in water-saturated formations: The Log Analyst, November-December 1988, p. 401-409.

38. 1988b, Using geophysical logs to estimate porosity, water resistivity, and intrinsic permeability: U.S. Geological Survey Water-supply Paper 2321, 24 p.

39. 1989, Paleohydrology of the Anadarko Basin, central United States, in Johnson, K.S., ed., Anadarko Basin Symposium, 1988: Oklahoma State Geological Survey Circular 90, p. 176-193.

40. Jorgensen, D.G., in press, Aquifers as effected by diagenesis: U.S. Geological Survey Bulletin 1989-E.

41. _ in press, Paleohydrology of the Central United States: U.S. Geological Survey Bulletin 1989-D.

42. Jorgensen, D.G., Downey, Joe, Dutton, A.R., and Maclay, R.W., 1988, Central non-glacial plains, in Back, William, Rosenshein, J.S., and Seaber, P.R., eds., Hydrogeology: Boulder, Colorado, Geological Society of America, Geology of North America, v. O-2, p. 141-156.

43. Jorgensen, D.G., Gogel, Tony, and Signor, D.C., 1982, Determination of flow in aquifers containing variable density water: Ground Water Monitoring Review, v. 2, no. 2, p. 40-45.

44. Jorgensen, D.G., Helgesen, J.O., and Imes, J.L., in press, Regional aquifers in Kansas, Nebraska, and parts of Arkansas, Colorado, Missouri, New Mexico, Oklahoma, South Dakota, Texas, and Wyoming--geohydrologic framework: U.S. Geological Survey Professional Paper 1414-B. 
45. Jorgensen, D.G., Helgesen, J.O., Leonard, R.B., and Signor, D.C., 1985, Equivalent freshwater head and dissolved-solids concentration of water in rocks of Cambrian and Ordovician age and in rocks of Mississippian age in northern Midcontinent, U.S.A.: U.S. Geological Survey Miscellaneous Field Studies Map MF-1835-B, scale 1:1,000,000, 2 sheets.

46. Jorgensen, D.G., Leonard, R.B., Signor, D.C., and Helgesen, J.O., 1986, Central Midwest regional aquifer-system study, in Sun, R.J., ed., Regional Aquifer-System Analysis Program of the U.S. Geological Survey--summary of projects, 1978-84: U.S. Geological Survey Circular 1002, p. 132-140.

47. Jorgensen, D.G., and Signor, D.C., 1981, Plan of study for the Central Midwest regional aquifer-system analysis in parts of Arkansas, Colorado, Kansas, Missouri, Nebraska, New Mexico, South Dakota, and Texas: U.S. Geological Survey Water-Resources Investigations Report 81-206, 28 p.

48. 1984, editors, Geohydrology of the Dakota Aquifer: National Water Well Association C.V. Theis Conferences on Geohydrology, 1st, Lincoln, Nebraska, October 5-6, 1982, Proceedings, $247 \mathrm{p}$.

49. Jorgensen, D.G., Signor, D.C., and Imes, J.L., 1989a, Accounting for intracell flow in models with emphasis on water table recharge and stream-aquifer interaction. I. problems and concepts: Water Resources Research, v. 25, no. 4, 1989, p. 669-676.

50. 1989b, Accounting for intracell flow in models with emphasis on water table recharge and stream-aquifer interaction. II. a procedure: Water Resources Research, v. 25, no. 4, 1989, p. 677-684.

51. Kenny, J.F., Hansen, C.V., and Wolf, R.J., in press, Geohydrologic systems in Kansas-geohydrology of the upper aquifer unit in the Western Interior Plains aquifer system: U.S. Geological Survey Hydrologic Investigations Atlas HA-722-H, scale 1:1,500,000, 2 sheets.

52. Leonard, R.B., Signor, D.C., Jorgensen, D.G., and Helgesen, J.O., 1983, Geohydrology and hydrochemistry of the Dakota aquifer, central United States: American Water Resources Association Water Resources Bulletin, v. 19, no. 6, p. 903-911.

53. McGovern, H.E., 1984, Overview of the Dakota aquifer in Kansas, in Jorgensen, D.G., and Signor, D.C., eds., Geohydrology of the Dakota Aquifer: National Water Well Association C.V. Theis Conferences on Geohydrology, 1st, Lincoln, Nebraska, October 5-6, 1982, Proceedings, p. 58-61.

54. McGovern, H.E., and Wolf, R.J., in press, Geohydrologic systems in Kansas-geohydrology of the Great Plains aquifer system: U.S. Geological Survey hydrologic Investigations Atlas HA-722-G, scale 1:1,000,000, 2 sheets.

55. Parkhurst, R.S., and Christenson, S.C., 1987, Selected chemical analysis of water from formations of Mesozoic and Paleozoic ages in parts of Oklahoma, northern Texas, and Union County, New Mexico: U.S. Geological Survey Water-Resources Investigations Report 86-4355, 222 p.

56. Robson, S.G., and Banta, E.R., 1987, Geology and hydrology of deep bedrock aquifers in eastern Colorado: U.S. Geological Survey Water-Resources Investigations Report 85-4240, scale $1: 1,000,000,6$ sheets. 
57. Signor, D.C., 1985, Groundwater sampling during artificial recharge--equipment, techniques, and data analyses, in Asano, Takashi, ed., Artificial Recharge of Groundwater: Boston, Massachusetts, Butterworth Publishers, p. 151-202.

58. Signor, D.C., and Imes, J.L., 1989, Geohydrology of regional aquifer systems in Cretaceous and older rocks underlying the central United States, in Swain, L.A., and Johnson, A.I., eds., Regional Aquifer Systems of the United States, Aquifers of the Midwestern Area: American Water Resources Association Monograph Series, no. 13, p. 149-163.

59. Smith, B.J., and Imes, J.L., in press, Correlation of regional geohydrologic units to geologic formations in southern Missouri: U.S. Geological Survey Hydrologic Investigations Atlas HA-711-M, scale 1:750,000, 2 sheets.

60. Spinazola, J.M., Hansen, C.V., Underwood, E.J., Kenny, J.F., and Wolf, R.J., 1987, Index to selected machine-readable geohydrologic data for Precambrian through Cretaceous rocks in Kansas: U.S. Geological Survey Open-File Report 87-396, 31 p.

61. Spinazola, J.M., Wolf, R.J., and McGovern, H.E., in press, Geohydrologic systems in Kansas--physical framework of the Great Plains aquifer system: U.S. Geological Survey Hydrologic Investigations Atlas HA-722-B, scale 1:1,000,000 and 1:2,000,000, 2 sheets.

62. Wolf, R.J., Hansen, C.V., McGovern, H.E., and Spinazola, J.M., 1990, Geohydrologic systems in Kansas with emphasis on systems in Upper Cambrian through Lower Cretaceous rocks: U.S. Geological Survey Hydrologic Investigations Atlas HA 722-A, scale $1: 750,000,2$ sheets.

63. Wolf, R.J., McGovern, H.E., and Spinazola, J.M., in press, Geohydrologic systems in Kansas--physical framework of the Western Interior Plains confining system: U.S. Geological Survey Hydrologic Investigations Atlas HA-722-C, scale 1:1,000,000, 2 sheets.

\section{Columbia Plateau, Washington, Oregon, and Idaho}

The Columbia Plateau is located in central and eastern Washington, northern Oregon, and a small part of northwestern Idaho. The plateau covers about 63,200 square miles entirely within the drainage of the Columbia River. The Columbia Plateau regional aquifer-system analysis study consists of unconsolidated sediments, basaltic rocks, and intercalated sediments. Where saturated unconsolidated sediments overlie the basalts, it forms a water-table aquifer that is termed the overburden aquifer. This aquifer is the uppermost unit in the Columbia Plateau aquifer system. Rocks of the Miocene Columbia River Basalt Group make up most of the aquifer system underlying the Columbia Plateau. The many layers of lava beds and sedimentary interbeds form a multilayered aquifer system which, for study purposes, has been divided into three units. The units, including intercalated sediments, correspond to three basalt formations in the Columbia River Basalt Group--the Saddle Mountains, Wanapum, and Grande Ronde Basalts. The three basalt units are connected hydraulically either directly or through leaking confining sedimentary interbeds. The sedimentary interbeds between the units generally are fine grained and laterally extensive; the thickness of the interbeds is small compared to the thickness of the basalt units.

The four geohydrologic units (overburden aquifer and 3 basalt units) form the aquifer system underlying the Columbia Plateau and provide water for most municipal, industrial, and domestic needs; the units also provide water for most of the irrigated lands outside the Columbia Basin Irrigation Project area and the Yakima River Basin. Agriculture is the predominant economic 
activity in the study area. Because of the importance of ground water to the economy of the study area, a better understanding of the aquifer system is needed.

The Columbia Plateau regional aquifer-system analysis study was started in 1982 and completed in 1989. The study evaluates: effects of declining water levels due to development (about 20 feet per year); occurrence of sodium-enriched water, need of water for expanding irrigated land; and potential use of low-permeability zones in the deep basalts as a repository site for solidified high-level nuclear wastes near Richland, Washington. The study has completed 24 reports as listed below. As of May 1991, additional reports are still in preparation or in review.

1. Bauer, H.H., and Vaccaro, J.J., 1986, Model estimates of climatological variability on ground-water, in Climate and Water Management--a critical era: American Meteorological Society Conference, Asheville, North Carolina, August 4-7, 1986, Proceedings, p. 45-49.

2. 1987, Documentation of a deep percolation model for estimating ground-water recharge: U.S. Geological Survey Open-File Report 86-536, 180 p.

3. 1990, Estimates of ground-water recharge to the Columbia Plateau regional aquifer system, Washington, Oregon, and Idaho, for predevelopment and current land-use conditions: U.S. Geological Survey Water-Resources Investigations Report 88-4108, 37 p.

4. Bauer, H.H., Vaccaro, J.J., and Lane, R.C., 1985, Map showing ground-water levels in the Columbia River Basalt Group and overlying materials, spring 1983, southeastern Washington State: U.S. Geological Survey Water-Resources Investigations Report 84-4360, scale $1: 500,000,4$ sheets.

5. Cline, D.R., and Collins, C.A., in press, Ground-water pumpage from the Columbia Plateau, Washington and Oregon, 1945 to 1984: U.S. Geological Survey Water-Resources investigations Report 90-4085.

6. Cline, D.R., and Knadle, M.E., 1990, Ground-water pumpage from the Columbia Plateau regional aquifer system, Washington, 1984: U.S. Geological Survey Water-Resources Investigations Report 87-4135, $32 \mathrm{p}$.

7. Collins, C.A., 1987, Ground-water pumpage from the Columbia Plateau regional aquifer system, Oregon, 1984: U.S. Geological Survey Water-Resources Investigations Report 86-4211, $21 \mathrm{p}$.

8. Drost, B.W., and Whiteman, K.J., 1986, Surficial geology, structure and thickness of selected geohydrologic units in the Columbia Plateau, Washington: U.S. Geological Survey Water-Resources Investigations Report 86-4326, scale 1:500,000, 10 sheets.

9. Drost, B.W., Whiteman, K.J., and Gonthier, J.B., 1990, Geologic framework of the Columbia Plateau aquifer system, Washington, Oregon, and Idaho: U.S. Geological Survey Water-Resources Investigations Report 87-4238, scale 1:500,000, 10 sheets.

10. Gonthier, J.B., 1990, Geology, structure, and thickness of selected geohydrologic units in part of the Columbia Plateau, Oregon: U.S. Geological Survey Water-Resources Investigations Report 86-4001, scale 1:500,000, 6 sheets. 
11. Hansen, A.J., in press, Archiving of source code for the finite-difference flow model and the post-processors, and input and output files for the Columbia Plateau regional aquifer system, Washington, Oregon, and Idaho: U.S. Geological Survey Open-File Report 90-364.

12. Hearn, P.P., Steinkampf, W.C., Bortleson, G.C., and Drost, B.W., 1985, Geochemical controls on dissolved sodium in basalt aquifers of the Columbia Plateau, Washington: U.S. Geological Survey Water-Resources Investigations Report 84-4304, 38 p.

13. Lane, R.C., 1988a, Selected ground-water information for the Columbia Plateau regional aquifer system, Washington and Oregon, 1982-1985: Volume 1. Geohydrology: U.S. Geological Survey Open-File Report 88-182, 236 p.

14. 1988b, Selected ground-water information for the Columbia Plateau regional aquifer system, Washington and Oregon, 1982-1985: Volume 2. Water-levels: U.S. Geological Survey Open-File Report 88-183, 136 p.

15. Lane, R.C., and Whiteman, K.J., 1989, Ground-water levels, spring 1985, and groundwater level changes, spring 1983 to spring 1985, in three basalt units underlying the Columbia Plateau, Washington and Oregon: U.S. Geological Survey Water-Resources Investigations Report 88-4018, scale 1:500,000, 4 sheets.

16. Lindholm, G.F., and Vaccaro, J.J., 1988, Region 2, Columbia Lava Plateau, in Back, William, Rosenshein, J.S., and Seaber, P.R., eds., Hydrogeology: Boulder, Colorado, Geological Society of America, Geology of North America, v. O-2, p. 37-50.

17. Nelson, L.M., 1991, Surface-water resources for the Columbia Plateau, Washington, Oregon, and Idaho: U.S. Geological Survey Water-Resources Investigations Report 88-4105, scale $1: 500,000,4$ sheets.

18. Steinkampf, W.C., 1989, Water-quality characteristics of the Columbia Plateau regional aquifer system in parts of Washington, Oregon, and Idaho: U.S. Geological Survey WaterResources Investigations Report 87-4242, 37 p.

19. Steinkampf, W.C., Bortleson, G.C., and Packard, F.A., 1985 Controls on ground-water chemistry in the Horse Heaven Hills, south-central Washington: U.S. Geological Survey WaterResources Investigations Report 85-4048, 26 p.

20. Vaccaro, J.J., 1986a, Plan of study for the regional aquifer-system analysis, Columbia Plateau, Washington, northern Oregon, and northwestern Idaho: U.S. Geological Survey WaterResources Investigations Report 85-4151, 25 p.

21. 1986b, Columbia Plateau regional aquifer-system study, in Sun, R.J., ed., Regional Aquifer-System Analysis Program of the U.S. Geological Survey--Summary of projects, 1978-84: U.S. Geological Survey Circular 1002, p. 141-145.

22. Vaccaro, J.J., and Bauer, H.H., 1990, Archiving of deep percolation models, data files, and calculated recharge estimates for the Columbia Plateau regional aquifer system, Washington, Oregon, and Idaho: U.S. Geological Survey Open-File Report 88-186, 13 p.

23. Whiteman, K.J., 1986, Ground-water levels in three basalt geohydrologic units underlying the Columbia Plateau in Washington and Oregon, spring 1984: U.S. Geological Survey WaterResources Investigations Report 86-4046, scale 1:500,000, 4 sheets. 
24. Whiteman, K.J., Vaccaro, J.J., Gonthier, J.B., and Bauer, H.H., in press, Hydrogeologic framework and geochemistry of the Columbia Plateau regional aquifer system: U.S. Geological Survey Professional Paper 1413-B.

\section{Great Basin, Nevada and Utah}

The Great Basin regional aquifer-system analysis study covers an area of about 140,000 square miles in parts of Nevada, Utah, and adjacent states. The area is characterized by generally north-trending mountain ranges that range in width from 5 to 15 miles and rise 1,000 to 5,000 feet above the adjoining valleys. The widths of the valleys are about the same as widths of the adjacent mountain ranges. The valleys are typically elongated, and many extend more than 50 miles in a north or northeast direction.

The area has a complex geologic history that includes major episodes of sedimentation, igneous activity, orogenic deformation, and continental rifting. A major tectonic change occurred about 17 million years ago with the onset of extensional faulting, which has formed the major basins and ranges that characterize the topography. The Great Basin contains a regional aquifer system in a sense that most of its separate valley basins share common geologic and hydrologic characteristics. Currently, some 242 hydrographic areas are recognized within the study area; most include one or more structural basins and associated basin-fill aquifers. A special situation exists in eastern Nevada and western Utah, where permeable carbonate rocks underlying the basin-fill deposits form a complex ground-water flow system with the characteristics of both basin-fill and carbonate rock aquifers.

In recent years, much of the study area has been considered for use by the MX missile system; also, large coal-fired power plants are being constructed at several locations, and the potential for disposal of solidified high-level radioactive waste at Yucca Mountain, Nevada, is being studied. These activities will greatly affect the ground-water resources in much of the study area within the next several decades.

The Great Basin regional aquifer-system analysis study was started in 1980 and completed in 1988. The objectives of this study were to describe the aquifer systems in the Great Basin and, to the extent possible, to develop techniques that can be used for quantitative evaluation of the aquifer systems. This regional aquifer-system study provided a basis for evaluating the local and regional effects of future development. The approach was strongly influenced by the diverse nature of the ground-water flow systems and the large number of basins. A detailed appraisal of 242 individual areas was not feasible. Consequently, the approach taken was to study selected typical areas, identify key hydrologic processes, and then attempt to transfer the knowledge developed to areas of similar geohydrology. The study has completed 48 reports as listed below. Even though the project activity was completed in 1988, some additional reports are still in preparation or in review as of May 1991

1. Bedinger, M.S., Harrill, J.R., Langer, W.H., Thomas, J.M., and Mulvihill, D.A., 1985, Maps showing ground-water levels, springs, and depth to ground water, Basin and Range Province, Nevada: U.S. Geological Survey Water-Resources Investigations Report 83-4119-B, scale 1:500,000.

2. Bedinger, M.S., Harrill, J.R., and Thomas J.M., 1985, Maps showing ground-water units and withdrawal, Basin and Range Province, Nevada: U.S. Geological Survey Water Resources Investigations Report 83-4119-A, scale 1:500,000. 
3. Bunch, R.L., and Harrill, J.R., 1984, Compilation of selected hydrologic data from the MX missile-siting investigation, east-central Nevada and western Utah: U.S. Geological Survey OpenFile Report 84-702, 123 p.

4. Burbey, T.J., and Prudic, D.E., 1991, Conceptual evaluation of regional ground-water flow in the carbonate-rock province of the Great Basin, Nevada, Utah, and adjacent states: U.S. Geological Survey Professional Paper 1409-D, 84 p.

5. Campana, M.E., and Boone, R.L., 1986, Hydrologic monitoring of subsurface flow and ground-water recharge in a mountain watershed: American Water Resources Association Symposium on Cold Regions Hydrology, Fairbanks, Alaska, July 1986, Proceedings, p. 263-273.

6. Carlton, S.M., 1985, Fish Springs multibasin flow system, Nevada and Utah: University of Nevada, Reno, Master of Science Thesis, 103 p.

7. Carlton, S.M., and Thomas, J.M., 1987, Documentation for a digital computer model of the basin-fill aquifer in Smith Creek Valley, Lander County, Nevada: U.S. Department of Commerce National Technical Information Service, PB-87142899 (text) and PB-87142907 (magnetic tape), 6 p., 1 magnetic tape.

8. Carman, R.L., 1989, Data on evapotranspiration in phreatophyte areas, Smith Creek Valley and Carson Desert, west-central Nevada, 1983: U.S. Department of Commerce National Technical Information Service, PB-89167407 (magnetic tape).

9. in press, Measurement of evapotranspiration in phreatophyte areas, Smith Creek Valley and Carson Desert, west-central Nevada, 1983: U.S. Geological Survey Water-Resources Investigations Report 89-4118.

10. Dettinger, M.D., 1989, Reconnaissance estimates of natural recharge to desert basins in Nevada, U.S.A., by using chloride-balance calculations: Journal of Hydrology, v. 106, no. $1-2$, p. $55-78$.

11. Gates, J.S., 1984, Hydrogeology of northwestern Utah and adjacent parts of Idaho and Nevada: Utah Geological Association Publication 13, p. 239-248.

12. 1987, Ground water in the Great Basin, part of the Basin and Range Province, western Utah, in Cenozoic geology of western Utah--Sites for Precious Metal and Hydrocarbon Accumulations: Utah Geological Association Publication 16, p. 75-89.

13. Gates, J.S., and Bedinger, M.S., 1988, Ground-Water flow systems of western Utah, in McLean, J.S., and Johnson, A.I., eds., Regional Aquifer Systems of the United States, Aquifers of the Western Mountain Area: American Water Resources Association Monograph Series, no. 14, p. $37-55$.

14. Harrill, J.R., 1984, Great Basin aquifer systems, Nevada-Utah--an overview, in Water Today and Tomorrow: American Society of Civil Engineers Irrigation and Drainage Division Specialty Conference, Flagstaff, Arizona, 1984, Proceedings, p. 590-597.

15. 1986, Great Basin regional aquifer-system study, in Sun, R.J., ed., Regional AquiferSystem Analysis Program of the U.S. Geological Survey--summary of projects, 1978-84: U.S. Geological Survey Circular 1002, p. 146-151. 
16. Harrill, J.R., Gates, J.S., and Thomas, J.M., 1988, Major ground-water flow systems in the Great Basin region of Nevada, Utah, and adjacent states: U.S. Geological Survey Hydrologic Investigations Atlas HA-694-C, scale 1:100,000, 2 sheets.

17. Harrill, J.R., Gates, J.S., Thomas, J.M., and Mifflin, M.D., 1988, Ground-water flow systems in the Great Basin, in Back, William, Rosenshein, J.S., and Seaber, P.R., eds., Hydrogeology: Boulder, Colorado, Geological Society of America, Geology of North America, v. O-2, plate 3 , scale $1: 1,000,000$.

18. Harrill, J.R., and Preissler, A.M., in press, Ground-water flow and simulated response to several developmental scenarios in Stagecoach Valley--a small partly-drained basin in Lyon and Storey Counties, Nevada: U.S. Geological Survey Professional Paper 1409-H.

19. Harrill, J.R., Welch, A.H., and Preissler, A.M., 1984, Hydrogeologic controls on ground-water flow in Stagecoach Valley, Nevada, in Lintz, Joseph, Jr., ed., Western Geological Excursions: Reno, Nevada, University of Nevada, Mackay School of Mines, v. 3 , p. $117-120$.

20. Harrill, J.R., Welch, A.H., and Preissler, A.M., in press, Hydrogeochemical evidence for subsurface inflow to Stagecoach Valley, Lyon County, Nevada, in Subitzky, Seymour, ed., Water-Supply Paper 2340.

21. Harrill, J.R., Welch, A.H., Prudic, D.E., Thomas, J.M., Carman, R.L., Plume, R.W., Gates, J.S., and Mason, J.L., 1983, Aquifer systems in the Great Basin region of Nevada, Utah, and adjacent states--a study plan: U.S. Geological Survey Open-File Report 82-445, 49 p.

22. Mason, J.L., Atwood, John, and Buettner, Priscilla, 1985, Selected test well data from the MX missal system study, Tooele, Millard, Beaver, and Iron Counties, Utah: U.S. Geological Survey Open-File Report 85-347, 13 p.

23. Plume, R.W., 1989, Use of aeromagnetic data to define boundaries of a carbonate-rock aquifer in east-central Nevada, in Subitzky, Seymour, ed., Selected papers in the hydrologic sciences: U.S. Geological Survey Water-Supply Paper 2330, p. 1-10.

24. _ in press, Hydrogeologic framework of aquifer systems in the Great Basin region of Nevada, Utah, and adjacent states: U.S. Geological Survey Professional Paper 1409-B.

25. Plume, R.W., and Carlton, S.M., 1988, Hydrogeology of the Great Basin region of Nevada, Utah, and adjacent states: U.S. Geological Survey Hydrologic Investigations Atlas HA-694-A, scale $1: 100,000$.

26. Prudic, D.E., 1989, Documentation of a computer program to simulate stream-aquifer relations using a modular, finite-difference, ground-water flow model: U.S. Geological Survey Open-File Report 88-729, 113 p.

27. Robbins, S.L., Prudic, D.E., Schaefer, D.H., and Clutsom, F.G., 1985, Principal facts and density estimates for borehole gravity stations in three water wells located in Dixie and Paradise Valleys, Nevada: U.S. Geological Survey Open-File Report 85-426, 20 p.

28. Schaefer, D.H., 1988, Bouguer gravity anomaly maps of Paradise, Stagecoach, Dixie, Fairview, and Stingaree Valleys, northwestern Nevada: U.S. Geological Survey Geophysical Investigations Map GP-985, 1 over-size sheet. 
29. Schaefer, D.H., Duffrin, B.G., and Plume, R.W., 1985, Principal facts for gravity stations in Paradise and Stagecoach Valleys, Humboldt and Lyon Counties, Nevada: U.S. Geological Survey Open-File Report 85-694, 15 p.

30. Schaefer, D.H., Thomas, J.M., and Duffrin, B.G., 1984, Principal facts for gravity stations in Dixie, Fairview, and Stingaree Valleys, Churchill and Pershing Counties, Nevada: U.S. Geological Survey Open-File Report 84-586, 15 p.

31. Schulke, D.F., ed., 1987, Great Basin recharge studies: University of Nevada, Desert Research Institute Publication no. 41104, 127 p.

32. Thomas, J.M., Carlton, S.M., and Hines, L.B., 1989, Ground-water hydrology and simulated effects of development in Smith Creek Valley, a hydrologically closed basin in Lander County, Nevada: U.S. Geological Survey Professional Paper 1409-E, 57 p.

33. Thomas, J.M., Mason, J.L., and Crabtree, J.D., 1986, Ground-water levels in the Great Basin region of Nevada, Utah, and adjacent states: U.S. Geological Survey Hydrologic Investigations Atlas HA-694-B, scale 1:1,000,000, 2 sheets.

34. Thomas, J.M., Welch, A.H., and Preissler, A.M., 1989, Geochemical evolution of ground water in Smith Creek Valley--a hydrologically closed basin in central Nevada, U.S.A.: Applied Geochemistry, v. 4, p. 493-510.

35. Welch, A.H., and Williams, R.L., 1986a, Data on ground-water quality for the Millett 1 degree by 2 degree quadrangle, central Nevada: U.S. Geological Survey Open-File Report 85-648-A, scale 1:250,000.

36. 1986b, Data on ground-water quality for the Elko 1 degree by 2 degree quadrangle, eastern Nevada: U.S. Geological Survey Open-File Report 85-648-B, scale 1:250,000.

37. 1986c, Data on ground-water quality for the Ely 1 degree by 2 degree quadrangle, eastern Nevada: U.S. Geological Survey Open-File Report 85-648-C, scale 1:250,000.

38. 1986d, Data on ground-water quality for the Lund 1 degree by 2 degree quadrangle, eastern Nevada: U.S. Geological Survey Open-File Report 85-648-D, scale 1:250,000.

39. Welch, A.H., and Williams, R.P., 1987a, Data on ground-water quality for the McDermitt 1 degree by 2 degree quadrangle, northern Nevada: U.S. Geological Survey Open-File Report 85-648-E, scale 1:250,000.

40. 1987b, Data on ground-water quality for the Lovelock 1 degree by 2 degree quadrangle, western Nevada: U.S. Geological Survey Open-File Report 85-648-F, scale 1:250,000.

41. 1987c, Data on ground-water quality for the Winnemucca 1 degree by 2 degree quadrangle, central Nevada: U.S. Geological Survey Open-File Report 85-648-G, scale $1: 250,000$.

42. 1987d, Data on ground-water quality for the Reno 1 degree by 2 degree quadrangle, western Nevada: U.S. Geological Survey Open-File Report 85-648-H, scale 1:250,000.

43. 1987e, Data on ground-water quality for the Walker Lake 1 degree by 2 degree quadrangle, western Nevada and eastern California: U.S. Geological Survey Open-File Report 85-648-I, scale 1:250,000. 
44. 1987f, Data on ground-water quality for the Tonopah 1 degree by 2 degree quadrangle, central Nevada: U.S. Geological Survey Open-File Report 85-648-J, scale 1:250,000.

45. $1987 \mathrm{~g}$, Data on ground water quality for the western Nevada, part of the Goldfield 1 degree by 2 degree quadrangle: U.S. Geological Survey Open-File Report 85-648-K, scale $1: 250,000$.

46. 1987h, Data on ground-water quality for the Caliente 1 degree by 2 degree quadrangle, eastern Nevada: U.S. Geological Survey Open-File Report 85-648-L, scale 1:250,000.

47. 1987 , Data on ground-water quality for the western Nevada, part of the Death Valley 1 degree by 2 degree quadrangle: U.S. Geological Survey Open-File Report 85-648-M, scale $1: 250,000$.

48. $1987 \mathrm{j}$, Data on ground-water quality for the southern Nevada, part of the Kingman 1 degree by 2 degree quadrangle: U.S. Geological Survey Open-File Report 85-648-N, scale $1: 250,000$.

\section{Northeast Glacial Aquifers}

The Northeast Glacial-Aquifers study includes most of the glaciated parts of the northeastern United States and extends as far west as Ohio. Long Island, New York, and Cape Cod, Massachusetts, are excluded from the study because the ground-water hydrology of these areas has been extensively studied. The study area includes (1) mountainous areas of New Hampshire, Maine, Vermont, and New York; and (2) low-lying areas along the Great Lakes, major rivers, and the Coast.

The study area has been divided into three major types of geohydrologic terrains to represent the three types of aquifer systems that have similar characteristics. These divisions are based largely on the geology of glacial deposits and on physiography. Much of the study area and most of the productive glacial aquifers are in "type A" terrains, where aquifers were formed largely in valleys that drained away from glacial ice. Glacial aquifers in "type B" terrains were deposited in large glacial lakes or marine waters, and those in "type C" terrains were formed in deep valleys that drained toward glacial ice.

The Northeast Glacial-Aquifers study was started in 1981 and completed in 1989. The purpose of the study was to investigate the extent, productivity, and quality of water of the sand and gravel aquifers that were formed during advances and retreats of the continental glaciers in the northeastern United States. Although the Northeast glacial sand-and-gravel aquifers consist of many geographically independent systems, they share many geologic, hydrologic, and geochemical characteristics through their common depositional origins and physiographic settings. This study documented the local variations in magnitude and distribution of hydraulic properties of the aquifers through evaluation of the response of the aquifers to pumping and to seasonal stresses. The study has completed 27 reports as listed below. As of May 1991, additional reports are still under preparation or in review.

1. Breen, K.J., 1988, Geochemistry of the stratified-drift aquifer in Killbuck Creek Valley west of Wooster, Ohio, in Randall, A.D., and Johnson, A.I., eds., Regional Aquifer Systems of the United States, Northeast Glacial Aquifers: American Water Resources Association Monograph Series, no. 11 , p. 105-131. 
2. Coen, A.W. III, 1990, Ground-water levels, flow, and specific conductance in unconsolidated aquifers near Lake Erie, Cleveland to Conneaut, Ohio, September 1984: U.S. Geological Survey Water-Resources Investigations Report 89-4202, 22 p.

3. Dysart, J.E., 1988, Use of Oxygen-18 and Deuterium mass-balance analysis to evaluate induced recharge to stratified-drift aquifers, in Randall, A.D., and Johnson, A.I., eds., Regional Aquifer Systems of the United States, Northeast Glacial Aquifers: American Water Resources Association Monograph Series, no. 11, p. 133-154.

4. Haeni, F.P., 1986, The use of electromagnetic methods to delineate vertical and lateral lithologic changes in glacial aquifers: National Water Well Association Conference on Surface and Borehole Geophysical Methods and Ground Water Instrumentation, Denver, Colorado, October 15-17, 1986, Proceedings, p. 259-282.

5. 1988, Evaluation of the continuous seismic-reflection methods for determining the thickness and lithology of stratified drift in the glaciated northeast, in Randall, A.D., and Johnson, A.I., eds., Regional Aquifer Systems of the United States, Northeast Glacial Aquifers: American Water Resources Association Monograph Series, no. 11, p. 63-82.

6. _ in press, Application of surface-geophysical methods to investigations of sand and gravel aquifers in the glaciated northeastern United States: U.S. Geological Survey Professional Paper 1415-E.

7. Haeni, F.P., and Melvin, R.L., 1984, High resolution continuous seismic reflection study of a stratified-drift deposit in Connecticut: National Water Well Association Conference on Surface and Borehole Geophysical Methods in Ground Water Investigations, San Antonio, Texas, February 7-9, 1984, Proceedings, p. 237-256.

8. Lapham, W.W., 1989, Use of temperature profiles beneath streams to determine rates of vertical ground-water flow and vertical hydraulic conductivity: U.S. Geological Survey WaterSupply Paper 2337, 35 p.

9. Lyford, F.P., 1986, Northeast glacial regional aquifer-system study, in Sun, R.J., ed., Regional Aquifer-System Analysis Program of the U.S. Geological Survey--summary of projects, 1978-84: U.S. Geological Survey Circular 1002, p. 162-167.

10. Lyford, F.P., and Cohen, A.J., 1988, Estimation of water available for recharge to sand and gravel aquifers in the glaciated Northeastern United States, in Randall, A.D., and Johnson, A.I., eds., Regional Aquifer Systems of the United States, Northeast Glacial Aquifers: American Water Resources Association Monograph Series, no. 11, p. 37-62.

11. Lyford, F.P., Dysart, J.E., Randall, A.D., and Kontis, A.L., 1984, Glacial aquifer systems in the Northeastern United States--a study plan: U.S.Geological Survey Open-File Report 83-928, 33 p.

12. Mazzaferro, D.L., 1986, Ground-water yields for selected stratified-drift areas in Connecticut: Connecticut State Department of Environmental Protection Natural Resources Atlas Series, scale 1:125:000.

13. Miller, T.S., in press, Glacial geology and the origin and distribution of aquifers at the valley heads moraine in the Virgil Creek and Dryden Lake-Harford Valleys, Tompkins and Cortland Counties, New York: U.S. Geological Survey Water-Resources Investigations Report 90-4168. 
14. Morrissey, D.J., Haeni, F.P., and Tepper, D.H., 1985, Continuous seismic-reflection profiling of a glacial-drift deposit on the Saco River, Maine and New Hampshire: National Water Well Association Annual Eastern Regional Ground Water Conference, 2nd, Portland, Maine, July 16-18, 1985, Proceedings, p. 277-296.

15. Morrissey, D.J., Randall, A.D., and Williams, J.H., 1988, Upland runoff as a major source of recharge to stratified drift in the glaciated Northeast, in Randall, A.D., and Johnson, A.I., eds., Regional Aquifer Systems of the United States, Northeast Glacial Aquifers: American Water Resources Association Monograph Series, no. 11, p. 17-36.

16. Randall, A.D., 1986, Ice readvance in Fivemile Creek Valley and its effect on postglacial streamflow: New York State Geological Association Annual Meeting, 58th, Ithaca, New York, October 10-12, 1986, Guidebook, p. 239-260.

17. Randall, A.D., and Johnson, A.I., 1988, The Northeast glacial aquifers RASA project--an overview of results through 1987, in Randall, A.D., and Johnson, A.I., eds., Regional Aquifer Systems of the United States, Northeast Glacial Aquifers: American Water Resources Association Monograph Series, no. 11, p. 1-16.

18. Randall, A.D., Francis, R.M., Frimpter, M.H., and Emery, J.M., 1988, Region 19, Northeastern Appalachians, in Back, William, Rosenshein, J.S., and Seaber, P.R., eds., Hydrogeology: Boulder, Colorado, Geological Society of America, Geology of North America, v. O-2, p. 177-187.

19.. Randall, A.D., Snavely, D.S., Holecek, T.S., and Waller, R.M., 1988, Alternative sources of large seasonal ground-water supplies in the headwaters of the Susquehanna River Basin, New York: U.S. Geological Survey Water-Resources Investigations Report 85-4127, 121 p.

20. Reynolds, R.J., and Williams, J.H., 1988, Continuous seismic-reflection profiling of glacial drift along the Susquehanna, Chemung, and Chenango Rivers, south-central New York and northcentral Pennsylvania, in Randall, A.D., and Johnson, A.I., eds., Regional Aquifer Systems of the United States, Northeast Glacial Aquifers: American Water Resources Association Monograph Series, no. 11, p. 83-104.

21. Rogers, R.J., 1987, Geochemical evolution of groundwater in stratified-drift and arkosic bedrock aquifers in north-central Connecticut: Water Resources Research, v. 23, no. 8 , p. 1531-1545.

22. 1989, Geochemical comparison of ground water in areas of New England, New York, and Pennsylvania: Ground Water, v. 27, no. 5, p. 690-712.

23. Tepper, D.H., Morrissey, D.J., Johnson, C.D., and Malony, T.J., 1990, Hydrogeology, water quality and effects of increased municipal pumpage of the Saco River Valley glacial aquifer, Bartlett, New Hampshire to Fryeburg, Maine: U.S. Geological Survey Water-Resources Investigations Report 88-4179, 113 p.

24. Williams, J.H., in press, Tributary-stream infiltration in Marsh Creek Valley, north-central Pennsylvania: U.S. Geological Survey Water-Resources Investigations Report 90-4052.

25. Wiltshire, D.A., Lyford, F.P., and Cohen, A.J., 1986, Bibliography on ground water in glacial-aquifer systems in the Northeastern United States: U.S. Geological Survey Circular 972, 26 p. 
26. Yager, R.M., 1986, Simulation of ground-water flow and infiltration from the Susquehanna River to a shallow aquifer at Kirkwood and Conklin, Broome County, New York: U.S. Geological Survey Water-Resources Investigations Report 86-4123, 70 p.

27. Yager, R.M., in press, Estimation of hydraulic conductivity in a streambed-aquifer system, Susquehanna River in Broome county, New York: U.S. Geological Survey Water-Resources Investigations Report 88-4026.

\section{Oahu, Hawaii}

The Island of Oahu has a land area of 604 square miles and was formed through building and subsequent coalescence of two shield volcanoes, the Waianae and Koolau Volcanoes. The Waianae Volcano forms the western part of Oahu, and the Koolau Volcano forms the eastern part. A long period of quiescence followed the initial mountain building. During the quiescence, both volcanoes were deeply eroded. The Waianae Volcano became dormant first, and the westward dipping flows of the Koolau Volcano overlapped the eroded surface of the Waianae Volcano in the central part of the island. Subsidence of Oahu submerged permeable lava flows and placed them in hydraulic contact with the surrounding ocean water. Shifts in sea level and erosion allowed deposits of marine and terrestrial sediments to accumulate behind barrier reefs, forming coastal plains in some areas.

Due to complexity of volcanic rocks and island environment, unique hydrologic terms were developed in Hawaii. A body of ground water floating on and in hydrodynamic equilibrium with saltwater is termed "basal ground water," or "basal water body," in Hawaii. Ground water stored in lavas between low permeability intrusion dikes is termed "dike impounded water body." In areas where water levels are much higher than the expected water table of a basal water body but geological reasons for the occurrence is not known (water is either impeded by low permeability dikes, ash beds, or other low permeability rocks), the ground water is termed as "high-level water body." Water in the dike-impounded or high-level water body area eventually seeps through or overflows the low permeability dikes or barriers, and discharges into adjacent basal water bodies, or leaks to streams in adjacent valleys. Ground water is also perched in places. The perched water is unconfined and is separated from an underlying basal water body by an unsaturated layer of ash beds or low permeability materials. On the basis of this concept, the Oahu aquifer system is grouped into 10 aquifers. From west to east, they are: (1) Waianae basal water body; (2) Waianae dike impounded water body ; (3) Mokuleia basal water body; (4) Kawailoa basal water body; (5) Waialua basal water body; 6) Schofield high-level water body; (7) Honolulu-Pearl Harbor basal water body; (8) southeast basal water body; (9) Koolau dike impounded water body and; (10) northeast basal water body.

Several recent studies have concluded that the ground-water resource of the Island of Oahu will be near maximum development by the year 2000 . Estimates of long-term potential of groundwater development of the Oahu aquifer system range between 480 and 635 million gallons per day. In the 1980 s, ground-water withdrawal rate was about 400 million gallons per day, which is about 85 percent of the island's total water use.

The Oahu regional aquifer-system analysis study was started in 1982 and completed in 1988 to evaluate the impact of the potential development of the aquifer system. Computer models were used to simulate ground-water flow to evaluate effects of ground-water development on water levels as well as on the movement of the freshwater-saltwater interface. As of May 1991, eight reports have been completed as listed below. Additional reports are still in preparation or in review. 
1. Ewart, C.J., 1986, Oahu Island regional aquifer-system study, in Sun, R.J., ed., Regional Aquifer-System Analysis Program of the U.S. Geological Survey--summary of projects, 1978-84: U.S. Geological Survey Circular 1002, p. 195-204.

2. Eyre, P.R., 1985, Simulation of ground-water flow in southeastern Oahu, Hawaii: Ground Water, v. 23, no. 3, p. 325-330.

3. Eyre, P.R., Ewart, C.J., and Shade, Patricia, 1985, Hydrology of the leeward aquifer, southeast Oahu, Hawaii: U.S. Geological Survey Water-Resources Investigations Report $85-4270,75$ p.

4. Hunt, C.D., Ewart, C.J., and Voss, C.I., Region 27, Hawaiian Islands, in Back, William, Rosenshein, J.S., Seaber, P.R., eds., Hydrogeology: Boulder Colorado, Geological Survey of America, Geology of North America, v. O-2, p. 263-270.

5. Miyamoto, S.E., Miyaji, C.E., and Fukuda, L.L., 1986, Summary of available ground-water data for the Island of Oahu, Hawaii: U.S. Geological Survey Open-File Report 86-233, 216 p.

6. Shade, P.J., in press, Distribution of ground-water recharge, Oahu, Hawaii: U.S. Geological Survey Hydrologic Investigations Atlas HA-725, 1 over-size sheet.

7. Souza, W.R., and Voss, C.I., 1986, Modeling a regional aquifer containing a narrow transition between freshwater and saltwater using a solute transport simulation, Part II--Analysis of a coastal aquifer system: Delft University of Technology Salt Water Intrusion Meeting, 9th, Delft, Netherlands, May 12-16, 1986, Proceedings, p. 457-473.

8. Voss, C.I., and Souza, W.R., 1986, Modeling a regional aquifer containing a narrow transition between freshwater and saltwater using a solute transport simulation, Part I--Theory and methods: Delft University of Technology Salt Water Intrusion Meeting, 9th, Delft, Netherlands, May 12-16, 1986, Proceedings, p. 493-514.

\section{San Juan Basin, Arizona, Colorado, New Mexico, and Utah}

The San Juan structural basin, in New Mexico, Colorado, Arizona, and Utah, has an area of about 21,600 square miles. The regional aquifer-system analysis study of the San Juan Basin includes rocks of Triassic or younger age which underlie about 19,400 square miles of the structural basin. Annual precipitation in the mountainous areas along the northern and eastern margins of the basin ranges from 20 to 30 inches, whereas the lower-altitude central part of the basin receives 10 or fewer inches per year. Altitudes in the study area range from about 4,500 feet in the northwest to about 11,000 feet in the southeast.

The San Juan Basin is a northwest-trending asymmetric structural depression of Laramide (late Cretaceous through early Tertiary) age at the eastern edge of the Colorado Plateau. The basin is about 140 miles wide and about 200 miles long. The San Juan structural basin contains a thick sequence (more than 14,000 feet) of sedimentary rocks ranging in age from Cambrian through Tertiary. These sedimentary rocks dip from the basin margins toward the trough-like structural center of the basin. The older sedimentary rocks crop out around the basin margins and are successively overlain by younger rocks toward the structural center of the basin. Tertiary volcanic rocks and various Quaternary deposits also are present in the basin.

The aquifers studied are in rocks of Triassic through Tertiary age. The aquifer system has been divided into eight aquifers ranging from single geologic formations to the entire Tertiary 
section. The most important aquifers are composed of the Morrison Formation, Gallup Sandstone, and Dakota Sandstone.

The economy of the study area is supported by exploration and development of petroleum, coal, and uranium resources; urban enterprise; farming and ranching; tourism; and recreation. The population of the basin in the 1980s was about 190,000. Ground water is an important resource in much of the San Juan Basin because surface water has been fully appropriated or is not available. Historically, the main uses of ground water were for municipal, domestic, and stock purposes; however, industrial use has increased significantly since the late 1970's because of increased uranium mining in the Morrison Formation. Ground-water levels have declined in several areas where dewatering of the Morrison Formation was necessary for mining operations. Competition of water use has been great among electric-power companies, municipalities, Indian communities, and mining companies for rights to use the limited ground-water resource in the basin.

The San Juan Basin regional aquifer-system analysis study was started in 1984 and completed in 1990. The principal objectives were to: (1) define and evaluate the aquifer system in the San Juan Basin, (2) assess the effects of past, present, and potential ground-water use on aquifers and streams, and (3) determine the availability and quality of ground water in the basin. The study has completed 14 reports as listed below. As of May 1991, additional reports are still in preparation or in review.

1. Craigg, S.D., Dam, W.L., Kernodle, J.M., and Levings, G.W., 1989, Hydrogeology of the Dakota Sandstone in the San Juan structural basin, New Mexico, Colorado, Arizona, and Utah: U.S. Geological Survey Hydrologic Investigations Atlas HA-720-I, scale 1:1,000,000 and $1: 2,000,000,2$ sheets.

2. Craigg, S.D., Dam, W.L., Kernodle, J.M., Thorn, C.R., and Levings, G.W., 1990, Hydrogeology of the Point Lookout Sandstone in the San Juan structural basin, New Mexico, Colorado, Arizona, and Utah: U.S. Geological Survey Hydrologic Investigations Atlas HA-720-G, scale 1:1,000,000 and 1:2,000,000, 2 sheets.

3. Dam, W.L., 1988, Methods and preliminary results of geochemical sampling, San Juan Basin, New Mexico, Colorado, Arizona, and Utah, in McLean, J.S., and Johnson, A.I., eds., Regional Aquifer Systems of the United States, Aquifers of the Western Mountain Area: American Water Resources Association Monograph Series, no. 14, p. 203-217.

4. Dam, W.L., Kernodle, J.M., Levings, G.W., and Craigg, S.D., 1990, Hydrogeology of the Morrison Formation in the San Juan structural basin, New Mexico, Colorado, Arizona, and Utah: U.S. Geological Survey Hydrologic Investigations Atlas HA-720-J, scale 1:1,000,000 and $1: 2,000,000,2$ sheets.

5. Dam, W.L., Kernodle, J.M., Thorn, C.R., Levings, G.W., and Craigg, S.D., 1990, Hydrogeology of the Pictured Cliffs Sandstone in the San Juan structural basin, New Mexico, Colorado, Arizona, and Utah: U.S. Geological Survey Hydrologic Investigations Atlas HA-720-D, scale 1:1,000,000 and 1:2,000,000, 2 sheets.

6. Kernodle, J.M., and Craigg, S.D., in press, Using a geographic information system to assist in a regional aquifer-system analysis: U.S. Geological Survey Yearbook, Fiscal Year 1991.

7. Kernodle, J.M., and Philip, R.D., 1988, Using a geographic information system to develop a ground-water flow model, in McLean, J.S., and Johnson, A.I., eds., Regional Aquifer Systems 
of the United States, Aquifers of the Western Mountain Area: American Water Resources Association Monograph Series, no. 14, p. 191-202.

8. Kernodle, J.M., Levings, G.W., Craigg, S.D., and Dam, W.L., 1990, Hydrogeology of the Gallup Sandstone in the San Juan structural basin, New Mexico, Colorado, Arizona, and Utah: U.S. Geological Survey Hydrologic Investigations Atlas HA-720-H, scale 1:1,000,000 and $1: 2,000,000,2$ sheets.

9. Kernodle, J.M., Thorn, C.R., Levings, G.W., Craigg, S.D., and Dam, W.L., 1990, Hydrogeology of the Kirtland Shale and Fruitland Formation in the San Juan structural basin, New Mexico, Colorado, Arizona, and Utah: U.S. Geological Survey Hydrologic Investigations Atlas HA-720-C, scale 1:1,000,000 and 1:2,000,000, 2 sheets.

10. Levings, G.W., Craigg, S.D., Dam, W.L., Kernodle, J.M., and Thorn, C.R., 1990a, Hydrogeology of the San Jose, Nacimiento, and Animas Formations in the San Juan structural basin, New Mexico, Colorado, Arizona, and Utah: U.S. Geological Survey Hydrologic Investigations Atlas HA-720-A, scale 1:1,000,000 and 1:2,000,000, 2 sheets.

11. 1990b, Hydrogeology of the Menefee Formation in the San Juan structural basin, New Mexico, Colorado, Arizona, and Utah: U.S. Geological Survey Hydrologic Investigations Atlas HA-720-F, scale 1:1,000,000 and 1:2,000,000, 2 sheets.

12. Thorn, C.R., Levings, G.W., Craigg, S.D., Dam, W.L., and Kernodle, J.M., 1990a, Hydrogeology of the Ojo Alamo Sandstone in the San Juan structural basin, New Mexico, Colorado, Arizona, and Utah: U.S. Geological Survey Hydrologic Investigations Atlas HA-720-B, scale 1:1,000,000 and 1:2,000,000, 2 sheets.

13. 1990b, Hydrogeology of the Cliff House Sandstone in the San Juan structural basin, New Mexico, Colorado, Arizona, and Utah: U.S. Geological Survey Hydrologic Investigations Atlas HA-720-E, scale 1:1,000,000 and 1:2,000,000, 2 sheets.

14. Welder, G.E., 1986, Plan of study for the regional aquifer-system analysis of the San Juan structural basin, New Mexico, Colorado, Arizona, and Utah: U.S. Geological Survey WaterResources Investigations Report 85-4294, 23 p.

\section{Snake River Plain, Idaho}

The Snake River Plain covers an area of about 15,600 square miles that extends across southern Idaho into eastern Oregon. The Snake River descends 2,930 feet along its 502-mile course through the study area. The surface of the plain decreases in altitude from about 6,000 feet above sea level in the northeast to 2,100 feet in the west. Average annual precipitation on much of the plain is less than 10 inches, one-third to one-half of which falls during the growing season from April through September. Most water available to the plain originates as snow on surrounding mountains, which are as much as 12,000 feet above sea level. Annual precipitation in the mountains is as much as 60 inches. For study purposes, the plain was divided into eastern and western parts on the basis of geology and hydrology.

The eastern plain is basically a downwarp. Most of the fill consists of Quaternary basalt. Near the margins, unconsolidated sedimentary rocks overlie and are intercalated with the basalt. The tops of basalt flows are typically broken and have large values of hydraulic conductivity. Consequently, thick sections of basalt, which include many separate flows, store and yield large quantities of water. In places, the basalt aquifer may be several thousand feet thick; however, the 
upper 200 to 500 feet are thought to be the most permeable. In much of the eastern plain, the regional aquifer system is unconfined. About two-thirds of the ground water discharged from the eastern plain is through a series of springs that flow to the Snake River, including 11 of 65 springs in the United States that discharge an average of more than 100 cubic feet per second.

The western plain is a graben bounded by well-defined high-angle faults. Tertiary and Quaternary sedimentary rocks of variable thickness are the predominant fill material. In the Boise River valley, most water is obtained from unconfined alluvial sand and gravel. Elsewhere, the deposits are predominantly fine grained but contain some sand and gravel. The fine-grained aquifers are largely confined. Ground-water discharge to the Snake River in the western plain is small relative to that in the eastern plain.

The economy of southern Idaho is based largely on agriculture, which is dependent on an adequate supply of good-quality water for irrigation. In the past, most water for irrigation was obtained from the Snake River. By the early 1950 's, ground water was also a major source of water for irrigation.

The Snake River Plain regional aquifer-system analysis study was started in 1979. Its purpose was to provide a better understanding of the hydrologic system in the Snake River plain so that future demands for water could be effectively managed. The study was conducted in two phases. During phase I (completed in 1984), computer models of the eastern and western parts of the Snake River Plain were developed and used to simulate long-term regional hydrologic changes. During phase II (completed in 1990), site specific studies were conducted for areas where detailed information was needed. As of May 1990, the study has completed 35 reports as listed below, additional reports are still in review or in preparation.

1. Bassick, M.D., 1985, Ground-water levels, 1980, Snake River Plain, Idaho and eastern Oregon: U.S. Geological Survey Open-File Report 85-330, 77 p.

2. 1986, Compilation of references on geology and hydrology of the Snake River drainage basin above Weiser, Idaho: U.S. Geological Survey Open-File Report 86-245, 134 p.

3. Bigelow, B.B., Goodell, S.A., and Newton, G.D., 1987, Water withdrawn for irrigation in 1980 on the Snake River Plain, Idaho and eastern Oregon: U.S. Geological Survey Hydrologic Investigations Atlas HA-690, scale 1:1,000,000, 2 sheets.

4. Bisdorf, R.J., 1983, Schlumberger soundings on the Snake River Plain near Nampa, Idaho: U.S. Geological Survey Open-File Report 83-412, 56 p.

5. 1987, Schlumberger sounding results near Twin Falls, Idaho: U.S. Geological Survey Open-File Report 87-166, 90 p.

6. Covington, H.R., and Weaver, J.N., 1990a, Geologic map and profiles of the north wall of the Snake River canyon, Bliss, Hagerman, and Tuttle quadrangles, Idaho: U.s. Geological Survey Miscellaneous Investigations Map I-1947-A, scale 1:24,000.

7. 1990b, Geologic map and profiles of the north wall of the Snake River canyon, Pasadena Valley and Ticeska quadrangles, Idaho: U.S. Geological Survey Miscellaneous Investigations Map I-1947-B, scale 1:24,000. 
8. 1990c, Geologic map and profiles of the north wall of the Snake River canyon, Jerome, Filer, Twin Falls, and Kimberly quadrangles, Idaho: U.S. Geological Survey Miscellaneous Investigations Map I-1947-D, scale 1:24,000.

9. 1990d, Geologic map and profiles of the north wall of the Snake River canyon, Eden, Murtaugh, Milner Butte, and Milner quadrangles, Idaho: U.S. Geological Survey Miscellaneous Investigations Map I-1947-E, scale 1:24,000.

10. 1991, Geologic map and profiles of the north wall of the Snake River canyon, Thousand Springs and Niagara Springs quadrangles, Idaho: U.S. Geological Survey Miscellaneous Investigations Map I-1947-C, scale 1:24,000.

11. Covington, H.R., Whitehead, R.L., and Weaver, J.N., 1985, Ancestral canyons of the Snake River; geology and geohydrology of canyon-fill deposits in the Thousand Springs area, south-central Snake River Plain, Idaho: Geological Society of America Rocky Mountain Section Annual Meeting, 38th, Boise, Idaho, 1985, Composite Field Guide, Trip 7, 30 p.

12. Garabedian, S.P., 1986, Application of a parameter-estimation technique to modeling the regional aquifer underlying the eastern Snake River Plain, Idaho: U.S. Geological Survey Water-Supply Paper 2278, 60 p.

13. in press, Hydrology and digital simulation of the regional aquifer system, eastern Snake River Plain, Idaho: U.S. Geological Survey Professional Paper 1408-F.

14. Goodell, S.A., 1988, Water use on the Snake River Plain, Idaho and eastern Oregon: U.S. Geological Survey Professional Paper 1408-E, 51 p.

15. Johnson, G.S., Brockway, C.E., and Luttrell, S.P., 1984, Application of a numerical ground-water flow model to the Mud Lake area in southeastern Idaho: Moscow, Idaho, University of Idaho Technical Completion Report, $60 \mathrm{p}$.

16. Kjelstrom, L.C., 1986, Flow characteristics of the Snake River and water budget for the Snake River Plain, Idaho and eastern Oregon: U.S. Geological Survey Hydrologic Investigations Atlas HA-680, scale 1:1,000,000, 2 sheets.

17. in press, Streamflow gains and losses in the Snake River and ground-water budgets for the Snake River Plain, Idaho and eastern Oregon: U.S. Geological Survey Professional Paper 1408-C.

18. Lindholm, G.F., 1981, Plan of study for the regional aquifer-system analysis of the Snake River Plain, Idaho and eastern Oregon: U.S. Geological Survey Open-File Report 81-689, 21 p.

19. 1986a, Snake River Plain regional aquifer-system study, in Sun, R.J., ed., Regional Aquifer-System Analysis Program of the U.S. Geological Survey--summary of projects, 1978-84: U.S. Geological Survey Circular 1002, p. 88-106.

20. 1986b, Snake River Plain regional aquifer system, Phase II study, in Sun, R.J., ed., Regional Aquifer-System Analysis Program of the U.S. Geological Survey--summary of projects, 1978-84: U.S. Geological Survey Circular 1002, p. 259-261.

21. 1988, Snake River Plain regional aquifer system study, in McLean, J.S., and Johnston, A.I., eds., Regional Aquifer System of the United States, Aquifers of the Western Mountain Area: American Water Resources Association Monograph Series, no. 14, p. 15-36. 
22. in press, Summary of the Snake River regional aquifer-system analysis in Idaho and eastern Oregon: U.S. Geological Survey Professional Paper 1408-A.

23. Lindholm, G.F., Garabedian, S.P., Newton, G.D., and Whitehead, R.L., 1983, Configuration of the water table, March 1980, in the Snake River Plain regional aquifer system, Idaho and eastern Oregon: U.S. Geological Survey Open-File Report 82-1022, scale 1:500,000.

24. 1988 , Configuration of the water table and depth to water, spring 1980, water-level fluctuations, and water movement in the Snake River Plain regional aquifer system, Idaho and eastern Oregon: U.S. Geological Survey Hydrologic Investigations Atlas HA-703, scale $1: 500,000$.

25. Lindholm, G.F., and Goodell, S.A., 1986, Irrigated acreage and other land uses on the Snake River Plain, Idaho and eastern Oregon: U.S. Geological Survey Hydrologic Investigations Atlas HA-691, scale 1:500,000.

26. Low, W.H., 1987, Solute distribution in ground and surface water in the Snake River Basin, Idaho and eastern Oregon: U.S. Geological Survey Hydrologic Investigations Atlas HA-696, scale $1: 1,000,000,2$ sheets.

27. Newton, G.D., 1985, Computer programs for common map projections: U.S. Geological Survey Bulletin 1642, 33 p.

28. in press, Geohydrology of the regional aquifer system, western Snake River Plain, southwestern Idaho: U.S. Geological Survey Professional Paper 1408-G.

29. Whitehead, R.L., 1986a, Compilation of selected geophysical references for the Snake River Plain, Idaho and eastern Oregon: U.S. Geological Survey Geophysical Investigations Map GP-969, scale 1:1,000,000.

30. 1986b, Geohydrologic framework of the Snake River Plain, Idaho and eastern Oregon: U.S. Geological Survey Hydrologic Investigations Atlas HA-681, scale 1:1,000,000, 3 sheets.

31. in press, Geohydrologic framework of the Snake River Plain regional aquifer system, Idaho and eastern Oregon: U.S. Geological Survey Professional Paper 1408-B.

32. Whitehead, R.L., and Covington, H.R., 1987, Thousand Springs area near Hagerman, Idaho: Geological Society of America Rocky Mountain Section Centennial Field Guide, p. 31-34.

33. Whitehead, R.L., and Lindholm, G.F., 1984, Results of geohydrologic test drilling in the eastern Snake River Plain, Gooding County, Idaho: U.S. Geological Survey Water-Resources Investigations Report 84-4294, 30 p.

34. Wood, W.W., and Low, W.H., 1986, Aqueous geochemistry and diagenesis in the eastern Snake River Plain aquifer system, Idaho: Geological Society of America Bulletin, v. 97, no. 12, p. $1456-1466$.

35. 1988, Solute geochemistry of the Snake River Plain regional aquifer system, Idaho and eastern Oregon: U.S. Geological Survey Professional Paper 1408-D, 79 p. 


\section{Southwest Alluvial Basins}

Many alluvial basins exist in the southwestern United States. Some of these basins were selected for study under the RASA Program to understand the occurrence, movement, and quality of ground water in basin aquifer systems. The results of the study indicate that certain hydrologic and geologic information can be transferred to other basin aquifers. The Southwest Alluvial Basins regional aquifer-system analysis study was started in 1978 and completed in 1990. Geographically, the study was divided into two parts; one in parts of Colorado, New Mexico, and Texas, and the other in southern and central Arizona and parts of adjacent states.

The study in parts of Colorado, New Mexico, and Texas covers a total area of 70,000 square miles, and was completed in 1985. The basins are bounded on the north, east, and west mainly by Precambrian crystalline rocks, Paleozoic and Mesozoic sedimentary rocks, and Tertiary volcanic rocks. The southern boundary of the study area is not defined by structural or hydrologic boundaries but was arbitrarily placed at the Mexico-United States International Boundary.

Alluvial sediments in the basins were derived from surrounding highlands and mountains. The alluvial sediments are composed of flood-plain deposits and sediments of the Tertiary and Quaternary Santa Fe Group. The Santa Fe Group consists of unconsolidated to moderately consolidated lenticular deposits of gravel, sand, and clay interbedded in some places with volcanics.

Precipitation in the uplifted mountainous blocks east and west of the basins is the source of the surface water which eventually recharges the aquifers near the base of the mountains where infiltration rates are high. The other source of recharge is seepage from the Rio Grande. Most municipal and industrial wells in the study area are completed in the Santa Fe Group.

For this part of the Southwest Alluvial Basins regional-aquifer system analysis study, computer models of ground-water flow in four basins were developed and 30 reports were published as listed below.

1. Anderholm, S.K., 1983, Hydrogeology of the Socorro and La Jencia Basins, Socorro County, New Mexico: New Mexico Geological Society Guidebook, Field Conference, 34th, Socorro Region II, p. 303-310.

2. 1985, Clay-size fraction and powdered whole-rock x-ray analyses of alluvial basin deposits in central and southern New Mexico: U.S. Geological Survey Open-File Report 85-173, 18 p.

3. 1987, Hydrogeology of the Socorro and La Jencia Basins, Socorro County, New Mexico: U.S. Geological Survey Water-Resources Investigations Report 84-4342, 62 p.

4. 1988, Ground-water geochemistry of the Albuquerque-Belen Basin, central New Mexico: U.S. Geological Survey Water-Resources Investigations Report 86-4094, 110 p.

5. Birch, F.S., 1980a, Geophysical evaluation of basin hydrologic characteristics in the central Rio Grande Rift, part 1, Gravity models of the Albuquerque-Belen Basin: University of New Mexico contract no. $1408000117879,30 \mathrm{p}$.

6. 1980b, Three dimensional gravity modeling of basin hydrologic parameters in New Mexico: University of New Mexico contract no. 1408000117899,26 p. 

1982, Gravity models of the Albuquerque Basin, Rio Grande Rift, New Mexico: Geophysics, v. 47, no. 8, August 1982, p. 1182-1197.

8. Crouch, T.M., 1980, Potentiometric surface, 1980, and water-level changes, 1969-80, in the unconfined valley-fill aquifers of the San Luis Basin, Colorado and New Mexico: U.S. Geological Survey Hydrologic Investigations Atlas HA-683, scale 1:250,000, 2 sheets.

9. Frenzel, P.F., and Kaehler, C.A., 1990, Geohydrology and simulation of ground-water flow in the Mesilla Basin, Dona Ana County, New Mexico and El Paso County, Texas, with a section on water quality and geochemistry by Anderholm, Scott: U.S. Geological Survey, Open-File Report 88-305, 179 p, pending publication as Professional Paper 1407-C.

10. Hearne, G.A., 1983, Supplement to the New Mexico three dimensional model (supplement to U.S. Geological Survey Open-File Report 80-421): U.S. Geological Survey Open-File Report $82-857,90$ p.

11. Hearne, G.A., and Dewey, J.D., 1988, Hydrologic analysis of the Rio Grande Basin north of Embudo, New Mexico; Colorado and New Mexico: U.S. Geological Survey Water-Resources Investigations Report 86-4113, 244 p.

12. Jiracek, G.R., 1982, Geophysical evaluation of basin hydrologic characteristics in the central Rio Grande Rift, part 3, Electrical resistivity investigations: University of New Mexico contract no. 1408000117879,109 p.

13. Kaehler, C.A., 1990, Lithology of basin-fill deposits in the Albuquerque-Belen Basin, New Mexico: U.S. Geological Survey Water-Resources Investigations Report 89-4162, 17 p.

14. Kentron International, Inc., 1980, Revised three-dimensional water resources flow model: Contract no. GS07502355, Task 80-001, 39 p.

15. Kernodle, J.M., in press, Summary of U.S. Geological Survey ground-water flow models of basin-alluvial aquifers in the Southwest alluvial basins region, Colorado, New Mexico, and Texas: U.S. Geological Survey Professional Paper 1407-B.

16. Kernodle, J.M., Miller, R.S., and Scott, W.B., 1987, Three-dimensional digital computer model of transient ground-water flow in the Albuquerque-Belen Basin, New Mexico: U.S. Geological Survey Water-Resources Investigations Report 86-4194, 86 p.

17. Kernodle, J.M., and Scott, W.B., 1986, Three-dimensional simulation of steady-state ground-water flow in the Albuquerque-Belen Basin, New Mexico: U.S. Geological Survey Water-Resources Investigations Report 84-4353, 58 p.

18. Miller, R.S., 1988, Users guide for RIV2--a package for routing and accounting of river discharge for a modular three-dimensional, finite-difference ground-water flow model, U.S. Geological Survey Open-File Report 88-345, 33 p.

19. O'Brien, K.M., and Stone, W.J., 1981, Water-level data compiled for hydrogeologic study of Animas Valley, Hidalgo County, New Mexico: New Mexico Bureau of Mines and Mineral Resources Open-File Report 130, 55 p.

20. 1982a, Drill hole and testing data compiled for hydrogeologic study of Animas Valley, Hidalgo County, New Mexico: New Mexico Bureau of Mines and Mineral Resources Open-File Report $132,79 \mathrm{p}$. 
21. 1982b, Water-quality data compiled for hydrogeologic study of Animas Valley, Hidalgo County, New Mexico: New Mexico Bureau of Mines and Mineral Resources Open-File Report $131,25 \mathrm{p}$.

22. 1983, A two-dimensional hydrologic model of the Animas Valley, Hidalgo County, New Mexico: New Mexico Bureau of Mines and Mineral Resources Open-File Report 133, 60 p.

23. Stone, W.J., and Mizell, N.H., 1979, Availability of geological and geophysical data for the eastern half of the U.S. Geological Survey's Southwest alluvial basins regional aquifer study: New Mexico Bureau of Mines and Mineral Resources Open-File Report 109, 80 p.

24. Uitti, P.B., 1980, Interpretation of seismic reflection data from southern San Luis Valley, south-central Colorado: Golden, Colorado, Colorado School of Mines, Master of Science Thesis.

25. Wilkens, D.W., 1984, Geology and hydrology of the Rio Grande Rift area, in Replogle, J.A., and Renard, K.G., eds., Water Today and Tomorrow: American Society of Civil Engineers Irrigation and Drainage Division Specialty Conference, Flagstaff, Ariz., 1984, Proceedings, p. 606-613.

26. 1986a, Southwest alluvial-basin regional aquifer-systems study in parts of Colorado, New Mexico, and Texas, in Sun, R.J., ed., Regional Aquifer-System Analysis Program of the U.S. Geological Survey--summary of projects, 1978-84: U.S. Geological Survey Circular 1002, p. $107-115$.

27. 1986b, Geohydrology of the Southwest alluvial basins, regional aquifer-system analysis in parts of Colorado, New Mexico, and Texas: U.S. Geological Survey WaterResources Investigations Report 84-4224, 61 p.

28. 1987, Characteristics and properties of the basin-fill aquifer determined from three test wells west of Albuquerque, Bernalillo County, New Mexico: U.S. Geological Survey Water Resources Investigations Report 86-4187, 78 p.

29. Wilkins, D.W., Scott, W.B., and Kaehler, C.A., 1980, Planning report for the Southwest alluvial basins (east) regional aquifer-system analysis in parts of Colorado, New Mexico and Texas: U.S. Geological Survey Open-File Report 80-564, 39 p.

30. Williams, R.S., Jr., and Hammond, S.E., 1989, Selected water-quality characteristics and flow of ground water in the San Luis basin, including the Conejos River subbasin, Colorado and New Mexico: U.S. Geological Survey Water-Resources Investigations Report 89-4040, 43 p.

The study in southern and central Arizona and parts of California, Nevada, and New Mexico includes an area of about 82,000 square miles and contains 72 basins that generally are separate hydrologic entities. This study involved two phases of activities; phase I study was completed in 1985 and phase II in 1990. The boundaries between basins generally correspond to surface-water drainage divides, ground-water divides, or areas of minimal interbasin connection. The study area is characterized by sharply rising mountains that separate wide, flat basins filled with varying amounts of alluvial deposits. These alluvial deposits form the major aquifers and store large amounts of water.

The basins were formed 10 to 15 million years ago when movement along high-angle normal faults down-dropped the basins in relation to the mountain masses. The result was a series of generally northwest-trending basins. The formation of basins was a gradual process that was 
accompanied by deposition of locally derived sediments. The alluvial deposits range in thickness from a few thousand feet to more than 10,000 feet. In almost all basins, the general vertical sequence of sedimentary units is, in ascending order, sediments deposited before the formation of the Basin and Range topography, lower basin and upper basin fill, and stream alluvium. Each of the hydrogeologic units has different physical, geologic, and hydrologic properties largely because of differences in the depositional environment and source area of the sedimentary material.

The basins were grouped into five categories on the basis of geologic and hydrologic properties. The groups are: (1) southeast, (2) central, (3) west, (4) Colorado River, and (5) highland. The character of the sediments filling the basins and the important flow components are similar within a group. Computer models were used to analyze ground-water flow conditions for selected basins in each group.

During the regional aquifer-system analysis study of the alluvial basins in southern and central Arizona two field observations were intensively studied (phase II study). The first observation is that in certain basins earth fissures are caused by land subsidence in response to water-level declines from pumping ground-water. Earth fissures create problems in maintenance of structures, canals, roads, and irrigation and drainage systems. Determination of the cause-andeffect relationship between ground-water pumping and fissure formation is critical to management of ground-water resources. The second observation is that the geochemical evolution of ground water in those basins has many unique features. Computer models were developed to simulate land subsidence in response to ground-water pumping and geochemical models were developed to determine the chemical evolution of water in these basins. A total of 53 reports have been completed under this part of study as listed below. As of May 1991, additional reports resulting from the Phase II study are still in preparation or in review.

1. Anderson, T.W., 1979, Development of ground-water models of alluvial basins in southcentral Arizona: Arizona State Department of Water Resources Report 2, p. 13-17.

2. 1980, Study plan for the regional aquifer-system analysis of alluvial basins in southcentral Arizona and adjacent states: U.S. Geological Survey Open-File Report 80-1197, 22 p.

3. 1983, Implications of deep percolation to ground-water systems in south-central Arizona based on numerical-model studies: Arizona State Department of Water Resources Report 4, p. 30-40.

4. 1984, Southwest alluvial basins, regional aquifer-system analysis study--an overview, in Replogle, J.A., and Renard, K.G., eds., Water Today and Tomorrow: American Society of Civil Engineers Irrigation and Drainage Division Specialty Conference, Flagstaff, Ariz., 1984, Proceedings, p. 606-613.

5.

1985, Aquifer characteristics and hydrologic processes in alluvial basins of south-central Arizona, U.S.A. in Improvement in the Use of Ground Water in Agriculture: Agriculture Engineering Technology Association of Monterrey and Mexico National Council of Science and Technology International Conference, 2nd, Torreon, Coahuila, Mexico, March 13-14, 1985, Proceedings, p. 87-104.

6. 1986a, Hydrologic setting, objectives, and approach of the Southwest alluvial basins regional aquifer-system analysis study, in Anderson, T.W., and Johnson, A.I., eds., Regional Aquifer Systems of the United States, Southwest Alluvial Basins of Arizona: American Water Resources Association Monograph Series, no. 7, p. 5-16. 
7. 1986b, Geohydrology of the Southwest alluvial basins, Arizona, in Anderson, T.W., and Johnson, A.I., eds., Regional Aquifer Systems of the United States, Southwest Alluvial Basins of Arizona: American Water Resources Association Monograph Series, no. 7, p. 99-111.

8. 1986c, Southwest alluvial basin regional aquifer-systems analysis study in southern and central Arizona and parts of adjacent States, in Sun, R.J., ed., Regional Aquifer-System Analysis Program of the U.S. Geological Survey--summary of projects, 1978-84: U.S. Geological Survey Circular 1002, p. 116-131.

9. Anderson, T.W., Freethey, G.W., and Tucci, Patrick, 1990, Geohydrology and water resources of alluvial basins in south-central Arizona and parts of adjacent states: U.S. Geological Survey Open-File Report 89-378, 99 p, pending publication as Professional Paper 1406-B.

10. Anderson, T.W., Welder, G.E., Lesser, Gustavo, and Trujillo, A., 1988, Region 7, Central Alluvial Basins, in Back, William, Rosenshein, J.S., and Seaber, P.R., eds., Hydrogeology: Boulder, Colorado, Geological Society of America, Geology of North America, v. O-2, p. 81-86.

11. Bedinger, M.S., Anderson, T.W., and Langer, W.H., 1984, Maps showing ground-water units and withdrawal, Basin and Range Province, Arizona: U.S. Geological Survey WaterResources Investigations Report 83-4114-A, scale 1:500,000, 2 sheets.

12. Briggs, P.C., and Nemecek, E.A., 1986, Technical aspects of Arizona groundwater law, in Anderson, T.W., and Johnson, A.I., eds., Regional Aquifer Systems of the United States, Southwest Alluvial Basins of Arizona: American Water Resources Association Monograph Series, no. 7, p. 93-98.

13. Carpenter, M.C., 1991, Earth-fissure movements associated with fluctuations in groundwater levels near the Picacho Mountains, south-central Arizona, 1980-84: U.S. Geological Survey Open-File Report 90-561, 64 p., pending publications as Professional Paper 437-K.

14. DeCook, K.J., and Wilson, L.G., 1980, Ground-water recharge from urban runoff and irrigation returns: Arizona State Department of Water Resources Report 1, p. 37-52.

15. Epstein, V.J., 1987, Hydrologic and geologic factors affecting land subsidence near Eloy, Arizona: U.S. Geological Survey Water-Resources Investigations 87-4143, 28 p.

16. Evans, L.G., and Haimson, J.S., 1982, SWAB/RASA aquifer parameter study: Arizona State Department of Water Resources, final report for U.S. Geological Survey contract no. 14-08-0001-18268, 21 p.

17. Fennessy, P.J., Carter, K.G., and Keith, S.J., 1980, Summary of literature information on recharge in arid-semiarid basins: University of Arizona Water Resources Research Center Report, $259 \mathrm{p}$.

18. Fields, R.L., 1986, Data-processing activities of the Southwest alluvial basins regional aquifer-system analysis study, in Anderson, T.W., and Johnson, A.I., eds., Regional Aquifer Systems of the United States, Southwest Alluvial Basins of Arizona: American Water Resources Association Monograph Series, no. 7, p. 17-24.

19. Fields, R.L., and Vetter, E.F., 1984, A data-management system for use in a ground-water modeling and resources evaluation environment: U.S. Geological Survey Water-Resources Investigations Report 84-4014, 227 p. 
20. Freethey, G.W., 1982, Hydrologic analysis of the upper San Pedro Basin from the MexicoUnited States International Boundary to Fairbank, Arizona: U.S. Geological Survey Open-File Report 82-752, 64 p.

21. 1984, Ground-water modeling, alluvial basins of Arizona, in Replogle, J.A., and Renard, K.G., eds., Water Today and Tomorrow: American Society of Civil Engineers Irrigation and Drainage Division Specialty Conference, Flagstaff, Ariz., 1984, Proceedings, p. 675-682.

22. 1986, Considerations in modeling ground-water flow in the alluvial basins of Arizona, in Anderson, T.W., and Johnson, A.I., eds., Regional Aquifer Systems of the United States, Southwest Alluvial Basins of Arizona: American Water Resources Association Monograph Series, no. 7, p. 57-68.

23. Freethey, G.W., and Anderson, T.W., 1986, Predevelopment hydrologic conditions in the alluvial basins of Arizona and adjacent parts of California and New Mexico: U.S. Geological Survey Hydrologic Investigations Atlas HA-664, scale 1:500,000, 3 sheets.

24. Freethey, G.W., Anderson, T.W., and Tucci, Patrick, 1986, Generalized distribution of aquifer lithology in the alluvial basins of Arizona and adjacent parts of California and New Mexico: U.S. Geological Survey Hydrologic Investigations Atlas HA-663, scale 1:500,000, 4 sheets.

25. Hem, J.D., and Robertson, F.N., 1987, Hydrogeochemistry of ground-water recharge in alluvial aquifers, southern Arizona, in Let's Get Moving: Salt River Project Symposium on Artificial Recharge of Ground Water in Arizona, 3rd, Tempe, Arizona, May 20-21, 1987, Proceedings, p. 30-47.

26. Keith, S.J., Paylore, Patricia, DeCook, K.J., and Wilson, L.G., 1982, Bibliography on ground-water recharge in arid and semiarid areas: University of Arizona Water Resources Research Center Report, 149 p.

27. Kisser, K.G., and Haimson, J.S., 1981, Estimations of aquifer characteristics using drillers' logs: Arizona Section of the American Water Resources Association and Hydrology Section of the Arizona-Nevada Academy of Science, Tucson, Ariz., May 1-2, 1981, Proceedings, v. 11, p. $112-116$.

28. Langer, W.H., Mulvihill, D.A., and Anderson, T.W., 1984, Maps showing ground-water levels, springs, and depth to ground water, Basin and Range Province, Arizona: U.S. Geological Survey Water Resources Investigations Report 83-4114-B, scale 1:500,000, 2 sheets.

29. Leake, S.A., 1990, Interbed storage changes and compaction in models of regional groundwater flow: Water Resources Research, v. 26, no. 9, p. 1939-1950.

30. 1990, Applications of user-supplied transformations in computer-graphics programs, in Wiltshire, D.A., Selected Papers in the Applied Computer Sciences, 1990: U.S. Geological Survey Bulletin 1908, p. A1-A5.

31. 1991, Simulation of vertical computation in models of regional ground-water flow, in Johnson, A.I., ed., Land Subsidence: International Symposium on Land Subsidence, 14th, May 1991, Houston, Texas, International Association of Hydrological Sciences Publication 200, p. 565-574. 
32. Leake, S.A., and Prudic, D.E., 1990, Documentation of a computer program to simulate aquifer-system compaction using the modular finite-difference ground-water flow model:

U.S. Geological Survey Techniques of Water Resources Investigations, book 6, chap. A2, 68 p.

33. Oppenheimer, J.M., and Sumner, J.S., 1980, Regional geophysics assessment of Southwest alluvial basins: University of Arizona, final report for U.S. Geological Survey contract no. $14-08-0001-18228,50 \mathrm{p}$.

34. 1981, Gravity modeling of the basins in the Basin and Range Province, Arizona: Arizona Geological Society Digest, v. XIII, p. 111-115.

35. Pool, D.R., 1984, Aquifer geology of alluvial basins of Arizona, in Replogle, J.A., and Renard, K.G., eds., Water Today and Tomorrow: American Society of Civil Engineers Irrigation and Drainage Division Specialty Conference, Flagstaff, Arizona, 1984, Proceedings, p. 683-690.

36. 1986, Aquifer geology of alluvial basins of Arizona, in Anderson, T.W., and Johnson, A.I., eds., Regional Aquifer Systems of the United States, Southwest Alluvial Basins of Arizona: American Water Resources Association Monograph Series, no. 7, p. 25-36.

37. 1987, Geohydrology of McMullen Valley, west-central Arizona: U.S. Geological Survey Water-Resources Investigations Report 87-4041, 51 p.

38. Robertson, F.N., 1984, Solubility controls of fluorine, barium, and chromium in ground water in alluvial basins of Arizona, in Hitchon, Brian, and Wallick, E.I., eds., Practical Applications of Ground Water Geochemistry: National Water Well Association Canadian/ American Conference on Hydrogeology, 1st, Banff, Alberta, Canada, June 22-26, 1984, Proceedings, p. 96-102.

39. 1986, Occurrence and solubility controls of trace elements in ground water in alluvial basins of Arizona, in Anderson, T.W., and Johnson, A.I., eds., Regional Aquifer Systems of the United States, Southwest Alluvial Basins of Arizona: American Water Resources Association Monograph Series, no. 7, p. 69-80.

40 . 1989, Arsenic in ground water under oxidizing conditions, southwest United States: Society for Environmental Geochemistry and Health Journal of Environmental Geochemistry and Health, v. 11 , no. $3 / 4,1989$, p. 171-185.

41. 1990, Ground-water geochemistry and information transfer in alluvial basins in Arizona, in Simpson, E.S., and Sharp, J.M., eds., Selected Papers on Hydrogeology: International Association of Hydrogeologists International Geological Congress, 28th, Proceedings, July 9 - 19, 1989, v. 1, p. 223-236.

42. 1991, Geochemistry of ground water in alluvial basins of Arizona and adjacent parts of Nevada, New Mexico and California: U.S. Geological Survey Professional Paper 1406-C, 90 p.

43. Robertson, F.N., and Garrett, W.B., 1988, Distribution of fluoride in the ground water in alluvial basins of Arizona and adjacent parts of California, Nevada, and New Mexico:

U.S. Geological Survey Hydrologic Investigations Atlas HA-665, scale 1:500,000, 3 sheets.

44. Schumann, H.W., Laney, R.L., and Cripe, L.S., 1986, Land subsidence and earth fissures caused by ground-water depletion in southern Arizona, in Anderson, T.W., and Johnson, A.I., eds., Regional Aquifer Systems of the United States, Southwest Alluvial Basins of Arizona: American Water Resources Association Monograph Series, no. 7, p. 81-91. 
45. Thompson, T.H., Nutter, Janet, and Anderson, T.W., 1984, Maps showing distribution of dissolved solids and dominant chemical type in ground water, Basin and Range Province, Arizona: U.S. Geological Survey Water-Resources Investigations Report 83-4114-C, scale $1: 500,000,4$ sheets.

46. 1982a, Borehole gravity surveys in basin-fill deposits of central and southern Arizona: U.S. Geological Survey Open-File Report 82-473, 23 p.

47. 1982b, Use of a three-dimensional model for the analysis of the ground-water flow system in Parker Valley, Arizona and California: U.S. Geological Survey Open-File Report 82-1006, 54 p.

48. 1984, Surface resistivity studies for water-resources investigations, near Tucson, Arizona: National Water Well Association Conference on Surface and Borehole Geophysical Methods in Ground Water Investigations, San Antonio, Tex., Feb. 7-9, 1984, Proceedings, p. 92-106.

49. 1989, Geophysical methods for water-resources studies in southern and central Arizona: Society of Engineering and Mineral Exploration Geophysicists Symposium on the Application of Geophysics to Engineering and Environmental Problems, Denver, Colorado, 1989, Proceedings, p. 368-383.

50. Tucci, Patrick, and Pool, D.R., 1986, Use of geophysics for geohydrologic studies in the alluvial basins of Arizona, in Anderson, T.W., and Johnson, A.I., eds., Regional Aquifer Systems of the United States, Southwest Alluvial Basins of Arizona: American Water Resources Association Monograph Series, no. 7, p. 37-56.

51. Tucci, Patrick, Schmoker, J.W., and Robbins, S.L., 1982, Borehole gravity surveys in basin-fill deposits of central and southern Arizona: U.S. Geological Survey Open-File Report $82-473,23$ p.

52. Wilson, L.G., DeCook, K.J., and Neuman, S.P., 1980, Regional recharge research for southwest alluvial basins: University of Arizona Water Resources Research Center Report, 389 p.

53. Winograd, I.J., and Robertson, F.M., 1982, Deep oxygenated ground water--anomaly or common occurrence?: Science, v. 216, p. 1227-1230.

\section{Upper Colorado River Basin}

The Upper Colorado River Basin has a drainage area of about 113,500 square miles in western Colorado, eastern Utah, southwestern Wyoming, northeastern Arizona, and northwestern New Mexico. The area contains a variety of landforms including rugged mountains, broad plains, deeply dissected canyons, relatively flat flood plains, and many erosional features. The area has been subjected to repeated tectonism. The predominant tectonic features are numerous basins and uplifts. The resulting structural relief is nearly 30,000 feet.

Consolidated sedimentary rocks of Paleozoic, Mesozoic, and Tertiary age attain a maximum thickness of tens of thousands of feet. Those rocks include fractured limestone, dolomite, and sandstone aquifers. Low-permeability limestone, dolomite, shale, and evaporite deposits act as confining units. Igneous intrusive rocks are also present. They may yield water to wells but they are not regional aquifers. 
Annual precipitation ranges from about 6 inches on the plains of Utah to about 40 inches in the mountains. Precipitation, in the form of snow and rainfall, is the major source of recharge to the aquifers. Several aquifers that are deeply buried in basins are exposed on margins of uplifts, where precipitation recharges the aquifers. Some aquifers in Tertiary rocks tend to be exposed and recharged over extensive areas.

Aquifer systems in the Upper Colorado River Basin have been grouped into three major groups. In descending order, they are the: (1) Tertiary-rock aquifers, (2) Mesozoic-rock aquifers, and (3) Paleozoic-rock aquifers. Within each aquifer group, rocks are further divided into aquifers and confining units on the basis of lithology, depositional environment, and hydrologic characteristics. Twenty-five aquifers and confining units have been identified for the Upper Colorado River Basin regional aquifer system.

The Upper Colorado River Basin regional aquifer-system analysis study was started in 1981 and completed in 1989 . The purpose of the study was to obtain regional information on hydrology, geology, and water chemistry so that water resources of the Upper Colorado River Basin aquifer system could be assessed and the potential for development evaluated. The upper part of the San Juan River Basin was excluded from this study. The remaining study area includes about 100,000 square miles. The study has completed 28 reports as listed below. As of May 1991, additional reports are still in preparation or in review.

1. Chafin, D.T., and Kimball, B.H, in press, Ground-water geochemistry of the near surface Eocene Wasatch Formation, northern Green River Basin, Sublette County, Wyoming: U.S. Geological Water-Resources Investigations Report 91-4069.

2. Freethey, G.W., 1988a, Upper Colorado River Basin regional aquifer-system analysis-Mexozoic rocks in Colorado, Utah, and Wyoming, Arizona, and New Mexico in McLean, J.S., and Johnson, A.I., eds., Regional Aquifer Systems of the United States, Aquifers of the Western Mountain Area: American Water Resources Association Monograph Series, no. 14, p. 57-70.

3. 1988b, Lithologic and hydrologic properties of Mesozoic rocks in the Upper Colorado River Basin in McLean, J.S., and Johnson, A.I., eds., Regional Aquifer Systems of the United States, Aquifers of the Western Mountain Area: American Water Resources Association Monograph Series, no. 14, p. 81-100.

4. Freethey, G.W., and Cordy, G.E., in press, Geohydrology of Mesozoic rocks in the Upper Colorado River Basin, excluding the San Juan Basin in Arizona, Colorado, New Mexico, Utah, and Wyoming: U.S. Geological Survey Professional Paper 1411-C.

5. Freethey, G.W., Kimball, B.A., Wilberg, D.E., and Hood, J.W., 1988, General hydrogeology of aquifers of Mesozoic age, Upper Colorado River Basin--excluding the San Juan Basin--in Colorado, Utah, Wyoming, and Arizona: U.S. Geological Survey Hydrologic Investigations Atlas HA-698, scale 1:2,500,000 and 1:5,000,000, 2 sheets.

6. Geldon, A.L., 1986, Hydrostratigraphic characterization of Paleozoic formations in northwestern Colorado, in Stone, D.L., ed., New Interpretations of Northwest Colorado Geology: Rocky Mountain Association of Geologists Guidebook, p. 265-281.

7. 1988a, Hydrostratigraphic characterization of Paleozoic formations in the Upper Colorado River Basin, Arizona, Colorado, New Mexico, Utah, and Wyoming, in McLean, J.S., and Johnson, A.I., eds., Regional Aquifer Systems of the United States, Aquifers of the Western Mountain Area: American Water Resources Association Monograph Series, no. 14, p. 135-159. 

$1989 \mathrm{~b}$, Porosity and permeability of the Paleozoic rocks in the Upper Colorado River Basin, Arizona, Colorado, New Mexico, Utah, and Wyoming, in McLean, J.S., and Johnson, A.I., eds., Regional Aquifer Systems of the United States, Aquifers of the Western Mountain Area: American Water Resources Association Monograph Series, no. 14, p. 171-190.

9. Kimball, B.A., 1984, Ground water age determinations, Piceance Creek Basin, Colorado: National Water Well Association Canadian/American Conference on Hydrology, 1st, Banff, Alberta, Canada, June 22-26, 1984, Proceedings, p. 267-283.

10. 1988, Geochemistry of water associated with Navajo Sandstone aquifer, San Rafael Swell area, Utah in McLean, J.S., and Johnson, A.I., eds., Regional Aquifer Systems of the United States, Aquifers of the Western Mountain Area: American Water Resources Association Monograph Series, no. 14, p. 121-134.

11. Lindner-Lunsford, J.B., Kimball, B.A., Chafin, D.T., and Bryant, C.G., 1989, Hydrogeology of aquifers of Paleozoic age, Upper Colorado River Basin--excluding the San Juan Basin--in Colorado, Utah, Wyoming, and Arizona: U.S. Geological Survey Hydrologic Investigations Atlas HA-702, scale 1:2,500,000 and 1:5000,000, 2 sheets.

12. Taylor, O.J., and Glover, K.C., 1986, Upper Colorado River Basin regional aquifer-system study, in Sun, R.J., ed., Regional Aquifer-System Analysis Program of the U.S. Geological Survey--summary of projects, 1978-84: U.S. Geological Survey Circular 1002, p. 223-233.

13. Taylor, O.J., and Hood, J.W., 1988, Region 3, Colorado and Wyoming Basin, in Back, William, Rosenshein, J.S., and Seaber, P.R., eds., Hydrogeology: Boulder Colorado, Geological Society of America, Geology of North America: v. O-2, p. 37-50.

14. Taylor, O.J., Hood, J.W., and Zimmerman, E.A., 1983, Plan of study for the regional aquifer system analysis of the Upper Colorado River Basin in Colorado, Utah, Wyoming, and Arizona: U.S. Geological Survey Water-Resources Investigations Report 83-4184, 23 p.

15. 1986, Hydrogeologic framework of the Upper Colorado River Basin--excluding the San Juan Basin--in Colorado, Utah, Wyoming, and Arizona: U.S. Geological Survey Hydrologic Investigations Atlas HA-687, scale 1:3,000,000, 2 sheets.

16. Teller, R.W., and Chafin, D.T., 1984, Selected drill-stem test data for the Upper Colorado River Basin: U.S. Geological Survey Water-Resources Investigations Report 84-4146, 112 p.

17. Thomas, B.E., 1986, Simulation analysis of water-level changes in the Navajo Sandstone due to changes in the altitude of Lake Powell near Wahweap Bay, Utah and Arizona: U.S. Geological Survey Water-Resources Investigations Report 85-4207, 45 p.

18. 1989, Simulation analysis of the ground-water system in Mesozoic rocks in the Four Corners area, Utah, Colorado, Arizona, and New Mexico: U.S. Geological Survey WaterResources Investigations Report 88-4086, 89 p.

19. Weigel, J.F., 1987a, Selected hydrologic and physical properties of Mesozoic formations in the Upper Colorado River Basin -- excluding the San Juan Basin--in Arizona, Colorado, Utah, and Wyoming: U.S. Geological Survey Water-Resources Investigations Report 86-4170, 68 p.

20. 1987b, Selected water-level data for Mesozoic formations in the Upper Colorado River Basin, -- excluding the San Juan Basin--in Arizona, Colorado, Utah, and Wyoming: U.S. Geological Survey Open-File Report 87-397, 73 p. 
21. 1988, Sources of hydrologic data on Mesozoic formations in the Upper Colorado River Basin and comparison of data analysis methods, in McLean, J.S., and Johnson, A.I., eds., Regional Aquifer Systems of the United States, Aquifers of the Western Mountain Area: American Water Resources Association Monograph Series, No. 14, p. 71-80.

22. Weiss, Emanuel, 1985, Evaluating the hydraulic effects of changes in aquifer elevation using curvilinear coordinates: Journal of Hydrology, v. 81, p. 253-275.

23. 1986, Ground-water flow in the Navajo Sandstone in parts of Emery, Grand, Carbon, Wayne, Garfield, and Kane Counties, southeast Utah: U.S. Geological Survey Water-Resources Investigations Report 86-4012, $41 \mathrm{p}$.

24. 1987, Boundary integral-equation-method modeling of a regional aquifer using geostatistics: National Water Well Association Solving Ground Water Problems With Models Conference and Exposition, February 10-12, 1987, Denver, Colorado, Proceedings v. 2, p. $1501-1522$.

25. 1990a, Evaluating the hydraulic effects of aquifer folds: New Jersey, Gulf Publishing Encyclopedia of Fluid Mechanics, chapter 8, v. 10, Subsurface and Ground Water Flow Phenomena, p. 295-326.

26. 1990b, Comparison of Darcian flow in corresponding flat and folded surfaces:

Water Resources Research, v. 26, no. 8, p. 1775-1785.

27. ___ in press, Regional ground-water flow in Upper and Middle Paleozoic rocks in southeastern Utah and adjacent Parts of Arizona, Colorado, and New Mexico: U.S. Geological Survey Water Resources Investigations Report 90-4079.

28. Wetherbee, G.A., Van Liew, W.P., 1988, Geophysically determined porosity of Paleozoic rocks in the Upper Colorado River Basin, in McLean, J.S., and Johnson, A.I., eds., Regional Aquifer Systems of the United States, Aquifers of the Western Mountain Area: American Water Resources Association Monograph Series, no. 14, p. 161-169. 



\section{ONGOING REGIONAL AQUIFER-SYSTEM ANALYSIS STUDIES}

\section{Appalachian Valleys and Piedmont}

The study area of the Appalachian Valleys and Piedmont regional aquifer-system analysis (APRASA) is about 145,000 square miles, covering parts of New Jersey, Pennsylvania, Delaware, Maryland, the District of Columbia, West Virginia, Virginia, Tennessee, North Carolina, South Carolina, Georgia, and Alabama. The study area lies within parts of the Valley and Ridge, Blue Ridge, and Piedmont physiographic provinces in the Appalachian Highlands of the eastern United States. The Valley and Ridge physiographic province is a belt averaging about 50 miles in width and extending about 1,000 miles along the northwestern edge of the study area from near Scranton, Pennsylvania, southwestward to Birmingham, Alabama, including an area of about 48,000 square miles. The topography of the province consists of low undulating hills near the northeastern and southwestern ends of the province, then rises to low mountains in Pennsylvania, Virginia and West Virginia. Most of the Valley and Ridge physiographic province contains more than a dozen major northeast-trending valleys and ridges. Mean land surface elevation ranges between 600 and 1,500 feet above sea level.

The southeastern edge of the study area lies within the Piedmont physiographic province, and extends approximately 1,000 miles from near New York City to near Montgomery, Alabama. In New Jersey, the Piedmont province is less than 40 miles wide, but in North Carolina, it has a width of about 150 miles. The topography of the province consists of low, well-rounded hills and plains with high hills. The surfaces of many hill tops and interstream divides are relatively flat. Erosion by streams has dissected the Piedmont and created local topographic reliefs of 100 to 200 feet between drainage divides and stream bottoms. Land-surface elevation of the Piedmont area ranges from 300 to 600 feet above sea level along the eastern boundary with the coastal plain (termed the Fall Line), to more than 1,500 feet near the escarpment of the Blue Ridge.

The Blue Ridge physiographic province is a belt of low, rugged mountains that lies between the Valley and Ridge Province on the west and Piedmont on the east. It extends from a narrow section in southern Pennsylvania to a wide section in Georgia, passing through North Carolina and eastern Tennessee where it is nearly 100 miles wide. The Blue Ridge province contains the highest mountains in the eastern United States with elevations of the highest peaks more than 6,000 feet above sea level. The area of the Piedmont and Blue Ridge physiographic provinces combined is about 95,000 square miles.

Geologically and structurally, the study area can be divided into two distinct hydrogeological areas. The first area includes the Valley and Ridge physiographic province and the extreme western part of the Blue Ridge physiographic province. This area mostly consists of Paleozoic carbonate rocks (dolomite and limestone), sandstone, siltstone and shale. Ground-water flow in these rocks is predominantly through fractures or solution channels. The second area includes the Piedmont physiographic province and a larger part of the Blue Ridge physiographic province where often highly deformed Precambrian and lower Paleozoic metamorphic rocks are intruded by granite or other igneous intrusions. Ground-water flow in these rocks is predominantly through fractures that tend to decrease in openings and numbers with depth but may extend several hundreds or thousands of feet down into the rocks. Approximately 15 large rift basins, locally called early Mesozoic basins, are filled with sedimentary rocks intruded with basaltic lava flows. These basins occur within a 600 mile long area of the Piedmont. Permeability of the sandstones and other continental deposits is mostly in primary pore spaces but fractures, joints, and bedding planes are additional avenues for ground water flow. Ground water is stored mostly in the regolith that mantles the fractured rocks in these physiographic provinces. The 
regolith includes soil, saprolite and partly weathered rocks. The thicker the regolith, the greater is the storage capacity of the ground water.

The APRASA is one of the few RASA studies that deals with numerous, discrete aquifers of limited areal extent; thus the study approach is different from that of most of the other RASA studies. Two or three small areas within each physiographic province have been selected for study. These smaller study areas are termed "type areas". These "type-area" studies are for the purpose of defining relations between: (1) streamflow and ground-water discharge, (2) distribution and quantity of recharge and discharge, (3) regolith thickness and ground-water availability, (4) ground-water flow characteristics and fracture or solution channel permeability, and (5) chemical evolution of water quality as related to the ground-water flow system and rock mineralogy, as well as the quantity and quality of ground water in the type areas. The results from the "type areas" study can be transferred to many similar areas within the Appalachian Valleys and Piedmont area.

The APRASA study was started in 1988 and is scheduled for completion in 1993. As of March 1991, the study has completed 5 reports as listed below.

1. Daniel, C.C., III, and Payne, R.A., 1990, Hydrogeologic unit map of the Piedmont and Blue Ridge provinces of North Carolina: U.S. Geological Survey Water-Resources Investigations Report 90-4035, scale 1:500,000.

2. Hollyday, E.F., and Smith, Mark A., 1990, Large springs in the Valley and Ridge Province in Tennessee: U.S. Geological Survey Water-Resources Investigations Report 89-4205, 9 p.

3. Knopman, D.S., 1991, Factors controlling water-yielding potential of rocks in the Piedmont, and Valley and Ridge provinces of Pennsylvania: U.S. Geological Survey Water-Resources Investigations Report 90-4174, 52 p.

4. Saad, D.A., and Hippe, D.J., 1990, Large springs in the Valley and Ridge physiographic province of Pennsylvania: U.S. Geological Survey Open-File Report 90-164, 17 p.

5. Seaber, P.R., Brahana, J.V., and Hollyday, E.F., 1988, Region 20, Appalachian Plateaus and Valley and Ridge, in Back, William, Rosenshein, J.S., and Seaber, P.R., eds., Hydrogeology: Boulder, Colorado, Geological Society of America, Geology of North America, v. 0-2, p. 189-200.

\section{Edwards-Trinity Aquifer System, Arkansas, Oklahoma, and Texas}

The approximately 95,000-square-mile study area of the Edwards-Trinity regional aquifer-system analysis study consists of the Edwards-Trinity aquifer system of central Texas, southeastern Oklahoma, and southwestern Arkansas, plus contiguous hydraulically-connected units. The Edwards-Trinity aquifer system includes three major aquifers that occur in rocks of Cretaceous age. The three aquifers of the system, named the Edwards aquifer, the Trinity aquifer, and the Edwards-Trinity aquifer, together extend over an area of about 80,000 square miles. The Edwards aquifer is composed mostly of extensively fractured and solutioned limestone that yields large quantities of water to wells and springs. The Trinity aquifer consists primarily of dolomitic limestone with interbedded sand, shale, and clay; and the Edwards-Trinity aquifer generally is composed of limestone and dolomite in its upper part, and quartz-rich sand in its lower part. These aquifers are laterally adjacent except in the southwestern part of the system where part of the Trinity aquifer is overlain by the Edwards aquifer. 
In the southern half of the study area, south and west of the Colorado River, much of the aquifer system is near the surface and unconfined. An exception is the area at the southeastern fringe of the system where it is buried and confined. In the northern half of the study area, the aquifer system crops out in a band along its western and northern boundary, and becomes buried and confined in its eastern part.

During the late 1980 's, an estimated 1,200,000 acre-feet per year of water was withdrawn from the study area for all uses. More than 80 percent of the withdrawals $(1,000,000$ acre-feet per year) occurred in the southern one-half of the study area. Within that area, the major withdrawals are concentrated in the highly productive Edwards aquifer, which underlies an area of approximately 3,000 square miles. An estimated 545,000 acre-feet of water was withdrawn from the Edwards in 1988, primarily to supply municipal and industrial water to the San Antonio metropolitan area and irrigation water to farms west of the San Antonio area. Nearly about onehalf of the ground-water supplies were withdrawn from about 3 percent of the study area.

Extensive development of ground water has occurred in parts of the Edwards-Trinity aquifer and Trinity aquifer also; but these aquifers are much less productive than the Edwards. About 130,000 acre-feet of water was withdrawn from the Edwards-Trinity aquifer and contiguous hydraulically connected units in 1989 for irrigation in two adjacent counties in the westernmost part of the southern study area. In the northern study area, concentrated withdrawals from the Trinity aquifer for municipal and industrial use occur in the Dallas-Fort Worth area. In 1988, about 75,000 acre-feet was withdrawn in the nine-county Greater Dallas-Fort Worth area. Surface water must supply the major water needs of the area because of the relatively low water-yielding potential of the Trinity aquifer.

Among water issues affecting the aquifer system, one issues overshadows all others. That issue is the long-term capability of the Edwards aquifer to continuously supply all water needed by the Greater San Antonio area. Large transmissivity values (about 200,000 to 2,000,000 square feet per day), together with the capacity to accept plentiful recharge during wet periods, have thus far kept the Edwards from experiencing a long-term loss of water in storage. But the aquifer has become more susceptible in drought in recent years. Increasingly large withdrawals have caused an increase in short-term water-level decline in the San Antonio area.

The Edwards-Trinity regional aquifer-system analysis study began in 1986 and is scheduled for completion in 1993. The objectives of the study are to define the hydrogeologic framework, describe the geochemistry and ground-water flow in the aquifer system, and provide an understanding of the system's long-term potential for development. As in most regional aquifer-system analysis studies, a multidisciplinary approach is being used in which computer simulation of ground-water flow is one of the principal methods of investigations. The study has completed six reports as listed below.

1. Barker, R.A., and Ardis, A.F., in press, Configuration of the base of the Edwards-Trinity aquifer system and hydrogeology of the underlying pre-Cretaceous rocks, west-central Texas: U.S. Geological Survey Water-Resources Investigations Report 91-4071.

2. Bush, P.W., 1986, Planning report for the Edwards-Trinity regional aquifer-system analysis in central Texas, southeast Oklahoma, and southwest Arkansas: U.S. Geological Survey WaterResources Investigations Report 86-4343, 15 p.

3. Kuniansky, E.L., 1989, Precipitation, streamflow, and base flow in west-central Texas, December 1974 through March 1977: U.S. Geological Survey Water-Resources Investigations Report 88-4218, 2 over-size sheets. 
4. 1990a, A finite-element model for simulation of two-dimensional steady-state flow in confined aquifers: U.S. Geological Survey Open-File report 90-187, 77 p.

5. 1990b, Potentiometric surface of the Edwards-Trinity aquifer system and contiguous hydraulically connected units, west-central Texas, winter 1974-75: U.S. Geological Survey Water-Resources Investigations Report 89-4208, scale 1:750,000, 2 sheets.

6. Lurry, D.L., and Pavlicek, D.J., in press, Withdrawals from the Edwards-Trinity aquifer system and contiguous hydraulically connected units, west-central Texas, December 1974 through March 1977: U.S. Geological Survey Water-Resources Investigations Report 91-4021.

\section{Gulf Coastal Plain}

The Gulf Coastal Plain regional aquifer-system analysis study covers an area of about 230,000 square miles onshore in parts of Alabama, Arkansas, Florida, Illinois, Kentucky, Mississippi, Missouri, Tennessee, Texas, and all of Louisiana. The study area also includes 60,000 square miles offshore between the coast and the edge of the continental shelf. The study is limited to the coastal plain sediments of Tertiary and younger age except for an area in the Mississippi embayment where Upper Cretaceous sediments supply ground water in parts of several States. The bottom of the aquifer system is specified at either the top of the Paleocene Midway Group that consists of low permeable sediments, or at the top of geopressured zones. The sediments are thin in and near the outcrop areas but attain thicknesses of several thousand feet downdip. None of the individual aquifers are continuous throughout the study area; some cover only a few hundred square miles. Some of the aquifers in sediments of Eocene age are present in as many as 8 of the 10 States and supply large quantities of fresh water for municipal, industrial, and agricultural use.

The sediments within the study area are composed predominantly of alternating beds of sand and clay with some interbedded gravel, silt, lignite, and limestone. The sediments that comprise the individual aquifers and associated confining units are exposed at land surface in narrow bands several miles wide that roughly parallel the present Gulf of Mexico coastline or the axis of major embayments. The sediments in the study area generally dip toward the Gulf of Mexico and generally become thicker and less permeable downdip. The regional ground-water flow pattern in these sediments is interrupted downdip by faulting or by the geopressured zone.

On the basis of differences in regional ground-water flow patterns and sediment characteristics, three aquifer systems have been delineated in sediments of the Gulf Coastal Plain--the Mississippi embayment aquifer system, the Texas coastal uplands aquifer system, and the coastal lowlands aquifer system. These three regional aquifer systems have been developed to produce water for municipal, industrial, and agricultural use to varying degrees throughout the area. A variety of problems have resulted from development: (1) movement of saltwaterfreshwater interfaces into parts of aquifers that previously contained freshwater; (2) lowering of the potentiometric surface; and (3) land subsidence due to compaction of clay within the aquifer system.

The Gulf Coastal Plain regional aquifer-system analysis study was started in 1980 and is scheduled for completion in 1991. Its objectives are to: (1) define the geohydrologic framework of the aquifers; (2) describe the chemistry of the ground water, (3) analyze the regional groundwater flow patterns, and (4) evaluate the potential for compaction of confining units resulting from changes in fluid pressures. Computer models have been used to simulate the ground-water flow and test hypotheses about characteristics of the aquifer system. Most of the project activities have 
been completed, except report preparation. As of May 1990, the study has completed 61 reports as iisted below. Additional reports are in various stages of preparation or in review.

1. Ackerman, D.J., 1987a, Generalized potentiometric surface of the aquifers in the Cockfield Formation, southeastern Arkansas, spring 1980: U.S. Geological Survey Water-Resources Investigations Report 87-4212, scale 1:500,000.

2. 1987b, Generalized potentiometric surface of the Sparta-Memphis aquifer, eastern Arkansas, spring 1980: U.S. Geological Survey Water-Resources Investigations Report $87-4282$, scale $1: 500,000$.

3. 1989a, Hydrology of the Mississippi River Valley alluvial aquifer, south-central United States--a preliminary assessment of the regional flow system: U.S. Geological Survey WaterResources Investigations Report 88-4028, 74 p.

4. 1989 b, Potentiometric surfaces of the Mississippi River Valley alluvial aquifer in eastern Arkansas, spring 1972 and 1980: U.S. Geological Survey Water-Resources Investigations Report $88-4075$, scale $1: 500,000$.

5. 1990, Hydrology of the Mississippi River Valley alluvial aquifer, south-central United States: U.S. Geological Survey Open-File Report 90-358, 115 p., pending publication as Professional Paper 1416-D.

6. Arthur, J.K., and Taylor, R.E., 1986, Mississippi embayment aquifer system in Mississippi-geohydrologic data compilation for flow model simulation: American Water Resources Association Water Resources Bulletin, v. 22, no. 6, p. 1021-1029.

7. 1990, Definition of geohydrologic framework and preliminary simulation of groundwater flow in the Mississippi embayment aquifer system, Gulf Coastal Plain, United States: U.S. Geological Survey Water-Resources Investigations Report 86-4364, 97 p.

8. Beckman, J.D., and Williamson, A.K., 1990, Salt-dome locations in the Gulf Coastal Plain, south-central United States: U.S. Geological Survey Water-Resources Investigations Report 90-4060, 44 p.

9. Boswell, E.H., and Arthur, J.K., 1988, Generalized potentiometric surface of shallow aquifers in southern Mississippi, 1982: U.S. Geological Survey Water-Resources Investigations Report 87-4257, scale 1:500,000.

10. Brahana, J.V., 1987, The role of a multilayer model in refining understanding of deep regional ground-water flow in a tectonically active area: National Water Well Association Conference on Solving Ground-Water Problems with Models, Denver, Colorado, February 10-12, 1987, Proceedings, v. 2, p. 1051-1070.

11. Brahana, J.V., and Mesko, T.O., 1988, Hydrogeology and preliminary assessment of regional flow in the Upper Cretaceous and adjacent aquifers in the northern Mississippi embayment: U.S. Geological Survey Water-Resources Investigations Report 87-4000, 65 p.

12. Brahana, J.V., Mesko, T.O., Busby, J.F., and Kraemer, T.F., 1985, Ground-water quality data from the northern Mississippi embayment--Arkansas, Missouri, Kentucky, Tennessee, and Mississippi: U.S. Geological Survey Open-File Report 85-683, 15 p. 
13. Garza, Sergio, Jones, B.D., and Baker, E.T., 1987, Approximate potentiometric surface for the aquifers of the Texas coastal uplands system, 1980: U.S. Geological Survey Hydrologic Investigations Atlas HA-704, scale 1:1,500,000.

14. Grubb, H.F., 1984, Planning report for the Gulf Coast regional aquifer-system analysis, Gulf of Mexico Coastal Plain, United States: U.S. Geological Survey Water-Resources Investigations Report 84-4291, 30 p.

15. 1985, Gulf Coast regional aquifer-system analysis--an overview, in Smerdon, E.T., and Jordan, W.R., eds., Issues in Groundwater Management: Austin, University of Texas Center for Research in Water Resources Symposium, 12th, San Antonio, Texas, October 29-31, 1984, Proceedings, p. 69-91.

16. 1986a, Gulf Coast regional aquifer-system analysis--Mississippi perspective: U.S. Geological Survey Water-Resources Investigations Report 86-4162, 22 p.

17. 1986b, Gulf Coastal Plain regional aquifer-system study, in Sun, R.J., ed., Regional Aquifer-System Analysis Program of the U.S. Geological Survey--summary of projects, 1978-84: U.S. Geological Survey Circular 1002, p. 152-161.

18. 1987, Overview of the Gulf Coast regional aquifer-system analysis, in, Vecchioli, John, and Johnson, A.I., eds., Regional Aquifer Systems of the United States, Aquifers of the Atlantic and Gulf Coastal Plain: American Water Resources Association Monograph Series, no. 9, p. 101-118.

19. Grubb, H.F., and Arthur, J.K., 1991, Gulf Coast regional aquifer-system analysis--a Kentucky perspective: U.S. Geological Survey Water-Resources Investigations Report 90-4138, 28 p.

20. Grubb, H.F., and Carrillo R., J.J., 1988, Region 23, Gulf of Mexico Coastal Plain, in Back, William, Rosenshein, J.S., and Seaber, P.R., eds., Hydrogeology: Boulder, Colorado, Geological Society of America, Geology of North America, v. O-2, p. 219-228.

21. Hosman, R.L., 1982, Outcropping Tertiary units in southern Arkansas: U.S. Geological Survey Miscellaneous Investigations Map I-1405, scale 1:250,000.

22. 1988, Geohydrologic framework of the Gulf Coastal Plain: U.S. Geological Survey Hydrologic Investigations Atlas HA-695, scale 1:2,500,000, 2 sheets.

23. 1991, Regional stratigraphy and subsurface geology of Cenozoic deposits, Gulf Coastal Plain, south-central United States: U.S. Geological Survey Open-File Report 91-66, 43 p., pending publication as Professional Paper 1416-G.

24. Hosman, R.L., and Weiss, J.S., 1988, Geohydrologic units of the Mississippi embayment and Texas coastal uplands aquifer systems, south-central United States: U.S. Geological Survey Open-File Report 88-316, 21 p., pending publication as Professional Paper 1416-B.

25. Kuiper, L.K., 1983, A numerical procedure for the solution of the steady-state variabledensity groundwater flow equation: Water Resources Research, v. 19, no. 1, p. 234-240.

26. 1985, Documentation of a numerical code for the simulation of variable density groundwater flow in three dimensions: U.S. Geological Survey Water-Resources Investigations Report 84-4302, $90 \mathrm{p}$. 
27. 1986, A comparison of several methods for the solution of the inverse problem in twodimensional steady-state groundwater flow modeling: Water Resources Research, v. 22, no. 5, p. 705-714.

28. 1987a, A comparison of iterative methods as applied to the solution of the nonlinear three-dimensional groundwater flow equation: Society of Industrial and Applied Mathematics Journal on Scientific and Statistical Computing, v. 8, no. 4, p. 521-528.

29. 1987b, Computer program for solving ground-water flow equations by the preconditioned conjugate gradient method: U.S. Geological Survey Water-Resources Investigations 87-4091, $34 \mathrm{p}$.

30. MacCary, L.M., 1984, Relationship of formation factor to depth of burial in aquifers along the Texas Gulf Coast: National Water Well Association Conference on Surface and Borehole Geophysical Methods in Ground Water Investigations, San Antonio, Texas, February 7-9, 1984, Proceedings, p. 722-742.

31. Martin, Angel, Jr., and Early, D.A., 1987, Statistical analysis of aquifer-test results for nine regional aquifers in Louisiana: U.S. Geological Survey Water-Resources Investigations Report $87-4001,26 \mathrm{p}$.

32. Martin, Angel, Jr., and Whiteman, C.D., Jr., 1985a, Map showing generalized potentiometric surface of aquifers of Pleistocene age, southern Louisiana, 1980: U.S. Geological Survey WaterResources Investigations Report 84-4331, scale 1:500,000.

33. 1985b, Map showing generalized potentiometric surface of the Evangeline and equivalent aquifers in Louisiana, 1980: U.S. Geological Survey Water-Resources Investigations Report 84-4359, scale 1:500,000.

34. 1986, Generalized potentiometric surface of the Catahoula aquifer in central Louisiana, 1980: U.S. Geological Survey Water-Resources Investigations Report 86-4059, scale 1:500,000.

35 . 1989 , Geohydrology and regional ground-water flow of the coastal lowlands aquifer system in parts of Louisiana, Mississippi, Alabama, and Florida -- a preliminary analysis: U.S. Geological Survey Water-Resources Investigations Report 88-4100, 88 p.

36. 1990, Calibration and sensitivity analysis of a ground-water flow model of the coastal lowlands aquifer system in parts of Louisiana, Mississippi, Alabama, and Florida: U.S. Geological Survey Water-Resources Investigations Report 89-4189, 54 p.

37. 1991, Hydrology of the coastal lowlands aquifer system in parts of Alabama, Florida, Louisiana, and Mississippi: U.S. Geological Survey Open-File Report 91-72, 115 p., pending publication as Professional Paper 1416- $\mathrm{H}$.

38. Martin, Angel, Jr., Whiteman, C.D., Jr., and Becnel, M.J., 1988, Generalized potentiometric surfaces of the upper and lower Jasper and equivalent aquifers in Louisiana, 1984: U.S. Geological Survey Water-Resources Investigations Report 87-4139, scale $1: 500,000,2$ sheets.

39. Mesko, T.O., 1988, Subsurface geology of Paleozoic, Mesozoic, and Cenozoic units in southeast Missouri: U.S. Geological Survey Miscellaneous Investigations Map I-1875, scale $1: 1,000,000,3$ sheets. 
40. 1990, Geohydrology and water quality of Mesozoic and Cenozoic units in southeast Missouri: U.S. Geological Survey Hydrologic Investigations Atlas HA-719, scale 1:1,000,000, 2 sheets.

41. Mesko, T.O., Williams, T.A., Ackerman, D.J., and Williamson, A.K., 1990, Groundwater pumpage from the Gulf Coast aquifer system, 1960-85, south-central United States: U.S. Geological Survey Water-Resources Investigations Report 89-4180, 177 p.

42. Parks, W.S., and Carmichael, J.K., 1989, Geology and ground-water resources of the Fort Pillow Sand in western Tennessee: U.S. Geological Survey Water-Resources Investigations Report 89-4120, 20 p.

43. 1990a, Geology and ground-water resources of the Memphis Sand in Western Tennessee: U.S. Geological Survey Water-Resources Investigations Report, 88-4182, 30 p.

44. $1990 \mathrm{~b}$, Geology and ground-water resources of the Cockfield Formation in western Tennessee: U.S. Geological Survey Water-Resources Investigations Report 88-4181, 17 p.

45 . 1990c, Altitude of potentiometric surface, fall 1985, and historic water-level changes in the Memphis aquifer in western Tennessee: U.S. Geological Survey WaterResources Investigations Report 88-4180, 8 p.

46. 1990d, Altitude of potentiometric surface, fall 1985, and historic water-level changes in the Fort Pillow aquifer in western Tennessee: U.S. Geological Survey WaterResources Investigations Report, 89-4048, 8 p.

47. Pettijohn, R.A., 1986, Processing water chemistry data, Gulf Coast aquifer system, southcentral United States, with a summary of dissolved-solids concentrations and water types: U.S. Geological Survey Water-Resources Investigations Report 86-4186, 42 p.

48. 1988, Dissolved-solids concentrations and primary water types, Gulf Coast aquifer system, south-central United States: U.S. Geological Survey Hydrologic Investigations Atlas HA-706, scale 1:5,000,000, 2 sheets.

49. Pettijohn, R.A., Weiss, J.S., and Williamson, A.K., 1988, Distribution of dissolved-solids concentrations and temperature in ground water of the Gulf Coast aquifer systems, south-central United States: U.S. Geological Survey Water-Resources Investigations Report 88-4082, scale $1: 3,500,000,5$ sheets.

50. Prudic, D.E., 1991, Estimates of hydraulic conductivity from aquifer-test analyses and specific capacity data, Gulf Coast aquifer systems, south-central United States: U.S. Geological Survey Water-Resources Investigations Report 90-4121, 38 p.

51. Ryder, P.D., 1988, Hydrogeology and predevelopment flow in the Texas Gulf Coast aquifer systems: U.S. Geological Survey Water-Resources Investigations Report 87-4248, 109 p.

52. Ryder, P.D., and Ardis, A.F., 1991, Hydrology of the Texas Gulf Coast aquifer systems: U.S. Geological Survey Open-File Report 91-64, 147 p., pending publication as Professional Paper 1416-E.

53. Taylor, R.E., and Arthur, J.K., 1989, Hydrogeology of the middle Wilcox aquifer system in Mississippi: U.S. Geological Survey Water-Resources Investigations Report 89-4036, scale $1: 500,000,2$ sheets. 
54. Weiss, J.S., 1987, Determining dissolved-solids concentrations in mineralized ground water of the Gulf Coast aquifer systems, using electric logs, in Vecchioli, John, and Johnson, A.I. eds., Regional Aquifer Systems of the United States, Aquifers of the Atlantic and Gulf Coastal Plain: American Water Resources Association Monograph Series, no. 9, p. 139-150.

55. 1990, Geohydrologic units of the coastal lowlands aquifer system, south-central United States: U.S. Geological Survey Open-File report 90-173, 37 p., pending publication as Professional Paper 1416-C.

56. Weiss, J.S., and Williamson, A.K., 1985, Subdivision of thick sedimentary units into layers for simulation of ground-water flow: Ground Water, v. 23, no. 6, p. 767-774.

57. Whiteman, C.D., Jr., and Martin, Angel, Jr., 1984, Geohydrologic sections, northern Louisiana: U.S. Geological Survey Water-Resources Investigations Report 84-4211, 1 over-size sheet.

58. Williams, T.A., and Williamson, A.K., 1989, Estimating water-table altitudes for regional ground-water flow modeling, U.S. Gulf Coast: Ground Water v. 27, no. 3, p. 333-340.

59. Williamson, A.K., 1987 Preliminary simulation of ground-water flow in the Gulf Coast aquifer systems, south-central United States, in Vecchioli, John, and Johnson, A.I., eds. Regional Aquifer Systems of the United States, Aquifers of the Atlantic and Gulf Coastal Plain: American Water Resources Association Monograph Series, no. 9, p. 119-137.

60. Williamson, A.K., Grubb, H.F., and Weiss, J.S., 1990, Ground-water flow in the Gulf Coast aquifer systems, south-central United States--a preliminary analysis: U.S. Geological Survey Water-Resources Investigations Report 89-4071, 124 p.

61. Wilson, T.A., and Hosman, R.L. 1988, Geophysical well-log database for the Gulf Coast aquifer systems, south-central United States: U.S. Geological Survey Open-File report 87-677, $213 \mathrm{p}$.

\section{Michigan Basin}

The Michigan basin regional aquifer-system analysis study covers about 29,000 square miles of the Lower Peninsula of Michigan. The study is limited to Mississippian and younger consolidated and unconsolidated sediments in the Michigan Basin. The Marshall Sandstone (Mississippian), sandstones within the Grand River and Saginaw Formations (Pennsylvanian), and glacial deposits (Pleistocene) are the major aquifers in the Michigan Basin. The lower limit for the study has been defined as the contact between the Coldwater Shale (Mississippian) and the overlying Marshall Sandstone. Glacial deposits overlie nearly all of the study area.

Ground water has increasingly become an important source of water in Michigan. As of 1985 , reported use of ground water averaged $220 \mathrm{Mgal} / \mathrm{d}$ (million gallons per day) for the entire State. Of this total, about $80 \mathrm{Mgal} / \mathrm{d}$ was from the Marshall and Grand River-Saginaw aquifers. About $40 \mathrm{Mgal} / \mathrm{d}$ was pumped from the glacial deposits in the study area.

The Marshall and Grand River-Saginaw aquifers are major sources of ground water for about 70 communities whose composite population is about 500,000 . The most significant problems related to ground-water supplies are the location of sufficient quantities of potable water and the upconing of saline ground water toward pumping centers. Saline water underlies the entire Lower Peninsula of Michigan. In the center of the Michigan Basin, the Marshall Sandstone 
and the deeper parts of the Saginaw Formation contain brine or saline water. In the Saginaw Lowlands, saline water is present in glacial deposits. In the Lansing area, a cone of depression that extends over 100 square miles has developed in the Grand River-Saginaw aquifer. Water levels near the center of the cone have declined about 160 feet below the prepumping level. In the Flint area, where both the Marshall and Grand River-Saginaw aquifers were used for public supply, heavy pumping caused upconing of saline water. The ground-water supply was replaced by sources of surface water.

Increased demand for ground water in Michigan is anticipated because of population growth, irrigation, and industrial development. To manage and protect the fresh ground-water resources of Michigan, an understanding of the occurrence of saline water and the relation between saline and fresh water, as well as the movement of saline water toward fresh water zone due to pumping, is necessary.

The Michigan Basin regional aquifer-system analysis study was started in 1985 and is scheduled for completion by 1993. The purpose of the study is to define the geohydrology of the sedimentary rocks and glacial deposits. The study will describe the geology of the Mississippian and younger sedimentary rocks, describe the geochemistry of ground water, delineate the interface between freshwater and saline water, and quantitatively describe the past and present groundwater flow in the study area. As of May 1991, the study has completed 10 reports as listed below.

1. Dannemiller, G.T. and Baltusis, M.A., Jr., 1990, Physical and chemical data for ground water in the Michigan Basin, 1986-1989: U.S. Geological Survey Open-File Report 90-368, 164 p.

2. Fitterman, D.F., 1986, Transient electromagnetic soundings in the Michigan Basin for ground-water evaluation: National Water Well Association Conference on Surface and Borehole Geophysical Methods and Ground Water Instrumentation, Denver, Colorado, October 15-17, 1986, Proceedings, p. 334-353.

3. Holman, A.J., Abraczinskas, L.M., and Westjohn, D.B., 1988, Pleistocene proboscideans and Michigan salt deposits: National Geographic Research, v. 4, no. 1, p. 4-5.

4. Mandle, R.J., 1986, Plan of study for the regional aquifer system analysis of the Michigan Basin: U.S. Geological Survey Open-File Report 86-494, 23 p.

5. Mandle, R.J. and Westjohn, D.B., 1987, Preliminary interpretation of vertical electricalresistivity soundings in the Saginaw Valley, Michigan: U.S. Geological Survey Open-File Report, 87-474, 45 p.

6. 1989, Geohydrologic framework and ground-water flow in the Michigan Basin, in Swain, L.A., and Johnson, A.I., eds., Regional Aquifer Systems of the United States, Aquifers of the Midwestern Area: American Water Resources Association Monograph Series, no. 13, p. $83-110$.

7. Swain, L.A., 1986, Michigan Basin regional aquifer-system study, in Sun, R. J., ed., Regional Aquifer-System Analysis Program of the U.S. Geological Survey--summary of projects, 1978-84: U.S. Geological Survey Circular 1002, p. 242-244.

8. Westjohn, D.B., 1989, Application of geophysics in the delineation of the freshwater/salinewater interface in the Michigan Basin, in Swain, L.A., and Johnson, A.I., eds., Regional Aquifer Systems of the United States, Aquifers of the Midwestern Area: American Water Resources Association Monograph Series, no. 13, p. 111-134. 
9. Westjohn, D.B. and Carter, P.J., Jr., 1989, Direct-current vertical-electrical resistivity soundings in the Michigan Basin: U.S. Geological Survey Open-File Report 89-244, 57 p.

10. Westjohn, D.B., Olsen, H.W., and Willden, A.T., 1990, Matrix-controlled hydraulic properties of Mississippian and Pennsylvanian Sandstones from the Michigan Basin: U.S. Geological Survey Open-File Report 90-104, 42 p.

\section{Ohio-Indiana Glacial and Carbonate-Rock Aquifer System}

The major aquifers of the Ohio-Indiana glacial and carbonate aquifer system include bedrock aquifers composed of Silurian and Devonian rocks, and saturated Quaternary glacial deposits. The bedrock subcrops beneath the Quaternary glacial deposits in western Ohio and eastern Indiana and receives recharge from the glacial deposits which are normally under unconfined conditions, except where outwash deposits or basal material in buried valleys are covered by till or fine-grained lake deposits. Most of the water in the glacial deposits locally discharges to streams after being recharged. However, a small amount of the recharge infiltrates downward from the glacial deposits to the underlying carbonate rocks. Water in the carbonate rocks is mostly under confined conditions, except where the bedrock is close to, or exposed at, the surface. The direction of ground-water flow in the carbonate rocks is generally toward major streams, such as the Ohio, Iroquois, Kankakee, and Scioto rivers, and to Lake Erie, and toward subcrop areas along the Scioto Valley and the Illinois structural basin.

The study area includes about 43,000 square miles and extends approximately from Columbus, Ohio, to Indianapolis, Indiana, and from Lake Erie to the Ohio River. The objectives of the study are to: (1) describe the regional ground-water flow system, including its lateral and vertical hydrologic boundaries, areas of regional recharge and discharge, and the regional relation between surface water and ground water, (2) categorize the chemistry of ground water, delineate water-chemistry patterns in major aquifers, and relate the patterns to geochemical processes and flow systems, (3) conceptualize the flow system on the basis of geohydrological and geochemical information, and (4) evaluate the potential hydrologic effects on the flow system due to development.

The study was started in 1988 and is scheduled for completion by 1993. As of March 1991, the study has completed 5 reports as listed below.

1. Bugliosi, E.F., 1989, Ohio-Indiana carbonate-bedrock and glacial regional aquifer analysis-plan of study, in Swain, L.A., and Johnson, A.I., eds., Regional Aquifer Systems of the United States, Aquifers of the Midwestern Area: American Water Resources Association Monograph Series, no. 13, p. 135-148.

2. 1990, Plan of study for the Ohio-Indiana carbonate-bedrock and glacial aquifer system: U.S. Geological Survey Open-File Report 90-151, 25 p.

3. Hackathorn, M., 1990, Research in Ohio Geology, 1988-1989: Ohio State Geological Survey Department of Natural Resources Division, $21 \mathrm{p}$.

4. Sheets, R.A., 1991, Selected geologic and hydrologic data for the regional carbonate-bedrock and glacial aquifers in western Ohio: U.S. Geological Survey Open-File Report 90-590, 43 p.

5. Strobel, M.L., and Bugliosi, E.F., in press, Areal extent, hydrogeological characteristics, and possible origins of the "Newburg Zone" in Ohio: Ohio Journal of Science. 


\section{Puget-Willamette Lowland, Washington and Oregon}

The Puget-Willamette Lowland is located in western Washington, western Oregon, and a small part of southwestern British Columbia, Canada. The study area extends from near the Fraser River in British Columbia to just south of Cottage Grove in Oregon. The Puget-Willamette Lowland consists of two distinct aquifer systems, the Puget Sound Lowland aquifer system in Washington and Canada and the Willamette Lowland aquifer system in Oregon. The study covers an area of about 27,400 square miles, of which the Puget Sound Lowland covers about 16,200 square miles (including about 2,500 square miles of saltwater area) and the Willamette Lowland is about 11,200 square miles.

Alluvium, glacial, and interglacial sediments comprise the aquifer system in the Puget Sound Lowland area. These deposits consist principally of river alluvial, recessional and advance outwash, till, and other glaciofluvial and interglacial sediments. In the Willamette Lowland, alluvium basin-fill sediments and basalt comprise the aquifer system. Tertiary sedimentary, volcanic and metamorphic rocks form the lateral and basal boundaries of both aquifer systems. About 70 percent of the population of Washington and Oregon are within the study area, mainly within the metropolitan areas of Bellingham, Everett, Seattle, Tacoma, and Olympia in the Puget Sound Lowland; and Vancouver, Portland, Salem, and Eugene in the Willamette Lowland. Recent, large increases in population are increasing the demands for water supplies. Ground water is an important source of supply in the study area, but some problems--such as saltwater intrusion from Puget Sound and upconing of salt water in the Willamette Lowland--have been associated with increases in ground-water withdrawals.

The Puget-Willamette Lowland regional aquifer-system analysis study was started in 1989 and is scheduled for completion in 1994. The objectives of the study are to: (1) describe the geohydrologic framework and hydraulic characteristics of the aquifer systems, (2) map distribution and estimate quantity of recharge and discharge, and (3) evaluate the potential effects of development on the aquifer systems. As of March 1991, the study has completed one report as listed below.

1. Jones, M.A., 1991, Selected references for the Puget-Willamette Lowland regional aquifersystem analysis, Puget Sound Lowland, Washington: U.S. Geological Survey Open-File Report 90-584, 55 p.

\section{Southern California Basins}

The regional aquifer-system analysis study of the southern California basins covers an area of 75,000 square miles. The area includes 89 drainage basins that can be grouped according to common characteristics and relations into coastal and desert basins. The objective of the study is to analyze the major problems and issues that affect the use of ground water in southern California including: (1) ground-water overdraft, (2) ground-water contamination, (3) seawater intrusion, (4) quantity and distribution of recharge, (5) inter-aquifer flow, and (6) conjunctive use of ground water and surface water. Because of the large size of the study area and the large number of basins involved, it is impractical to study these problems and issues in each basin. Therefore, selected basins will be studied to determine the major geohydrologic processes and human activities that control or influence these problems and issues. At least one coastal basin and one desert basin will be intensively studied.

The coastal basin selected for intensive study is the Santa Clara-Calleguas basin, and the desert basin is the Mojave basin. These basins are affected by all the major problems and issues 
identified for study. The intensive studies will involve assembling available geohydrologic data into a geographic information system, defining the regional geohydrology and geochemistry, and developing ground-water flow and solute-transport models to help understand the ground-water flow system. Information obtained from these intensive studies will aid in the effective management of the ground-water resources of these and other basins in southern California. The study was started in 1984, however, it was suspended immediately; and was restarted in 1990 and is scheduled for completion in 1995. As of May 1991, the study has completed two reports, as listed below.

1. Martin, Peter, 1986, Southern California alluvial basins regional aquifer-system study, in Sun, R.J., ed., Regional Aquifer-System Analysis Program of the U.S. Geological Survey--summary of projects, 1978-84: U.S. Geological Survey Circular 1002, p. 245-247.

2. Moyle, W.R., Jr., Martin, Peter, Schluter, R.C., Woolfenden, L.R., Downing, Karen, Elliott, A.L., and Maltby, D.E., 1986, Southern California alluvial basins regional aquifersystem analysis--a bibliography: U.S. Geological Survey Open-File Report 85-695, 120 p.

\section{Ground Water Atlas of the United States}

The U.S. Geological Survey has accumulated vast amounts of information and data on the Nation's ground-water conditions, including the results of the Regional Aquifer-System Analysis (RASA) Program studies. Although these large volumes of information have been published in various types of reports and scientific journal articles, however, no unified summary of groundwater conditions on a nationwide scale exists. In 1988, the U.S. Geological Survey decided to use part of the RASA resources to compile a Ground Water Atlas of the United States. The atlas will present a comprehensive summary of the Nation's ground-water resources and serve as a basic reference for the location, geography, geology, and hydrology of the major aquifers of the Nation.

The atlas, which is designed in a graphical format that is supported by descriptive discussions, will be composed of 14 chapters, or segments. One of the chapters presents an overview of the ground-water conditions, describes effects of development such as saltwater encroachment and land subsidence on the ground-water flow system, and includes two maps that show locations of major aquifers on a nationwide scale. The remaining 13 chapters describe ground-water conditions in regional segments (fig. 2). The 13 regional segments collectively cover the 50 States and Puerto Rico and describe geologic and hydrologic conditions for the major aquifers in each regional area. The scale of the atlas does not allow portrayal of local features of the geology and hydrology of the aquifers described, nor does it include discussion of minor aquifers in the region. However, readers who seek detailed, local information on specific aquifers can find extensive lists of references at the end of each chapter. The atlas is published as the U.S. Geological Survey's Hydrologic Investigations Atlas HA-730 series, with a letter A-N assigned to each chapter (fig. 2). The atlas work was started in 1988 and is scheduled for completion by 1994. As of March 1991, the atlas project has completed three reports as listed below.

1. Miller, J.A., 1990, Ground Water Atlas of the United States, Segment 6--Alabama, Florida, Georgia, and South Carolina: U.S. Geological Survey Hydrologic Investigations Atlas HA-730-G, 28 p. 
2. in press, The Ground Water Atlas of the United States--the use of specialized hydrogeologic maps to describe the Nation's major aquifers: International Association of Hydrogeologists International Conference on Groundwater in Large Sedimentary Basins, July 9-13, 1990, Perth, Australia.

3. Olcott, P.G., in press, Ground Water Atlas of the United States, Segment 9--Iowa, Michigan, Minnesota, and Wisconsin: U.S. Geological Survey Hydrologic Investigations Atlas HA-730-J.

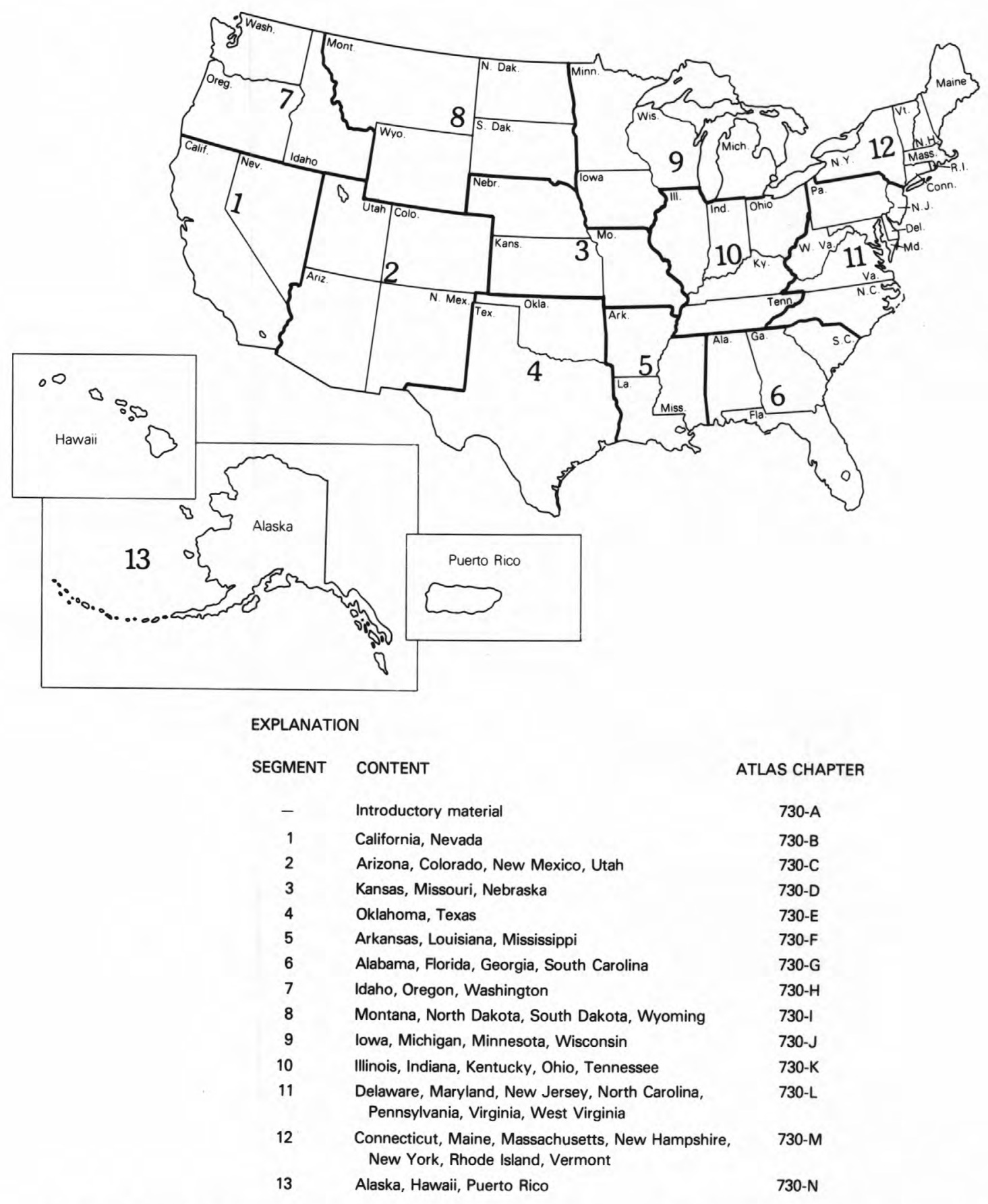

Figure 2. States contained in each segment of the Ground Water Atlas of the United States 


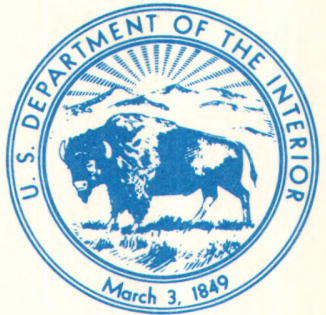

